Universidade de São Paulo

Escola Superior de Agricultura "Luiz de Queiroz"

Formação de estruturas androgenéticas por cultura de anteras de trigo em função de doses de nitrogênio e boro aplicadas às plantas doadoras

\title{
Adriano Michel
}

Tese apresentada para obtenção do título de Doutor em Ciências. Área de concentração: Fitotecnia

Piracicaba

2014 
Adriano Michel

Ciências Biológicas Licenciatura e Bacharelado

Formação de estruturas androgenéticas por cultura de anteras de trigo em função de doses de nitrogênio e boro aplicadas às plantas doadoras

versão revisada de acordo com a resolução CoPGr 6018 de 2011

Orientador:

Prof. Dr. FRANCISCO DE ASSIS ALVES MOURÃO FILHO

Tese apresentada para obtenção do título de Doutor em Ciências. Área de concentração: Fitotecnia

Piracicaba

2014 


\section{Dados Internacionais de Catalogação na Publicação DIVISÃO DE BIBLIOTECA - DIBD/ESALQ/USP}

Michel, Adriano

Formação de estruturas androgenéticas por cultura de anteras de trigo em função de doses de nitrogênio e boro aplicadas às plantas doadoras / Adriano Michel.- - versão revisada de acordo com a resolução CoPGr 6018 de 2011. - -

Piracicaba, 2014.

106 p: il.

Tese (Doutorado) - - Escola Superior de Agricultura "Luiz de Queiroz", 2014.

1. Componentes do rendimento 2. Nutrição de plantas 3. Haploide 4. Androgênese 5. Triticum aestivum L. I. Título

CDD 633.11

M623f

"Permitida a cópia total ou parcial deste documento, desde que citada a fonte -O autor" 
DEDICO

À minha família, base sólida que sustenta minhas conquistas. 


\section{AGRADECIMENTOS}

A Deus por ter dado força e saúde para seguir em frente ao longo do curso.

Ao Instituto Federal de Educação, Ciência e Tecnologia do Estado do Rio Grande do Sul - Câmpus Sertão, pela possibilidade de implantação do projeto em suas instalações e liberação das minhas atividades durante o período do estágio obrigatório.

À ESALQ/USP pela disponibilização do curso na modalidade DINTER.

Ao Centro Nacional de Pesquisa de Trigo (Embrapa Trigo) pela disponibilidade das sementes para a realização dos experimentos.

Ao professor Eng. Agro. Dr. Francisco de Assis Alves Mourão Filho pela paciência, atenção e orientação durante a execução desse trabalho.

Ao Eng. Agro. Dr. Fabiano Daniel De Bona (pesquisador da Embrapa Trigo) pelo apoio técnico-científico na execução desse trabalho.

Ao Eng. Agro. Dr. Pedro Luiz Scheeren (pesquisador da Embrapa Trigo) pelo apoio técnico-científico na execução desse trabalho.

Ao Eng. Agro. MsC. Osmar Rodrigues (pesquisador da Embrapa Trigo) pelo apoio técnico-científico na execução desse trabalho.

Ao professor Eng. Agro. Dr. Hilton Thadeu do Couto pelo auxilio nas análises estatísticas.

Ao professor Eng. Agro. Dr. Mateus Mondin e sua equipe pelo auxílio e empréstimo do laboratório de citogenética molecular de plantas.

Ao professor Eng Mec. Dr. Alan Carlos Bueno da Rocha (IFRS - Câmpus Rio Grande), pelo auxilio no desenvolvimento e construção da câmara de crescimento das plantas.

Ao meu irmão Flávio Michel pelo auxilio na construção da câmara para cultivo das plantas.

Aos professores da ESALQ/USP que participaram do programa DINTER pelos ensinamentos e compreensão ao longo do curso.

À secretária da Pós-Graduação em Fitotecnia Luciane Lopes Toledo pelo profissionalismo e solicitude em responder as demandas ao longo do curso.

À Secretária da Pós-Graduação em Fisiologia e Bioquímica de Plantas Maria Solizete Granziol Silva pelo apoio ao longo da estadia na Esalq.

À minha esposa Silvania Segati pelo apoio e compreensão ao longo do desenvolvimento do trabalho e pelo auxílio na condução dos experimentos. 
Aos colegas do IFRS - Câmpus Sertão em especial ao professor Eng. Agro. MsC Eidi Alfredo Denti pelo apoio e incentivo durante a execução dos experimentos.

À equipe do Laboratório de Cultura de Tecidos e Citogenética Vegetal do IFRS Câmpus Sertão, Bióloga MsC Carolina Binda (laboratorista) e, em especial, aos estagiários: Anderson Bertoldi, Silmar de Matos, Itamar Bonai, Léo Gustavo Cantoni e Kalan Felipe Trentin pelo apoio prestado ao longo da execução do trabalho.

À equipe do Centro de Análise de Alimentos do IFRS - Câmpus Sertão em especial a MsC. Denise Bilibio e a Biomédica Vanessa Ecléa de Oliveira, pelo auxilio prestado ao longo da realização dos experimentos.

À equipe do Laboratório de Biotecnologia Vegetal da Faculdade de Agronomia e Medicina Veterinária da Universidade de Passo Fundo (FAMV/UPF), em especial ao Sr. Clarício Machado dos Santos e a Eng. Agra ${ }^{\mathrm{a}}$ MsC. Marilei Suzin pelo apoio técnico-científico na tabulação de dados e análises citogenéticas;

À professora MsC Dileta Cecchetti pelo auxilio nas análises estatísticas;

Ao coordenador do programa DINTER no Instituto Federal Farroupilha professor Dr. Jean Karlo Acosta Mendonça pelo profissionalismo e prontidão em responder as demandas ao longo do curso.

Aos colegas de curso Cláudio Renato Schlessner, Fernando Machado dos Santos, João Flávio Carvalho, Jorge Alex Willes, Lisandra Della Flora, Luiz Alberto Cadoná, Marcelo Rodrigues, Paulo A. K. Xavier, Rosemari Kerbes Aires e Wolmar Trevisol pelo companheirismo e solidariedade ao longo do curso.

Aos colegas da pós-graduação em Fitotecnia da ESALQ/USP em especial a Meire, Filipi Augusto Coelho e Yuri Caires Ramos pelo auxilio, companheirismo e solidariedade ao longo do curso.

À empresa Adubos Coxilha LTDA, pela doação de insumos para os ensaios preliminares do experimento.

À empresa Schumacher Insumos para Indústria LTDA, pela doação do substrato (perlita expandida) para a execução dos experimentos.

À Coordenação de Aperfeiçoamento de Pessoal de Nível Superior (CAPES) pelo Projeto DINTER e pela concessão de bolsa de estudo durante o desenvolvimento do estágio na ESALQ/USP, em Piracicaba.

Enfim, a todos que de uma forma ou de outra contribuíram para a realização desse trabalho. 


\section{SUMÁRIO}

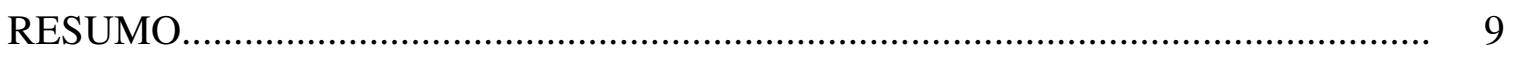

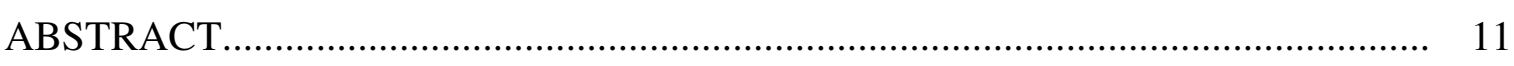

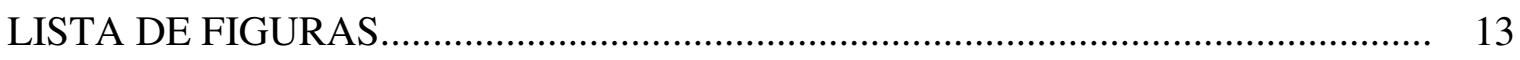

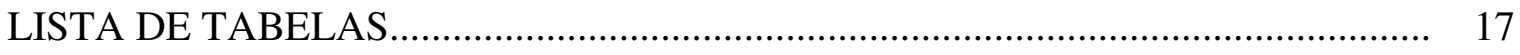

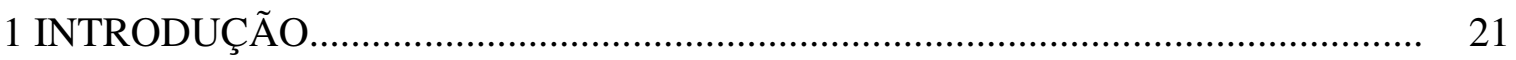

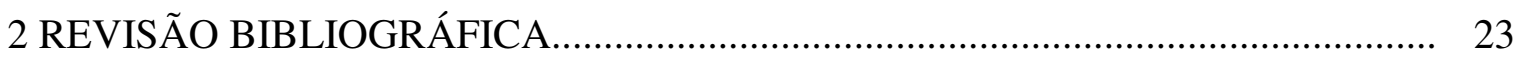

2.1 Caracterização botânica e morfofisiológica do trigo.............................................. 23

2.2 A cultura do trigo no Brasil - história e perspectivas............................................ 24

2.3 Nutrição mineral de plantas - Consideraçõoes gerais................................................ 25

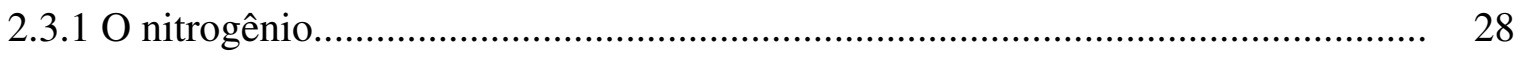

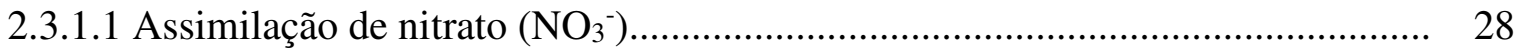

2.3.1.2 Assimilação de amônio $\left(\mathrm{NH}_{4}{ }^{+}\right)$...................................................................... 30

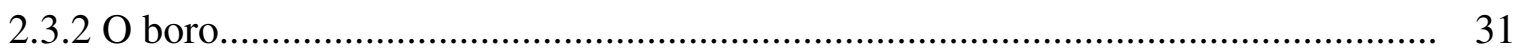

2.4 Indução do florescimento: considerações gerais................................................... 33

2.5 Biologia da formação do pólen ....................................................................... 34

2.5.1 Diferenciação dos tecidos nas anteras............................................................... 34

2.5.2 A microsporogênese .................................................................................. 35

2.5.3 A microgametogênese.......................................................................... 36

$2.6 \mathrm{O}$ melhoramento genético clássico: considerações gerais...................................... 37

2.7 Plantas haploide e duplo-haploides.................................................................... 37

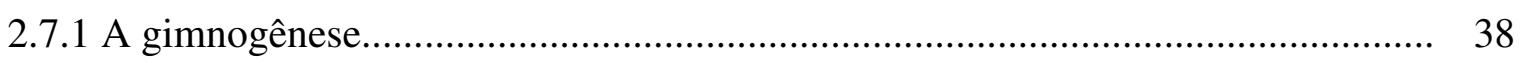

2.7.2 A androgênese e a haplodiploidização no melhoramento de plantas..................... 38

2.7.2.1 Cultivo de anteras e/ou micrósporos isolados.................................................. 41

2.7.3 Biologia da indução da androgênese.............................................................. 43

2.8 Fatores que interferem na resposta androgenética do trigo...................................... 44

2.8.1 Temperatura da câmara de crescimento das plantas doadoras das anteras........... 44

2.8.2 Intensidade luminosa da câmara de crescimento das plantas doadoras................. 45

2.8.3 Genótipo das plantas doadora de anteras e/ou micrósporos.................................. 45

2.8.4 Nutrição das plantas doadoras de anteras e/ou micrósporos................................. 45

2.8.5 Pré-tratamento de frio das anteras................................................................. 46

2.8.6 Estádio de desenvolvimento dos.micrósporos................................................ 46 
2.8.7 Meio de cultura....................................................................................... 47

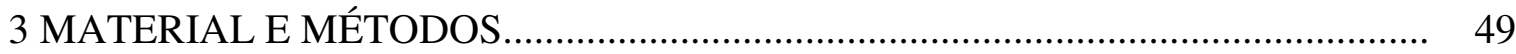

3.1 Material vegetal utilizado.................................................................................. 49

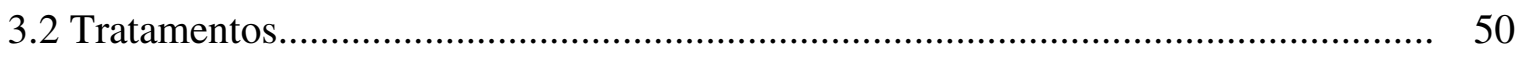

3.3 Determinação dos componentes do rendimento em trigo......................................... 51

3.4 Determinação do teor de clorofila....................................................................... 52

3.5 Determinação do acúmulo de Graus-dia (GD)..................................................... 53

3.6 Determinação do estádio de desenvolvimento dos micrósporos................................. 53

3.7 Determinação do número de estruturas embriogênicas formadas............................... 55

3.8 Meios de cultura utilizado para o cultivo das anteras de trigo................................. 55

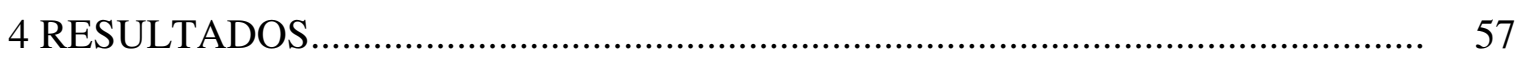

4.1 Resultados dos experimentos com cinco concentrações de nitrogênio na solução de

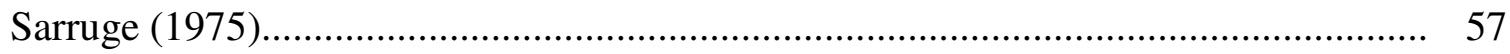

4.1.1 Componentes do rendimento........................................................................ 57

4.1.2 Determinação dos graus-dias (GD) acumulados................................................... 64

4.1.3 Determinação do estádio de desenvolvimento dos micrósporos............................. 65

4.1.4 Produção de estruturas embriogênicas androgenéticas.......................................... 68

4.2 Resultados dos experimentos com cinco concentrações de boro na solução de

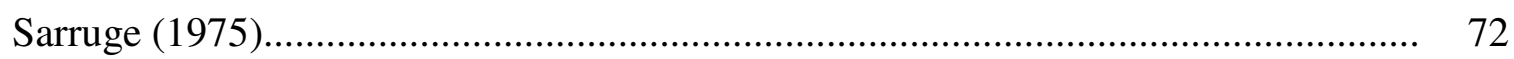

4.2.1 Componentes do rendimento........................................................................ 72

4.2.2 Determinação dos graus-dias (GD) acumulados................................................. 77

4.2.3 Determinação do estádio de desenvolvimento dos micrósporos.............................. 78

4.2.4 Produção de estruturas embriogênicas androgenéticas........................................... 80

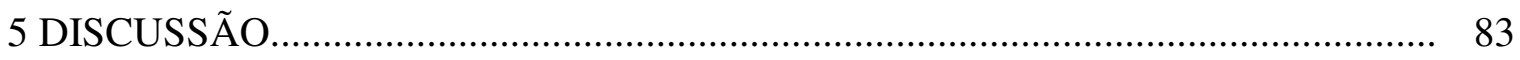

5.1 Os componentes do rendimento.................................................................... 83

$5.2 \mathrm{O}$ desenvolvimento dos micrósporos.............................................................. 87

5.3 A formação de estruturas embriogênicas androgenéticas........................................... 89

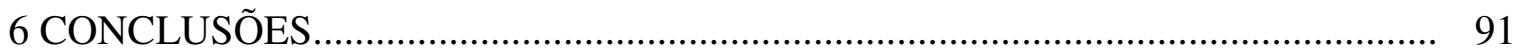

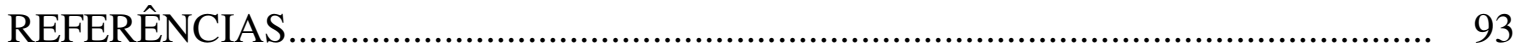

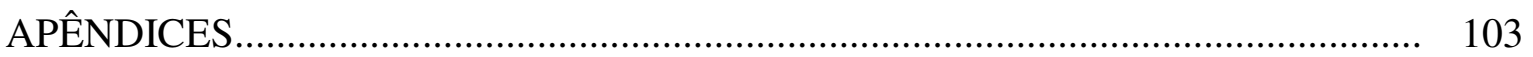




\section{RESUMO}

\section{Formação de estruturas androgenéticas por cultura de anteras de trigo em função de doses de nitrogênio e boro aplicadas às plantas doadoras}

O trigo é um alimento básico da humanidade cuja demanda cresce proporcionalmente ao aumento populacional. Existe carência de pesquisas sobre o efeito da nutrição da planta doadora na resposta androgenética. Este trabalho teve por objetivo avaliar a influência de cinco concentrações de nitrogênio e de boro $(25 \%, 50 \%, 100 \%, 150 \%$ e $200 \%)$ a partir da solução de Sarruge modificada, no cultivo de plantas de trigo doadoras de anteras visando à obtenção de estruturas embriogênicas androgenéticas. Para tanto, foram avaliados os componentes do rendimento (número de colmos, diâmetro e comprimento do colmo principal; comprimento, largura e área da folha bandeira; teor de clorofila da folha bandeira, distância entre a folha bandeira e o último nó e comprimento da espiga); o acúmulo de graus dias e duração do ciclo da semeadura até a coleta das espigas para a cultura de anteras; a formação de estruturas embriogênicas androgenéticas e o desenvolvimento dos micrósporos (tétrade, mononucleado central, mononucleado periférico, binucleado e pólen P). Constatou-se que as concentrações de nitrogênio afetaram significativamente os componentes do rendimento, a formação de estruturas embriogênicas androgenéticas e o desenvolvimento dos micrósporos. A duração do ciclo das plantas cultivadas na concentração de $25 \%$ de nitrogênio foi menor que nas demais doses, apresentando diferença de até 3,3 dias quando comparada às plantas submetidas a doses mais elevadas. Houve aumento linear na produção de estruturas embriogênicas androgenéticas em função das doses crescentes de nitrogênio utilizadas no cultivo das plantas doadoras das anteras. As doses de nitrogênio interferiram também no estádio de desenvolvimento dos micrósporos, para todas as variáveis estudadas. Essa influência no desenvolvimento dos micrósporos foi efetiva enquanto a folha bandeira menos um encontrava-se no primeiro terço de deslocamento em relação à distância total entre a folha bandeira e o último nó do colmo. As concentrações de boro utilizadas nas soluções de cultivo das plantas de trigo doadoras de anteras não influenciaram nos componentes do rendimento, na formação de estruturas embriogênicas, na duração do ciclo da planta e na maioria das variáveis estudadas com relação ao desenvolvimento dos micrósporos. O desenvolvimento dos micrósporos na espiga seguiu o padrão normal descrito para a espécie, independentemente dos nutrientes estudados. Concluiuse que as concentrações de nitrogênio influenciaram positivamente nos componentes do rendimento (exceto no comprimento da espiga), na formação de estruturas embriogênicas e na distância entre a folha bandeira e o último nó do colmo (marcador morfológico da coleta das espigas para cultura de anteras), enquanto que as concentrações de boro utilizadas no cultivo das plantas doadoras de anteras não apresentaram esse efeito.

Palavras-chave: componentes do rendimento; nutrição de plantas; haploide; androgênese; Triticum aestivum $\mathrm{L}$. 


\section{ABSTRACT \\ Formation of androgenetic structures by cultivation of wheat anthers in the role of nitrogen doses and boron applied to donor plants}

Wheat is the staple food of humanity whose demand grows in proportion to the population growth. There is lack of research about the effect of the nutrition of the donor plant in the androgenetic response. This work aim for evaluate the influence of five concentrations of nitrogen and boron $(25 \%, 50 \%, 100 \%, 150 \%$ and 200\%) from the solution of Sarruge modified, in the cultivation of wheat plants donors of anthers aiming the obtainment of androgenetics embryogenic structures. Both for, were evaluated the yield components (number stalks, diameter and length of the main stem; length, width and area of flag leaf; chlorophyll content of flag leaf, distance between flag leaf and the last node and ear length); the accumulation of degree-days and cycle duration of sowing until collection of ears to the anther's culture; the formation of androgenetics embryogenic structures and the development of microporous (determination of the number of cells in stages: tetrad, central mononucleate, peripheral mononucleate and binucleated and occurrence of pollen $\mathrm{P}$ ). It was found that the concentrations of nitrogen significantly affected the yield components, the formation of androgenetics embryogenic structures and the development of microspores. The duration of the cycle of the cultivated plants in the concentration of $25 \%$ of nitrogen was lower than in other doses, presenting difference of up to 3.3 days when compared to plants subjected to higher doses. There was a linear increase in the production of androgenetics embryogenic structures in function of increasing doses of nitrogen used in cultivation of donor plants of the anthers. The doses of nitrogen interfered also at the stage of development of microspores, for all variables studied. This influence on the development of microspores was effective while the flag leaf less one was in the first third of displacement in relation to the total distance between the flag leaf and the last node of the culm. The concentrations of boron used in solutions of cultivation of wheat donors plants of anthers did not affect the income components, in the formation of embryogenic structures, on the duration of the cycle of the plant and in the majority of the variables studied in relation to the development of the microspores. The development of microspores in spike followed the normal pattern described for the species, regardless of the nutrients studied. It was concluded that the concentrations of nitrogen positively influenced in yield components (except the length of the ear), the formation of embryogenic structures on and the distance between the flag leaf and the last node of the culm (morphological marker of collection of ears to anther culture), while the concentrations of boron used for the cultivation of plants donated anthers did not have this effect.

Keywords: Yield components; Plant nutrition; Haploid; Androgeneses; Triticum aestivum L. 


\section{LISTA DE FIGURAS}

Figura 1 - Esquema da morfologia da planta e das partes constituintes da espiga de trigo. Adaptado de Scheeren et al. (1984)......

Figura 2 - Esquema da diferença na segregação para dois genes recessivos e independentes em uma população $\mathrm{F}_{2} \times$ uma população duplo-haploide (DH). Adaptado de Pauls (1996)

Figura 3 - Esquema da inversão da rota gametofítica por esporofítica no desenvolvimento de embriões haploides de Brassica napus. Adaptado de Cordewener et al. (1996)

Figura 4 - Câmara de crescimento das plantas de trigo utilizadas como doadoras das anteras para o experimento (a). Distribuição dos vasos contendo as plantas de trigo da cultivar Genaro dentro da câmara (b)

Figura 5 - $\quad$ Plantas de trigo da cultivar Genaro produzidas em solução de Sarruge (1975) com cinco concentrações de nitrogênio. Os números 1 a 5 indicam as doses $25 \%, 50 \%, 100 \%, 150 \%$ e $200 \%$ de nitrogênio, respectivamente.

Figura 6 - Componentes do rendimento em plantas de trigo da cultivar Genaro produzidas em solução de Sarruge (1975), com cinco concentrações de nitrogênio expressos em: número de colmos por planta (a); diâmetro do colmo principal (b) e comprimento do colmo principal (c)

Figura 7 - Componentes do rendimento em plantas de trigo da cultivar Genaro produzidas em solução de Sarruge (1975), com cinco concentrações de nitrogênio expressos em: comprimento da folha bandeira do colmo principal (a); largura da folha bandeira do colmo principal (b) e área da folha bandeira do colmo principal (c) 
Figura 8 - Componentes do rendimento em plantas de trigo da cultivar Genaro produzida em solução de Sarruge (1975), com cinco concentrações de nitrogênio expressos em: massa fresca da parte aérea e massa seca da parte aérea (a); teor de clorofila da folha bandeira do colmo principal (b) e distância entre a folha bandeira e o último nó do colmo principal (c)

Figura 9 - Micrósporos oriundos de plantas de trigo da cultivar Genaro em diferentes estádios de desenvolvimento e pólen "P" visualizados em 400x de aumento. Tétrade (a); Mononucleado central (b); Mononucleado periférico (c); Binucleado (inicial) (d) e Pólen "P” (e) .

Figura 10 - Número de estruturas embriogênicas formadas pelas anteras cultivadas em quatro meios de cultura, em função das cinco concentrações de nitrogênio presentes na solução de Sarruge (1975) utilizadas no cultivo das plantas doadoras de anteras.

Figura 11 - Plântula haploide de trigo da cultivar Genaro produzida por organogênese direta a partir de anteras plaqueadas no meio de indução (a). Estruturas embriogênicas androgenéticas (calo) formadas a partir dos micrósporos de anteras cultivadas no meio de indução (b). Início da diferenciação das estruturas embriogênicas androgenéticas em plântulas (c). Plântulas haploides regeneradas in vitro (d). Aclimatização das plântulas haploides (e). Plantas aclimatizadas em câmara de cultivo (f). Análise citogenética das plantas regeneradas mostrando número haploide de cromossomos $(n=3 x=$ 21) (g). Análise citogenética de uma planta de trigo mostrando número normal de cromossomos $(2 \mathrm{n}=6 \mathrm{x}=42)$ aumentados 400x $(\mathrm{h})$

Figura 12 - Componentes do rendimento em plantas de trigo da cultivar Genaro produzidas em solução de Sarruge (1975), com cinco concentrações de boro, expressos em: número de colmos por planta (a); diâmetro do colmo principal (b) e comprimento do colmo principal (c). 
Figura 13 - Componentes do rendimento em plantas de trigo da cultivar Genaro produzidas em solução de Sarruge (1975), com cinco concentrações de boro, expressas em: comprimento da folha bandeira do colmo principal (a); largura da folha bandeira do colmo principal (b) e área da folha bandeira do colmo principal (c)

Figura 14 - Componentes do rendimento em plantas de trigo da cultivar Genaro produzidas em solução de Sarruge (1975), com cinco concentrações de boro, expressos em: massa fresca da parte aérea e massa seca da parte aérea (a); teor de clorofila da folha bandeira do colmo principal (b) e distância entre a folha bandeira e o último nó do colmo principal (c).

Figura 15 - Número médio de estruturas embriogênicas formadas a partir da cultura de anteras em quatro meios de cultura, em função das cinco concentrações de boro presentes na solução de Sarruge (1975) utilizadas na produção das plantas de trigo da cultivar Genaro doadoras de anteras 


\section{LISTA DE TABELAS}

Tabela 1 - Valores de pH e condutividade elétrica das soluções nutritivas utilizadas nos experimentos para o cultivo das plantas de trigo da cultivar Genaro doadoras de anteras.

Tabela 2 - Concentração de nitrogênio total na parte aérea das plantas de trigo da cultivar Genaro cultivadas em solução nutritiva descrita por Sarruge (1975), com cinco concentrações de nitrogênio, no momento do isolamento das espigas para cultura de anteras.

Tabela 3 - Número e massa de grãos, massa seca da palha e massa seca da parte aérea total de plantas de trigo da cultivar Genaro cultivadas em solução de Sarruge (1975), com cinco concentrações de nitrogênio, colhidas após a maturação fisiológica...

Tabela 4 - Número médio de graus-dias (GD) acumulados nos estádios fenológicos: emergência, espigueta terminal e ponto de coleta; média do total de graus-dias acumulados no período e média em dias, para atingir o ponto de coleta das espigas para a cultura de anteras em plantas de trigo da cultivar Genaro, cultivadas em cinco concentrações de nitrogênio a partir da solução de Sarruge $.1975)$.

Tabela 5 - Número médio de micrósporos por estádio de desenvolvimento e índice de polens "P" em plantas de trigo da cultivar Genaro, cultivadas em cinco concentrações de nitrogênio a partir da solução de Sarruge (1975), até o ponto de coleta das espigas para a cultura de anteras.

Tabela 6 - Número médio de micrósporos em diferentes estádios de desenvolvimento em três regiões da espiga de plantas de trigo cultivar Genaro, cultivadas em cinco concentrações de nitrogênio na solução de Sarruge (1975), no ponto de coleta para a cultura de anteras. 
Tabela 7 - Número médio de anteras plaqueadas oriundas das plantas de trigo, da cultivar Genaro, cultivadas em cinco concentrações de nitrogênio a partir da solução de Sarruge (1975)

Tabela 8 - Número médio de estruturas embriogênicas androgenéticas formadas nos meios de cultura utilizados para o cultivo das anteras oriundas das plantas de trigo, da cultivar Genaro, produzidas em cinco concentrações de nitrogênio a partir da solução de Sarruge (1975)

Tabela 9 - Concentração de boro total na parte aérea das plantas de trigo, da cultivar Genaro, cultivadas em solução nutritiva descrita por Sarruge (1975), com cinco doses de boro, no momento do isolamento das espigas para cultura de anteras.

Tabela 10 - Número e massa de grãos, massa seca da palha e massa seca da parte aérea total de plantas de trigo da cultivar Genaro cultivadas em solução de Sarruge (1975), com cinco concentrações de boro colhidas após a maturação

Tabela 11 - Número médio de graus-dias (GD) acumulados nos estádios fenológicos: emergência, espigueta terminal e ponto de coleta; média do total de graus-dias acumulados no período e média em dias, para atingir o ponto de coleta das espigas para a cultura de anteras de trigo da cultivar Genaro cultivadas em cinco concentrações de boro na solução de Sarruge. (1975).....

Tabela 12 - Número médio de micrósporos nos diferentes estádios de desenvolvimento e índice de polens "P" em plantas de trigo da cultivar Genaro, cultivadas em cinco concentrações de boro em relação a solução de Sarruge (1975), até o ponto de coleta das espigas para a cultura de anteras

Tabela 13 - Número médio de micrósporos em diferentes estádios de desenvolvimento em três regiões da espiga de plantas de trigo cultivar Genaro, cultivadas em cinco concentrações de boro na solução de Sarruge (1975), no ponto de coleta para a cultura de anteras 
Tabela 14 - Número médio de anteras plaqueadas oriundas das plantas de trigo, da cultivar Genaro, cultivadas em cinco concentrações de boro a partir da solução de

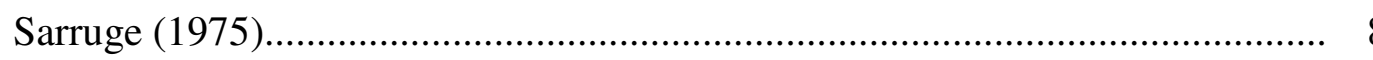

Tabela 15 - Número médio de estruturas embriogênicas androgenéticas formadas nos meios de cultura utilizados para o cultivo das anteras oriundas das plantas de trigo, da cultivar Genaro, produzidas em cinco concentrações de nitrogênio a partir da solução de Sarruge (1975)...... 


\section{INTRODUÇÃO}

O trigo é um alimento básico da humanidade, principalmente da civilização ocidental. A demanda de seus subprodutos cresce proporcionalmente ao aumento populacional e, dessa forma, este cereal representa uma importante commodity em nível mundial.

No Brasil, o trigo é cultivado desde 1534, mas só ganhou destaque comercial após a Segunda Guerra Mundial devido ao alto custo no mercado internacional. A partir daí, houve incentivo à pesquisa e ao desenvolvimento de novas variedades com a criação de estações experimentais as quais, se valeram de genótipos trazidos pelos imigrantes italianos que se adaptaram às condições ambientais especialmente, da região Sul do país dando origem aos programas de melhoramento genético atuais. Graças às pesquisas nas diferentes áreas do conhecimento, a produção desse cereal passou dos $600 \mathrm{~kg} \mathrm{ha}^{-1}$ na década de 70, para mais de $3164 \mathrm{~kg} \mathrm{ha}^{-1}$, em 2013 (INSTITUTO BRASILEIRO DE GEOGRAFIA E ESTATÍSTICA IBGE, 2014).

A obtenção de plantas haploides por meio da cultura de anteras e/ou micrósporos não tem atingido o sucesso necessário para garantir a regeneração de grande número de plantas verdes e assim, ser amplamente utilizada nos programas de melhoramento genético de trigo no Brasil.

Os estudos da influência da nutrição mineral em plantas de lavoura, geralmente, consideram a ação dos nutrientes sobre os componentes do rendimento e seu efeito na produtividade de grãos. Contudo, com relação à influência da nutrição em processos fisiológicos e/ou bioquímicos ou mais especificamente, naqueles envolvidos na resposta androgenética, existe grande carência de pesquisas.

Nesse sentido, este trabalho teve por objetivo avaliar a influência de cinco concentrações de nitrogênio e cinco concentrações de boro no cultivo de plantas de trigo doadora de anteras, visando relacionar a influência da nutrição da planta doadora com a capacidade de produção de estruturas embriogênicas androgenéticas para posterior obtenção de plantas haploides e duplo-haploides. 


\section{REVISÃO BIBLIOGRÁFICA}

2.1 Caracterização botânica e morfo-fisiológica do trigo

O trigo pertence à família Poaceae, Tribo: Triticeae D.; Subtribo: Triticinae; Gênero: Triticum; Espécie: Triticum aestivum L.. A espécie T. aestivum L. é um alohexaplóide (2n=6x = 42) fruto de uma hibridação natural entre Triticum turgidum (T. durum $2 \mathrm{n}=4 \mathrm{x}=28$ ) e uma gramínea selvagem chamada Aegilops squarrosa $(2 \mathrm{n}=2 \mathrm{x}=14)(\mathrm{LAW}$; DEAN; COUPLAND, 1993; BASU et al., 2011).

A planta de trigo é constituída por um colmo principal e por perfilhos, cujo número pode variar de acordo com o genótipo, disponibilidade de nutrientes do solo e densidade de semeadura. O sistema radicular é constituído por três tipos de raízes: as seminais, as da coroa e as adventícias. O desenvolvimento das folhas começa com a emissão do coleóptilo e em média apresenta de cinco a seis folhas que correspondem ao número de entrenós. Cada folha é constituída pela bainha, lâmina, lígula e um par de aurículas na base da lâmina. A distribuição das folhas é alternada. O colmo é oco, cilíndrico e constituído de quatro a sete entrenós cuja distância entre eles pode variar. Após o perfilhamento, ocorre rápida elongação dos entrenós, bem como acúmulo de reservas que serão translocadas para as espigas durante o período de enchimento de grão (FORNASIERI FILHO, 2008; SCHEEREN et al., 2011).

O sistema reprodutor é constituído por uma espiga composta, dística, formada por espiguetas que se distribuem de forma alternada e opostas ao longo da ráquis. Cada espigueta pode apresentar de três a nove flores dispostas de forma alternada na ráquila. Na base da espigueta encontram-se duas brácteas chamadas glumas que protegem a flor, a qual, é constituída por uma lema e uma pálea, por fim, três anteras circundam o estigma plumoso e bipartido. O fruto do trigo é do tipo cariopse, que mede de seis a sete milímetros, seco e indeiscente, podendo apresentar forma, comprimento e largura diferenciada. Cada flor pode originar um grão (Figura 1) (FORNASIERI FILHO, 2008; SCHEEREN et al., 2011) 

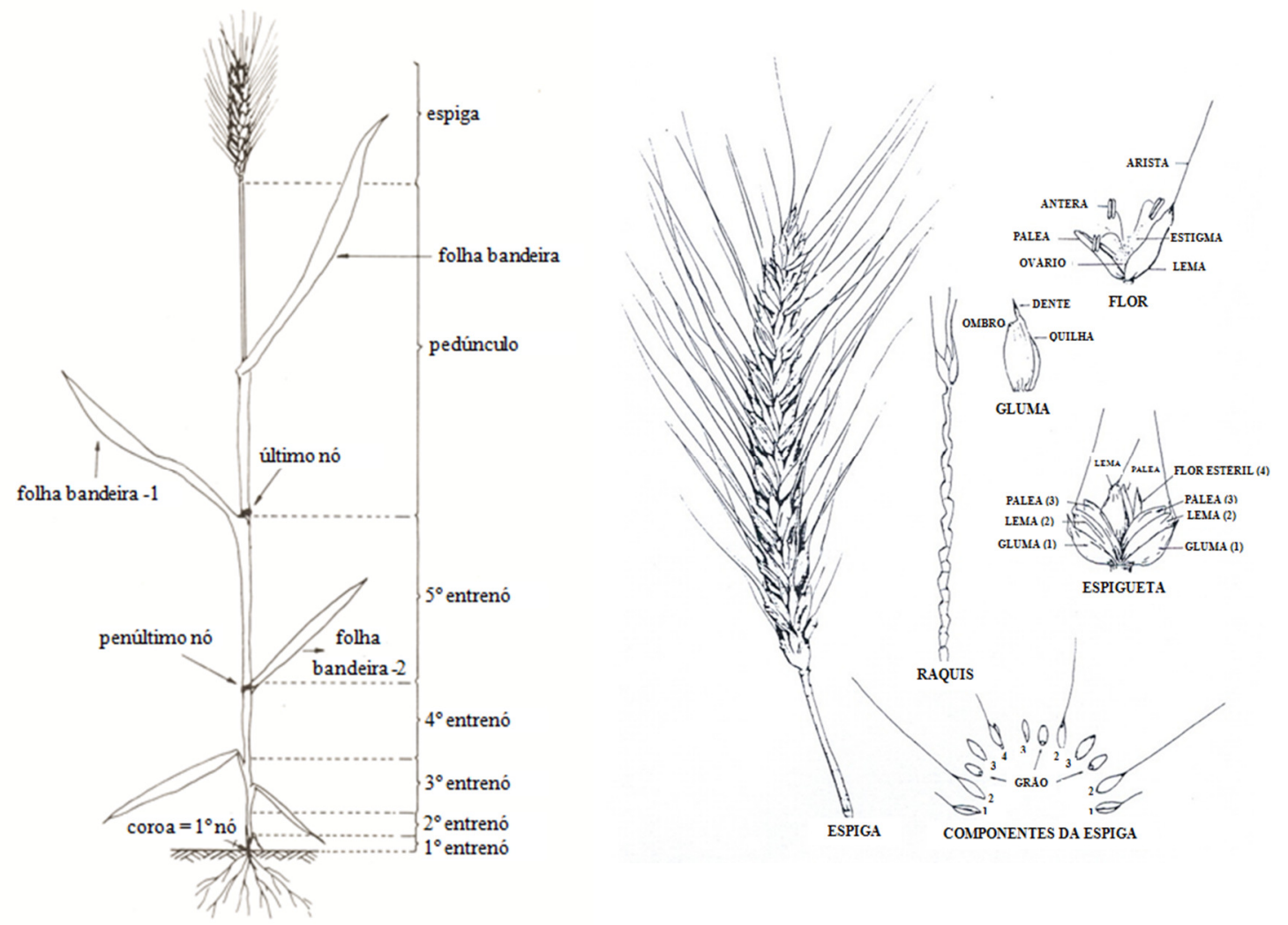

Figura 1 - Esquema da morfologia da planta e das partes constituintes da espiga de trigo. Adaptado de Scheeren (1984)

2.2 A cultura do trigo no Brasil - História e perspectivas

No Brasil, o trigo foi introduzido na Capitania de São Vicente em 1534, e a partir daí, distribuído por todo o país, acompanhando a colonização. No Rio Grande do Sul, a cultura foi introduzida em 1737, com a chegada dos colonizadores açorianos, tornando-se a primeira cultura em importância na época, seguida pelo milho, feijão, mandioca e arroz. A expansão da cultura foi tão grande, que no ano de 1795 iniciaram as exportações do cereal e consequentemente, o estado ganhou o título de "celeiro do Brasil" (OSÓRIO, 1982; LAGOS, 1983; SOUZA, 1997; ARIAS, 1999)

Em 1811, o surgimento e a propagação da ferrugem (Puccinia triticina) provocou grandes perdas nas lavouras de trigo de tal modo que em 1823, não existiam mais cultivos no Sul do Brasil. A cultura do trigo só voltou a ter incentivo na metade final do século XIX com a chegada dos colonizadores italianos, os quais trouxeram novas variedades que foram mantidas em pequenas áreas de cultivo para subsistência (COPSTEIN, 1999). Dentre essas variedades 
trazidas da Itália, algumas se adaptaram às condições edafoclimáticas da região Sul e serviram como base para a consolidação da triticultura brasileira. Contudo, a triticultura recebeu incentivos significativos a partir do período entre as duas grandes guerras mundiais que, devido ao elevado valor do trigo no mercado internacional, forçou o governo brasileiro a investir em medidas que possibilitassem o aumento da produção nacional. As primeiras linhagens que deram origem ao melhoramento genético no Brasil foram selecionadas na estação experimental Alfredo Chaves, atual unidade da Fundação Estadual de Pesquisa Agropecuária (FEPAGRO Serra, em Veranópolis - RS), e na unidade Experimental de Ponta Grossa (PR) (SCHEEREN et al., 2011).

De acordo com Scheeren et al. (2011), atualmente, a pesquisa em melhoramento de trigo no Brasil é executada por órgãos governamentais, instituições paraestatais e por empresas privadas distribuídas por todas as regiões tritícolas do país.

A produção mundial de trigo na safra 2012/13 foi de 659 milhões de toneladas e o consumo estimado foi de 683,9 milhões de toneladas. No ano de 2013, o Brasil semeou 2.209.745 ha de trigo produzindo 5.711.803 toneladas de grão o que perfaz produtividade média de $2.585 \mathrm{~kg} . \mathrm{ha}^{-1}$. Dessa forma, a demanda brasileira de trigo é estimada em 11 milhões de toneladas por ano é suplementada com trigo importado, principalmente da Argentina. (IBGE, 2014).

Entre os principais fatores limitantes e desafios da triticultura no Brasil, destacam-se as condições climáticas desfavoráveis (geadas, estiagens, alta umidade relativa, etc.), a carência de genótipos tolerantes ao alumínio tóxico do solo, a instabilidade das safras em rendimentos qualidade tecnológica, a não preservação da identidade do produto, a forte dependência de políticas governamentais para os produtores que sofrem na competição com o produto importado de melhor qualidade industrial e menor custo por conta de acordos comerciais (FORNASIERI FILHO, 2008; DE MORI; IGNAZAK, 2011).

2.3 Nutrição mineral de plantas - Considerações gerais

A nutrição mineral de plantas estuda a forma de aquisição e a função de cada um dos nutrientes dentro da planta (EPSTEIN; BLOOM, 2006). Os vegetais obtêm os nutrientes do solo, na forma de íons inorgânicos os quais são fundamentais para a formação, partição e a utilização dos fotoassimilados e consequentemente, responsáveis pelo desenvolvimento de toda 
a planta, uma vez que representam sua fonte de energia (CAKMAK; ENGELS, 1999; REID, 1999; TAIZ; ZEIGER, 2010).

Devido à origem aquática da vida na Terra, a substância com maior abundância nas plantas é a água. Nos tecidos frescos dos vegetais, essa substância pode representar cerca de 80 a 90\%. Como consequência, átomos de hidrogênio $(H)$ e oxigênio $(\mathrm{O})$ combinados excedem em número todos os outros elementos químicos dos tecidos vegetais. Além desses, o terceiro elemento mais abundante é o carbono (C), uma vez que este se encontra constituindo todas as moléculas orgânicas de tal modo que, os três elementos juntos ( $\mathrm{CHO}$ ) somam não menos que 90\% da massa seca de uma planta (DANIEL-VEDELE; CHAILLOU, 2005; EPSTEIN; BLOOM, 2006). Porém, os demais elementos são fundamentais para o controle e a realização de processos metabólicos responsáveis pelo crescimento e desenvolvimento das plantas.

O mecanismo de absorção dos nutrientes no sistema radicular da planta não exerce seletividade sob o que está sendo absorvido. Porém, nem todos os nutrientes presentes no xilema das plantas serão, de fato, utilizados por elas em seu metabolismo. Nesse sentido, um elemento ou nutriente ser considerado essencial para a planta, ele tem que se enquadrar em um ou mais dos três critérios a seguir: a) a planta não consegue completar seu ciclo de vida na ausência desse nutriente; b) a função do nutriente não pode ser substituída por outro; c) o nutriente está diretamente envolvido no metabolismo da planta (KIRKBY, 2012).

Segundo Taiz e Zeiger (2010), os nutrientes são geralmente classificados em macronutrientes e micronutrientes conforme a concentração nos tecidos das plantas. São considerados macronutrientes, aqueles constituintes de compostos orgânicos como proteínas, ácidos nucleicos ou que atuam na regulação osmótica normalmente, requerido em grandes concentrações pelas plantas $\left(\mathrm{g}^{\cdot} \mathrm{kg}^{-1}\right)$. Pertencem a esse grupo: nitrogênio, potássio, cálcio, magnésio, fósforo e. enxofre. Os micronutrientes são aqueles que predominantemente, fazem parte da constituição molecular das enzimas e desempenham seu papel mesmo que em concentrações muito baixas na planta $\left(\mathrm{mg}^{\cdot} \mathrm{kg}^{-1}\right)$. Pertencem a esse grupo: o cloro, ferro, boro, manganês, zinco, cobre, níquel e molibdênio (KIRKBY, 2012).

Uma nova classificação para os nutrientes tem sido sugerida e, de acordo com ela, os elementos devem ser agrupados em quatro grupos: 1) Nutrientes que constituem compostos orgânicos - nitrogênio e enxofre, elementos assimilados por reações bioquímicas de oxidação e redução; 2) Nutrientes importantes nas reações de acúmulo de energia e manutenção da integridade estrutural - a esse grupo pertence o fósforo, boro e o silício os quais formam grupos covalentemente ligados a uma molécula orgânica; 3) Nutrientes que permanecem na forma iônica - grupo de íons livres dissolvidos em água ou eletrostaticamente ligados a substâncias 
como os ácidos pécticos da parede celular. São importantes, pois atuam como co-fator enzimático e reguladores do potencial osmótico das células. Esse grupo é representado pelo: potássio, cálcio, magnésio, cloro, manganês e sódio e; 4) Nutrientes que estão envolvidos em reações redox - desempenham importante papel nas reações envolvendo a transferência de elétrons. Pertence a esse grupo: ferro, zinco, cobre, níquel e molibdênio (TAIZ; ZEIGER, 2010; KIRKBY, 2012).

Quando a concentração de um nutriente encontra-se abaixo do necessário para o crescimento ótimo da planta, esta é dita deficiente neste nutriente. A falta de um nutriente pode promover alterações de amplas proporções no metabolismo e no crescimento da planta. Como, e geralmente, uma reação metabólica é parte de uma cadeia de processos, outros processos, além daqueles imediatamente controlados pelo nutriente, são afetados de modo que o padrão de toda a rota metabólica fica comprometido caso a condição de deficiência seja muito severa ou se prolongue ao longo dos estádios fenológicos da planta (KIRKBY, 2012). Na prática, os distúrbios causados no metabolismo pela deficiência de um nutriente podem reduzir a velocidade de crescimento e diminuir a capacidade produtiva da planta, muitas vezes, antes mesmo que os sintomas de carência se tornem visíveis.

A capacidade das plantas assimilarem carbono nos órgãos fonte e translocar os fotoassimilados para os pontos de demanda (drenos), a qual determina sua capacidade de crescimento, desenvolvimento e produtividade, é altamente afetada por fatores como a disponibilidade de água, condições de luminosidade e disponibilidade de nutrientes. A síntese de sacarose pela Sacarose-Fosfato-Sintase (SPS) é altamente afetada pelos nutrientes minerais, sendo que geralmente, apresenta correlação inversa de sua atividade com o nível de nutrientes acumulados nas folhas e correlação direta com a síntese de sacarose. Além disso, a nutrição mineral tem efeito sobre a partição dos carboidratos, afetando o transporte dos mesmos via floema e/ou diminuição da taxa de crescimento dos órgãos fonte (CAKMAK; ENGELS, 1999).

A absorção dos nutrientes é um processo extremamente importante para o crescimento da planta. Normalmente, as plantas desenvolvem mecanismos para aumentar a eficiência na exploração do ambiente onde elas se encontram suprindo assim, suas necessidades. Dentre esses mecanismos, pode-se ressaltar a codificação de proteínas carreadoras presentes na membrana plasmática as quais servem como porta de entrada para os elementos nas células. Nesse sentido, Reid (1999) ressaltou que aproximadamente $12 \%$ do genoma das plantas são utilizados para codificar tais proteínas, sendo conhecidos cerca de 1000 carreadores diferentes. Muitas vezes, para o transporte de um único nutriente é utilizada mais que uma proteína carreadora ou para sua absorção é necessário um sistema múltiplo de carreadores. 
É importante ressaltar que o transporte de nutrientes nos tecidos das plantas é fortemente influenciado pela concentração do nutriente no tecido. Alguns transportadores podem ir e vir, e outros podem simplesmente aumentar ou diminuir sua atividade de acordo com a demanda. Essa inconstância pode provocar estresse na planta uma vez que, o solo é um meio altamente instável sob o ponto de vista da disponibilidade de nutrientes na rizosfera (REID, 1999). Por outro lado, a taxa de transporte de íons através da membrana plasmática da planta é determinada pelo número e atividade das proteínas transportadoras presentes na membrana. O número de transportadores por sua vez, é determinado pela taxa de transcrição dos genes que codificam essas proteínas e estes decaem pela taxa de RNAm e pela meia vida dessas proteínas. Contudo, o alto nível de expressão de alguns genes codificadores de proteínas carreadoras, indica que as plantas podem rapidamente aumentar o número de transportadores na membrana plasmática quando necessário (SMITH, 1999).

\subsubsection{O nitrogênio}

Segundo Taiz e Zeiger (2010), o nitrogênio é o elemento mineral requisitado em maior quantidade pelas plantas. Ele constitui muitos componentes celulares incluindo aminoácidos, proteínas e ácidos nucleicos (DANIEL-VEDELE; CHAILLOU, 2005). A carência de nitrogênio impede rapidamente o crescimento das plantas. Em quadros severos de carência, as folhas ficam completamente amareladas (clorose), principalmente, as localizadas na região basal da planta. Pode ocorrer ainda, o endurecimento dos tecidos devido ao acúmulo excessivo de carboidratos os quais não são utilizados na síntese de aminoácidos e outros compostos nitrogenados. Em algumas espécies de plantas, esses carboidratos podem ser utilizados para a síntese de antocianinas e, consequentemente, os tecidos das folhas, pecíolos e caules podem apresentar coloração purpúrea.

Conforme Malavolta (2006), 98\% do nitrogênio encontra-se compondo a matéria orgânica do solo e apenas $2 \%$ está na forma mineral. $\mathrm{O}$ nitrato $\left(\mathrm{NO}_{3}{ }^{-}\right)$e o amônio $\left(\mathrm{NH}_{4}{ }^{+}\right)$ representam as maiores fontes de nitrogênio inorgânico absorvido pelas raízes das plantas superiores.

\subsubsection{Assimilação de nitrato $\left(\mathrm{NO}_{3}{ }^{-}\right)$}

Nos vegetais a primeira etapa de assimilação do nitrato $\left(\mathrm{NO}_{3}{ }^{-}\right)$é marcada pela redução a nitrito $\left(\mathrm{NO}_{2}{ }^{-}\right)$o que ocorre da seguinte forma: $\mathrm{NO}_{3}{ }^{-}+\mathrm{NADH}(\mathrm{P}) \mathrm{H}+\mathrm{H}^{+}+2 \mathrm{e}^{-} \rightarrow \mathrm{NO}_{2}{ }^{-}+$ 
$\mathrm{NAD}(\mathrm{P})+\mathrm{H}_{2} \mathrm{O}$. Normalmente, o composto nicotinamida adenina dinucleotidio reduzido (NADH) é utilizado como doador de elétrons (órgãos verdes), porém, nos tecidos não verdes (raízes, por exemplo) pode ser utilizado tanto o NADH como o composto nicotinamida adenina dinucleotidio fosfato reduzido NADPH (EPSTEIN; BLOOM, 2006).

Conforme Daniel-Vedele e Chaillou (2005), a redução do nitrato a nitrito requer a ação de duas enzimas, a redutase do nitrato (NR) e a redutase do nitrito (NiR). A expressão dos genes que codificam a enzima redutase do nitrato, bem como a atividade enzimática é aumentada em função do nível de $\mathrm{NO}_{3}{ }^{-}$, da intensidade luminosa ou da concentração de carboidratos no órgão (EPSTEIN; BLOOM, 2006). Consequentemente, ocorre a síntese de novas moléculas da enzima e a produção de uma fosfatase que desfosforila várias moléculas de serina na enzima nitrato redutase ativando-a. Por outro lado, fatores como a escuridão e a concentração de íons $\mathrm{Mg}^{2+}$, estimulam a enzima quinase que fosforila as mesmas moléculas de serina da redutase do nitrato tornando-a novamente inativa. Essa regulação da redutase do nitrato por desfosforilação e fosforilação promove rápido controle ao processo quando comparado à síntese e à degradação da enzima cujo processo pode levar minutos e horas, respectivamente, e é considerada a chave da rota de assimilação do nitrato (BUCHANAN, GRUISSEM; JONES, 2000).

O nitrito gerado no citoplasma é rapidamente transportado para os cloroplastos nas folhas e para os plastídios nas raízes, uma vez que é potencialmente tóxico para as células. Nessas organelas a enzima redutase do nitrito reduz esse composto a $\mathrm{NH}_{4}^{+}$. Embora essa enzima apresente diferentes formas dependendo do local em que esteja atuando (folha ou raiz), em ambos os casos há a transferência de elétrons da ferridoxina para o $\mathrm{NO}_{2}{ }^{-}$, conforme a reação a seguir: $\mathrm{NO}_{2}^{-}+6 \mathrm{FD}_{\text {red }}+8 \mathrm{H}^{+}+6 \mathrm{e}^{-} \rightarrow \mathrm{NH}_{4}{ }^{+}+6 \mathrm{FD}_{\mathrm{ox}}+2 \mathrm{H}_{2} \mathrm{O}$. A ferridoxina reduzida nos cloroplastos é oriunda do transporte fotossintético de elétrons, enquanto que nos tecidos não verdes, é fruto do NADPH gerado pela via oxidativa da pentose do fosfato (EPSTEIN; BLOOM, 2006; HAWKESFORD et al. 2012).

A enzima redutase do nitrito contêm dois grupos prostéticos: um ferro-enxofre $\left(\mathrm{Fe}_{4} \mathrm{~S}_{4}\right)$ e um grupo heme especializado. $\mathrm{O}$ par $\mathrm{Fe}_{4} \mathrm{~S}_{4}$-heme se liga ao $\mathrm{NO}_{2}{ }^{-}$e o reduz a $\mathrm{NH}_{4}{ }^{+}$. A redutase do nitrito é codificada no núcleo e sintetizada como um precursor ligado a um peptídeo com terminal $\mathrm{N}$ que é direcionado para os plastídios. A síntese dessa enzima é induzida pelo acúmulo de $\mathrm{NO}_{3}{ }^{-}$, pela intensidade de luz, concentração de nitrato e fitohormônios. Sua inibição é feita pelo acúmulo dos aminoácidos asparagina e glutamina (HAWKESFORD et al. 2012).

A concentração e disponibilização do nitrato para as plantas determinam se sua incorporação vai ocorrer na raiz ou na parte aérea. Plantas submetidas a doses baixas de nitrato apresentam alta taxa de conversão de nitrato para nitrito na raiz. Quando a disponibilidade de 
nitrato é alta na raiz este é transportado para a parte aérea (MARSCHNER, 1995). Além disso, a assimilação de $\mathrm{NO}_{3}{ }^{-}$pela parte aérea depende da fotorespiração. A assimilação de nitrogênio inorgânico é controlada por genes que são altamente influenciados por fatores ambientais como a luz e fatores inerentes do metabolismo da própria planta como a concentração de carboidratos e aminoácidos (BUCHANAN, GRUISSEM; JONES, 2000).

\subsubsection{Assimilação do amônio $\left(\mathrm{NH}_{4}{ }^{+}\right)$}

Conforme Marschner (1995), o amônio pode ser muito tóxico para células vegetais, contudo, as plantas desenvolveram mecanismos capazes de assimilar esse composto na forma iônica incorporando-o a esqueletos carbônicos originando os aminoácidos, amidas e compostos relacionados ou então o decompondo a nitrato e nitrito. A principal porta de entrada do amônio iônico ocorre nas raízes, onde ele é incorporado aos aminoácidos e/ou amidas com a liberação simultânea de prótons, os quais atravessam a membrana plasmática.

Segundo Buchanan, Gruissem e Jones (2000), durante o processo de assimilação do amônio as plantas utilizam três aminoácidos transportadores: o glutamato, aspartato e a asparagina. Esses compostos são utilizados na transferência do nitrogênio dos órgãos fonte para os tecidos drenos ou de reserva para, posteriormente, utilizá-lo no crescimento, defesa ou reprodução. O nitrogênio assimilado na forma de glutamato e glutamina é o mais comumente encontrado nos tecidos da planta e é utilizado na biossíntese de aminoácidos, ácidos nucleicos e outros compostos nitrogenados. Os principais compostos utilizados nesse processo são o aspartato e a asparagina. O aspartato é um aminoácido altamente reativo, que é utilizado metabolicamente como doador de nitrogênio em inúmeros processos de reações de aminotransferase. A asparagina, por sua vez, é um composto inerte que atua na estocagem de nitrogênio.

A absorção do amônio pelas plantas pode ocorrer por diferentes vias. De acordo com Taiz e Zeiger (2010), primeiramente, a enzima Glutamina Sintetase (GS) associa o amônio com o glutamato formando uma molécula de glutamina. Essa reação requer a hidrólise de uma molécula de adenosina trifosfato (ATP) e a utilização de um cátion divalente como co-fator, podendo ser utilizado $\mathrm{Mg}^{2+}, \mathrm{Mn}^{2+}$ ou $\mathrm{Co}^{2+}$. $\mathrm{O}$ aumento do nível de glutamina nos plastídios estimula a ativação da enzima Glutamato Sintase, também conhecida como Glutamina 2Oxoglutarato Aminotransferase (GOGAT), a qual transfere o grupo amida da glutamina para o 2-oxoglutarato oriundo do ciclo de Krebs, produzindo assim, duas moléculas de glutamato (DANIEL-VEDELE; CHAILLOU, 2005). Outra forma de absorção pode ocorrer quando a 
enzima Glutamato Dehidrogenase (GDH) catalisa uma reação reversível na qual sintetiza ou desamina o glutamato. A partir da sua assimilação dentro da glutamina ou glutamato, o nitrogênio vai sendo incorporado dentro de aminoácidos através de reações de transaminação, mediadas por enzimas chamadas aminotransferases. Essas enzimas encontram-se no citoplasma, peroxissomos, mitocôndrias, glioxissomos e cloroplastos, nos quais desempenham importante papel na fixação do carbono oriundo do dióxido de carbono durante a biossíntese de aminoácidos.

Existe uma conexão entre a asparagina e a glutamina na regulação do metabolismo do nitrogênio e do carbono. Isso ocorre porque a asparagina é um aminoácido que, além de compor as proteínas, desempenha papel chave no transporte e armazenamento de nitrogênio já que apresenta alta estabilidade e a melhor relação C:N dentre os aminoácidos (4:2) (DANIELVEDELE; CHAILLOU, 2005).

Altos níveis de luminosidade e de carboidratos na célula inibem a expressão dos genes codificadores da enzima Asparagina Sintase (AS) e estimulam a expressão dos genes codificadores das enzimas GS e GOGAT, o que favorece a assimilação do nitrogênio complexado aos aminoácidos glutamina e glutamato, os quais são ricos em carbono e participam da síntese de novos compostos na planta. Sob condições contrárias, baixa luminosidade e concentração de carboidratos, ocorre a inibição da GS e GOGAT e o estímulo a AS, o que favorece assimilação do nitrogênio fixado a asparagina o qual é rico em nitrogênio e suficientemente estável para transportá-lo até os órgãos de reserva (TAIZ; ZEIGER, 2010).

\subsubsection{O boro}

Segundo Marschner (1995), a absorção do boro está relacionada ao pH, à sua concentração na solução do solo e à presença de água no solo. A distribuição na planta é controlada pelo fluxo da transpiração através da mobilidade do floema. Broadley et al. (2012) ressaltaram que seu transporte nas plantas que utilizam a sacarose como carboidrato primário é primeiramente afetado pela taxa de transpiração. Nas plantas que transportam os compostos carbônicos através de polióis, o boro trafega livremente pelo floema como um elemento móvel.

O papel do boro na nutrição das plantas ainda não está completamente elucidado. Contudo, o boro é importante no transporte de açúcares, síntese de parede celular, lignificação, na estrutura da parede celular, no metabolismo dos carboidratos, na síntese dos ácidos nucléicos, na respiração, no metabolismo do ácido indolacético (AIA), no metabolismo de fenóis, na integridade das membranas e na regulação do ciclo celular, sugere que o boro se 
encontra envolvido em número muito grande de rotas metabólicas (SHIVANNA, 2003; RAVEN; EVERT; EICHHORN, 2010; TAIZ; ZEIGER, 2010, BROADLEY et al., 2012). O boro também atua na inibição de compostos fenólicos livres que são tóxicos para as células, bem como em inúmeros processos bioquímicos que ocorrem na membrana plasmática, inclusive no funcionamento da ATPase (SHIVANNA, 2003).

O ácido bórico tem grande capacidade de se complexar com grupos químicos dióis (cis-diol) e polióis. Compostos polihidrixil com um adjacente cis-diol são utilizados, por exemplo, para a síntese de compostos complexos como inúmeros açúcares (manitol, manan e ácido polimanurônico), que constituem a hemicelulose da parede celular e compostos $O$ difenólicos como o ácido caféico e ácido hidroxiferrulico, precursores da síntese de lignina. Complexos mais estáveis são formados com cis-diols sobre um anel furanóide, nominalmente ribose e apiose, originando um composto comum na parede celular (MARSCHNER, 1995).

O boro atua no aumento da capacidade de produção de pólen pelas anteras, bem como na sua viabilidade. Além disso, desempenha importante papel durante a elongação do tubo polínico. Em plantas com deficiência de boro, ocorre aumento na síntese de calose que induz aumento na síntese das fitoalexinas no estigma e estiletes de forma semelhante a resposta de defesa contra um agente fitopatogênico. A carência de boro provoca sintomas por toda a planta, podendo afetar a elongação das raízes, o metabolismo dos ácidos nucléicos, a síntese da parede celular, o metabolismo dos fenóis, o metabolismo da auxina (AIA) e a diferenciação dos tecidos, o funcionamento das membranas, a germinação do pólen e o crescimento do tubo polínico e o metabolismo de carboidratos e proteínas. Um sintoma característico de sua deficiência é a necrose negra das folhas jovens e gemas terminais. Nas células das raízes de plantas com deficiência, há a diminuição da concentração, bem como da taxa de síntese de DNA. As taxas de RNA também caem rapidamente, em função do aumento da taxa de RNAse nos tecidos (BROADLEY et al., 2012).

A sensibilidade à falta de boro na cultura do trigo é muito influenciada pelo genótipo. Em experimento visando quantificar a influência do elemento na indução de esterilidade nessa cultura, Rekasem e Jamjod (1997) constataram que genótipos com sensibilidade alta e moderada, tratados com doses muito baixas de boro foram completamente estéreis enquanto que os genótipos tolerantes produziram grãos normalmente.

Os sintomas típicos de toxicidade provocada pelo boro são a clorose nas margens das folhas maduras e a necrose. Em trigo a dose de boro pode ser aumentada em até 20 vezes sem efeito negativo na germinação das sementes ou no crescimento das plântulas (BROADLEY et al., 2012). 
2.4 Indução do florescimento: considerações gerais

A transição da fase juvenil para a adulta, bem como a indução do florescimento depende de inúmeros fatores ambientais e endógenos da planta e representam a chave para o sucesso reprodutivo (MATSOUKAS, MASSIAH; THOMAS, 2012)

Segundo Rodrigues et al. (2011), os marcadores para a caracterização das fases fenológicas do trigo são: a emergência das plântulas, a iniciação floral (duplo anel), a iniciação da espigueta terminal e a antese. O critério mais adequado para a caracterização dos estádios fenológicos do trigo é a análise do ápice de crescimento ou meristema apical. A iniciação floral é marcada pelo estádio de duplo-anel a partir do qual termina a emissão de folhas e inicia o processo de formação das espiguetas da espiga o qual acaba com a emissão da última espigueta da espiga, o que caracteriza o estádio de espigueta terminal. Os dois principais fatores que afetam a transição entre o estádio vegetativo e o reprodutivo no trigo são a temperatura baixa (vernalização) e o fotoperíodo.

A vernalização é o processo pelo qual o florescimento é promovido através da exposição da planta a baixas temperaturas e pode acelerar o início do florescimento nas plantas (STREET; ÖPIK, 1984; TAIZ; ZEIGER, 2012). Conforme Rodrigues et al. (2011), existe relação linear entre a temperatura média e a taxa de crescimento das plantas de trigo para cada fase fenológica, o que permite quantificar a duração de cada uma delas em tempo térmico ou graus-dias acumulados (GD). O efeito da vernalização é mais efetivo em temperaturas de $0^{\circ} \mathrm{C}$ a $7^{\circ} \mathrm{C}$ (STREET; ÖPIK, 1984; RODRIGUES et al., 2011) e sua atuação é mais sensível nos meristemas das gemas apicais (FLOSS, 2004). A manipulação da duração de cada fase fenológica do trigo pode contribuir para aumentar a eficiência na utilização dos nutrientes, e consequentemente, contribuir para o aumento da produtividade da cultura (RODRIGUES et al., 2011).

O fotoperíodo, por sua vez, determina quantas horas de luz a planta necessita para passar do estádio vegetativo para o reprodutivo. Nesse sentido, os trigos podem ser classificados em primaveris (altamente sensíveis ao fotoperíodo), invernais (alta sensibilidade a vernalização) e mediterrâneos (forte sensibilidade ao fotoperíodo e ligeira sensibilidade a vernalização) (RODRIGUES et al., 2011). A interação entre vernalização e fotoperíodo pode representar importante ferramenta na busca de maior eficiência de produção na cultura de trigo. Contudo, Floss (2004) ressaltou que ao contrário do fotoperiodismo, a vernalização por si só, não é capaz de induzir a floração. 
2.5 Biologia da formação do pólen

Os grãos de pólen se desenvolvem nas anteras as quais, quando jovens, são formadas por uma massa homogênea de células meristemáticas envolvidas por uma epiderme (SHIVANNA, 2003). O desenvolvimento das anteras envolve grande histodiferenciação que resulta em muitas células e tecidos altamente especializados. Ao longo do desenvolvimento do pólen, algumas dessas células continuam se diferenciando enquanto outras degeneram. A diferenciação e a degeneração ocorrem em uma ordem temporal e espacial ao longo da antera e culminam com a produção e dispersão dos grãos de pólen. A microsporogênese e a microgametogênese são fundamentais para a propagação das plantas e envolvem processos que incluem divisão e diferenciação celular, comunicação célula a célula e morte celular programada (MA, 2005).

\subsubsection{Diferenciação dos tecidos nas anteras}

Segundo Shivanna (2003), a antera madura representa uma estrutura biteca ou tetraesporangiada na qual células e tecidos são formados originários das três camadas germinativas presentes nos meristemas florais $\left(\mathrm{L}_{1}, \mathrm{~L}_{2}\right.$ e $\left.\mathrm{L}_{3}\right)$. $\mathrm{A} \mathrm{L}_{1}$ dá origem à epiderme, $\mathrm{L}_{2} \mathrm{a}$ hipoderme (arquespório) e a $\mathrm{L}_{3}$ ao tecido conectivo e feixe vascular central (ZHANG; LUO E ZHU, 2011). A epiderme $\left(L_{1}\right)$ e o tecido conectivo $\left(L_{3}\right)$ não sofrem modificações significativas a partir de sua origem, no interior da antera. Porém na camada $\mathrm{L}_{2}$ surge o tapete como linhas no interior dos locos das anteras e um pequeno grupo de células separando os sacos polínicos um para cada lado da antera (septo interesporangial). Em seguida, a antera assume uma forma de quatro lóbos e as células arquesporiais passam a constituir quatro grupos (microesporângios). Os microesporângios são células diferenciadas por apresentarem citoplasma denso e grandes núcleos. As células arquesporiais se dividem e formam duas camadas uma mais externa parietal primária e uma mais interna de esporângios primários. Os esporângios primários realizam divisão mitótica e dão origem às células mãe dos micrósporos. Essa camada de células mãe e o tapete são locais de intensa atividade metabólicas durante a meiose (SHIVANNA, 2003; MA, 2005; RAVEN; EVERT; EICHHORN, 2010; NAKAMURA; LONGHI-WAGNER; SCATENA, 2010; ZHANG; LUO; ZHU, 2011). 


\subsubsection{A microsporogênese}

A microsporogênese compreende a formação dos micrósporos ou grãos de polens unicelulares. Conforme Iwanami, Sasakuma e Yamada (1988), os micrósporos são formados pela divisão meiótica das células mãe de micrósporos dentro dos microsporângios, ou sacos polínicos das anteras. A meiose é o evento mais importante que ocorre durante a microsporogênese. Após o início da meiose (fase S), as divisões celulares das células arquesporiais tornam-se sincronizadas. Conforme Shivanna (2003), a cultura de anteras antes do início da meiose não tem apresentado sucesso, nem mesmo quando botões florais são cultivados in vitro. Contudo, uma vez iniciada a meiose, esta continua mesmo em anteras isoladas e cultivadas in vitro. Porém, pode haver sérias anormalidades cromossômicas dependendo do estágio em que a antera foi isolada (leptóteno, por exemplo). Em células isoladas a partir do zigóteno o ciclo meiótico ocorre normalmente. (BATYGINA, 2002; RAVEN; EVERT; EICHHORN, 2010).

A maior parte das moléculas de DNA é sintetizada nas células mãe de micrósporos na fase $\mathrm{S}$ da meiose, porém, uma pequena porção ainda é sintetizada durante o zigóteno e o paquíteno. Isso é importante para coordenar o progresso da meiose. A inibição da prófase resulta na retenção de fragmentos de cromossomos durante o zigóteno. A síntese de DNA durante o zigóteno é normalmente semiconservativa e representa um atraso na porção de replicação dos cromossomos que não a fizeram na fase S. A síntese de DNA durante o paquíteno (enquanto ocorre a formação dos quiasmas) tem característica de reparo, principalmente, dos eventos associados ao crossing over. Quanto à síntese de RNA e proteínas, esta é intensa durante a fase $S$, decaindo na prófase de forma que a partir da metáfase I não há síntese de RNA e proteínas até o final da meiose (SHIVANNA, 2003).

Após a meiose, ocorre a reorganização do citoplasma das células dos meiócitos, uma vez que durante a divisão celular o número de organelas cai rapidamente. A partir da metáfase I, os plastídios e as mitocôndrias realizam a desdiferenciação e rediferenciação e permanecem normais até o final da tétrade. As anteras jovens apresentam conexões plasmodesmais entre as células da parede, do tapete e do tecido esporogênico, bem como nos tecidos adjacentes. $\mathrm{O}$ início da meiose é caracterizado pelo início da deposição de calose na parede das células mãe de micrósporos. Inicialmente, a parede de calose é incompleta, e essas falhas formam uma grande massa de canais citoplasmáticos que proporcionam a troca de substâncias e organelas entre as células mãe de micrósporos (OWEN; MAKAROFF, 1995). Essa rede atinge seu ápice no período compreendido entre o zigóteno e o paquíteno. Todas as células mãe de micrósporos 
de um esporângio formam entidade citoplasmática simples chamada sincício. O sincício atua como um eficiente sistema de distribuição de nutrientes entre as células mãe de micrósporos e o esporângio. A sincronia entre os meiócitos é progressivamente interrompida até que esse sistema de tubos seja desligado. A deposição de calose na parede celular dos meiócitos (micrósporos) é essencial para o desenvolvimento do pólen, e a ocorrência de falhas nessa deposição conduz a esterilidade (SCOTT, 1994; SHIVANNA, 2003; MA, 2005).

O isolamento dos micrósporos é importante para o seu desenvolvimento por no mínimo dois motivos: 1) para a transição do micrósporo da fase esporofítica para a gametofítica; 2) para a expressão do genoma gametofítico sem a interferência de outros esporos ou mesmo do tecido gametofítico adjacente e por fim, a parede de calose representa uma fonte de nutrientes para o desenvolvimento dos micrósporos, principalmente no que diz respeito aos carboidratos solúveis (SHIVANNA, 2003).

\subsubsection{A microgametogênese}

Segundo Raven, Evert e Eichhorn (2010), a microgametogênese compreende o desenvolvimento do microgametófito no interior do grão de pólen até o estádio final de desenvolvimento. Inicialmente, a parede de calose é degradada e os micrósporos são liberados dentro do lóculo da antera. Após a tétrade, os micrósporos apresentam um grande núcleo central e organelas citoplasmáticas normais e iniciam a fase de desenvolvimento na qual se expandem rapidamente, podendo atingir 2,5 vezes o seu volume inicial. Essa expansão se dá graças à flexibilidade da exina e é sustentada pelo fornecimento de nutrientes oriundos do metabolismo da calose.

A divisão do micrósporo é o maior evento morfogenético após a formação da tétrade, um grande vacúolo se desenvolve no centro do micrósporo acompanhado pela migração dos núcleos para a periferia. Após a migração do núcleo, os plastídios e mitocôndrias também migram para a região próxima do núcleo. Este, por sua vez, sofre divisão mitótica formando uma célula filha. Uma parede celular surge entre a membrana dos dois núcleos e se fixa à intina da margem do micrósporo, promovendo uma divisão assimétrica. Como resultado surge uma grande célula vegetativa com citoplasma contendo muitos plastídios e mitocôndrias e uma pequena célula generativa cujo citoplasma contém poucas ou até mesmo nenhuma organela (SHIVANNA, 2003; ZHANG; LUO; ZHU, 2011). Na sequência, o vacúolo é reabsorvido e a célula generativa se desprende da intina e é novamente rodeada por uma parede de calose. $\mathrm{Na}$ célula vegetativa, inicia a deposição do amido e substâncias de reserva como lipídios. Isso, 
geralmente, ocorre de modo simultâneo a regressão do tapete. Embora tanto a célula vegetativa como a germinativa sejam fruto de uma divisão mitótica, as duas são funcional e estruturalmente muito diferentes inclusive quanto à constituição da cromatina de seus núcleos. A célula germinativa se divide mitoticamente e formam as duas células espermáticas. $\mathrm{Na}$ maioria das espécies vegetais $(70 \%)$, os grãos de pólen são liberados nessa fase, porém, na família Poaceae, a qual pertence o trigo, os grãos de pólen maduros apresentam três células, uma vez que há uma divisão da célula espermática antes do grão de pólen ser liberado da antera (McCORMICK, 1993; SHIVANNA, 2003; MA, 2005).

2.6 O melhoramento genético clássico - considerações gerais

De acordo com Scheeren et al. (2011), os principais métodos empregados no melhoramento genético do trigo no Brasil são: Genealógico ou Pedigree, Massal, Single Seed Descent (SSD), retrocruzamento, Seleção recorrente e Seleção sistêmica. Desses, o método genealógico também chamado de Pedegree é o mais utilizado pelos melhoristas. Esse método permite melhor controle de seleção. Contudo, demanda maior quantidade de recursos, tanto de área experimental quanto de mão de obra. Além disso, é um método muito dependente da interação genótipo $\times$ ambiente.

Pelo método genealógico, para ser obtida uma nova linhagem demora em torno de sete a oito anos. Esse é o tempo necessário para que o material se torne homozigoto e não segregue mais suas características ao longo das gerações. Após esse período, as novas linhagens passam para as avaliações de campo, ensaios em rede, avaliação do valor de cultivo e uso (VCU) e, finalmente, é lançada como uma nova cultivar, podendo esse tempo ultrapassar 10 anos.

2.7 Plantas haploides e duplo-haploides

Conforme Shivanna (2003), plantas haploides são esporófitos que apresentam o número gametofítico de cromossomos. As plantas haploides podem ser obtidas por duas vias distintas: gimnogênese e androgênese. 


\subsubsection{A gimnogênese}

Esta técnica compreende a obtenção de plantas haploides a partir da oosfera, ou seja, contendo apenas o conjunto cromossômico materno. Diversos métodos podem ser utilizados para a obtenção de plantas por esse método como, por exemplo, a cultura de ovários e o método de eliminação somática, método esse muito comum nos programas que adotam a gimnogênese como forma de obtenção de plantas haploides e duplohaploides (SHIVANNA, 2003). O método consiste no cruzamento entre duas espécies no qual se espera que os cromossomos oriundos do progenitor masculino sejam totalmente eliminados após as primeiras divisões somáticas do zigoto. Como consequência, o zigoto apresentará apenas as características genéticas maternas e se for resgatado e cultivado in vitro poderá regenerar uma planta haploide. O mecanismo de eliminação cromossômica nos cruzamentos interespecíficos ou intergenéricos não está bem conhecido. Porém, sabe-se que em alguns casos a espécie utilizada como genitor feminino apresenta genes específicos para a eliminação em seu genoma, ou então o embrião (híbrido) sintetiza endonucleases que fragmentam e consequentemente, eliminam o genoma de um dos genitores. Dentre as várias espécies utilizadas para a produção de plantas duplo-haploides em trigo, destacam-se o Hordeum bulbosum L. e o milho (Zea mays L.). A principal vantagem da gimnogênese é a facilidade de obtenção de plantas quando comparada à androgênese. A produção de linhas de trigo duplo-haploides pelo método trigo $\times$ milho foi amplamente utilizado no Centro Nacional de Trigo nas décadas de 1980 e 1990 (MORAES-FERNANDES et al., 1999).

A grande desvantagem da gimnogênese é o número de plantas obtidas, que se resume a uma por flor, enquanto que na cultura de anteras e/ou micrósporos pode ser muito elevado devido ao grande número de micrósporos por flor (2000 a 3000 grãos/antera), no caso do trigo (PICARD et al., 1990).

\subsubsection{A androgênese e a haplodiploidização no melhoramento de plantas}

Conforme Powell (1990), a produção de plantas através da androgênese pode ser realizada por duas vias: a cultura de anteras e/ou a cultura de micrósporos isolados, os quais podem originar plantas por embriogênese ou organogênese. Desde a descoberta da cultura de anteras por Guha e Maheshwari em 1964, essa técnica já foi empregada para a obtenção de calos embriogênicos e plantas em mais de 247 espécies, 88 gêneros e 34 famílias, com destaque para cereais, como trigo, cevada (Hordeum vulgare L.), triticale (Triticum $\times$ Secale), arroz 
(Oryza sativa L.) e milho, entre outros (MANTELL; MATTHEWS; McKEE, 1994; PETERS, BOBROWSKI; ROSINHA, 1999).

Conforme Peters, Bobrowski e Rosinha (1999), o sucesso da produção de haploides depende de fatores como a fisiologia da planta doadora, estádio de desenvolvimento dos micrósporos, pré-tratamento utilizado, composição do meio de cultura, condições da cultura, genótipo da planta doadora, entre outros.

De acordo com Moraes-Fernandes et al. (1999), a haplodiploidização representa uma poderosa estratégia tecnológica para o melhoramento de culturas autógamas por representar a segregação gamética após a meiose de indivíduos híbridos $\left(\mathrm{F}_{1}\right)$. Assim, facilitando o desenvolvimento de linhagens puras em cereais, promovendo grande economia de tempo, aumento de variabilidade genética, melhoria da resposta de seleção, além de ser relevante para testar e identificar cruzamentos promissores. Nesse sentido, Brammer et al. (2011) ressaltaram que a produção de plantas haploides de trigo quer seja pelo emprego de cruzamentos interespecíficos com milho, ou pela cultura de anteras e/ou micrósporos isolados tornou-se um método largamente utilizado na produção de linhagens homozigotas nos programas de melhoramento genético.

A capacidade androgenética refere-se à potencialidade do grão de pólen em dar origem a um embrióide ou calo que resultará em uma planta. Vários fatores podem determinar o desvio da rota gametofítica para a esporofítica, entre eles os genéticos, fisiológicos e os ambientais. Nesse sentido, Grando e Moraes-Fernandes (1987), ressaltaram que os polens-P (pré-mitótico) em trigo apresentam totipotência e, portanto, são responsáveis pela produção de plantas haploides.

Conforme Roca et al. (1991), a eficiência de seleção em programas de melhoramento aumenta quando este se vale da cultura de anteras. Isso se deve ao fato de que as células de pólen dos híbridos $F_{1}$ apresentam a constituição genética dos pais e a recombinação esperada pelas proporções mendelianas (Figura 2). 


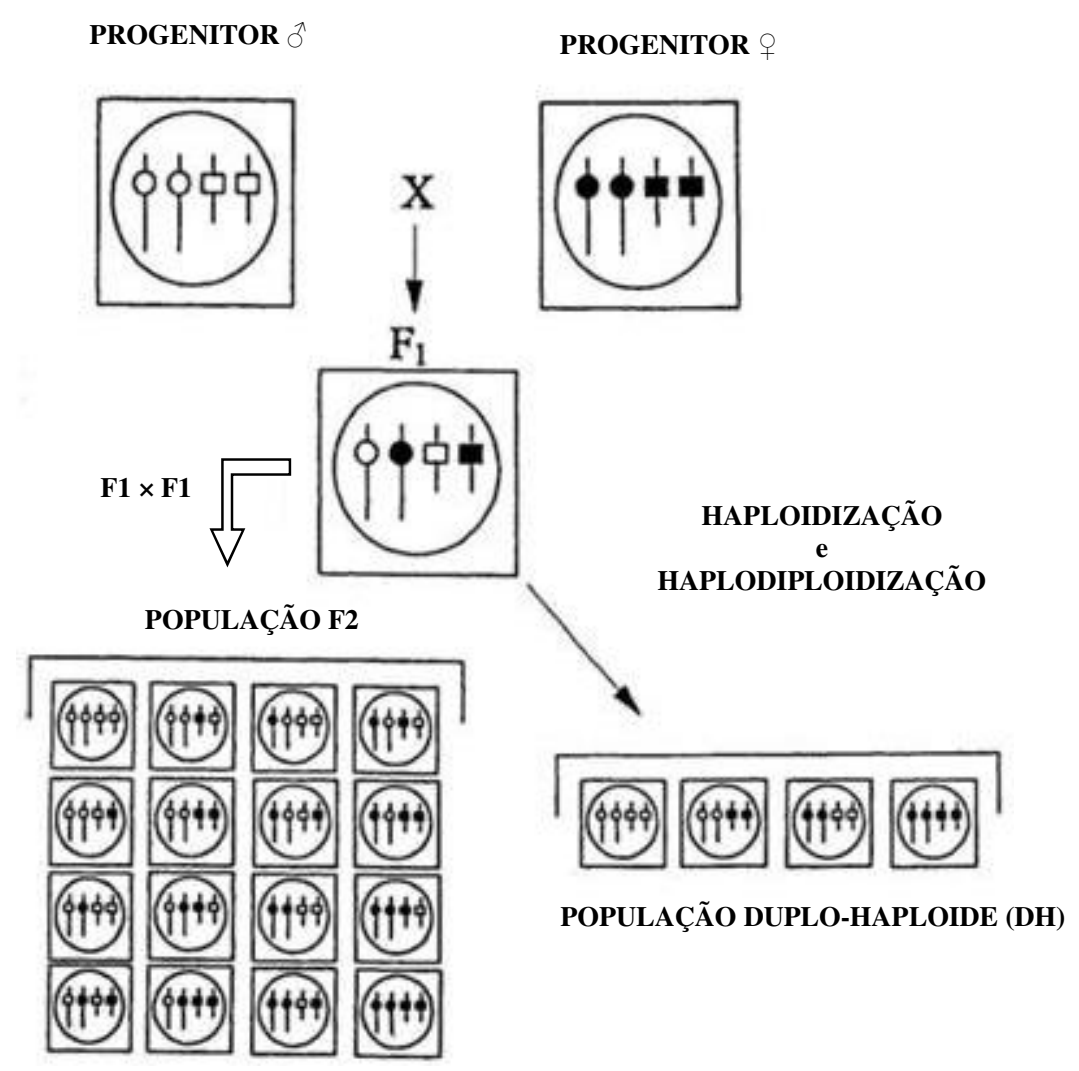

Figura 2 - Esquema da diferença na segregação para dois genes recessivos e independentes em uma população $\mathrm{F}_{2} \times$ uma população duplo-haploide (DH). Adaptado de Pauls (1996)

Dentre as vantagens da utilização de plantas haploides em programas de melhoramento, destaca-se a economia de tempo para a obtenção da homozigose que passa a ser de apenas uma geração, ao passo que no melhoramento tradicional só pode ser obtida após sete a nove gerações de autopolinização. Isso acarreta em significativa redução no período de tempo necessário para o lançamento de um novo cultivar. No caso do trigo, a homozigose essencial para a seleção pode ser obtida dentro de oito a nove meses. Em período máximo de 18 meses já é possível a obtenção das 200 gramas de sementes necessárias para iniciar a experimentação de uma nova linhagem. Além disso, a obtenção da homozigose instantânea aumenta a eficiência de seleção de caracteres qualitativos e quantitativos, podendo ser utilizada a raiz quadrada do número de plantas do método convencional, aumentando ainda mais a eficiência de seleção nos programas de melhoramento. Para características recessivas sua probabilidade de seleção é duas vezes maior (BAJAJ, 1990; KHUSH; VIRMANI, 1996; MORAES-FERNANDES et al., 1999). 
A utilização da técnica de haplodiploidização nos programas de melhoramento tem-se mostrado altamente eficiente nas linhagens F3, reduzindo consideravelmente o tempo de lançamento de uma nova cultivar (BAENZIGER, 1996).

A resposta androgenética é uma característica altamente herdável e dessa forma, possível de seleção genética. Conforme Moraes-Fernandes et al. (1999), em trigo a dependência do genótipo é bastante significativa, sendo necessário o desenvolvimento de estratégias de melhoramento para a produção de plantas responsivas à androgênese, inclusive bancos de germoplasma.

De modo geral, a cultura de anteras ou micrósporos isolados, representa uma técnica muito útil para a introgressão de características desejáveis em programas de melhoramento genético de cereais (CAETANO; MORAES-FERNANDES, 1992).

Tem-se utilizado linhagens duplo-haploides para a realização de mapeamento genômico, principalmente pelo fato de que as plantas duplo-haploides apresentam maior segurança na relação entre as marcas detectadas pelos marcadores moleculares e a sua expressão fenotípica já que não apresentam a expressão intermediária dos heterozigotos. Nesse sentido, a utilização de plantas duplo-haploides, torna-se uma ferramenta interessante no mapeamento de QTL (Quantitative Trait Loci), que expressam a interação genótipo $\times$ ambiente (KHUSH; VIRMANI, 1997).

Conforme Baenziger (1996), o baixo número de cultivares lançado pelo método de haplodiploidização se deve ao pequeno número de laboratórios que desenvolvem esse tipo de plantas. As principais causas da não utilização da técnica são: a falta de mão de obra especializada nos programas de melhoramento, o custo do desenvolvimento de uma linhagem duplo-haploide, a dependência genotípica da resposta androgênica, o fato dos melhoristas temerem variações gametoclonais com efeito deletério e a resistência em empregarem uma nova metodologia que pode não resultar em sucesso.

\subsubsection{Cultivo de anteras e/ou micrósporos isolados}

A formação de gametas nas plantas representa o desenvolvimento de estruturas especializadas e tipos celulares que facilitam o movimento e a recombinação do material genético. O pólen é formado tipicamente por três células encaixadas dentro de uma parede altamente resistente. Essas células, após a maturação do grão de pólen, são diferenciadas e vão realizar o seu papel específico durante a fertilização da célula ovo. O processo de inversão da rota gametofítica para a esporofítica ocorre quando os micrósporos jovens encontram-se na fase 
mononucleado (MARASCHIN et al., 2005; PAULS et al., 2006). Conforme Reynolds (1997), várias espécies de plantas podem apresentar aptidão à inversão da rota gametofítica para a esporofítica podendo, sob condições favoráveis, originar um embrião com a metade da carga genética da planta mãe (haploide).

De acordo com Barnabás, Szak'acs e Bedö (2001), o estágio crítico para o desenvolvimento dos micrósporos encontra-se no momento do desvio da rota gametofítica para a esporofítica, mais precisamente, no estágio mononucleado ou unicelular. No final da mitose, os micrósporos podem originar uma divisão equitativa formando duas células morfologicamente idênticas capazes de continuar o processo de divisão originando embriões ou calos (Figura 3).

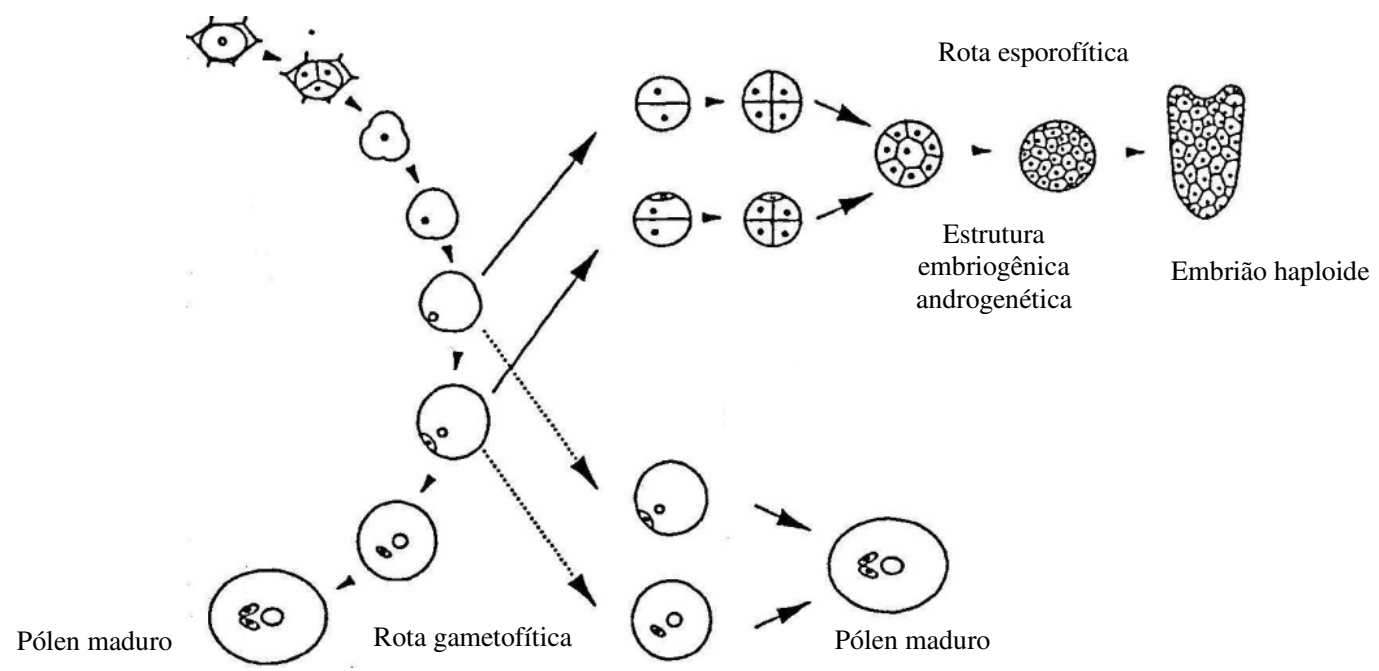

Figura 3 - Esquema da inversão da rota gametofítica por esporofítica no desenvolvimento de embriões haploides de Brassica napus. Adaptado de Cordewener et al. (1996)

Touraev, Pfosser e Heberle-Bors (2001) salientaram que uma grande vantagem de se utilizar a via androgênica para a produção de plantas duplo-haploides é o grande número de micrósporos produzidos, os quais, se convertidos em plantas, podem originar significativo número de linhagens homozigotas permitindo que todas as características dominantes ou recessivas possam ser avaliadas diretamente. Contudo, há baixa eficiência na produção de linhagens duplo-haploides por esse método, devido às dificuldades de regeneração de plantas verdes e a relevante ocorrência de plantas albinas (PATEL et al., 2004).

Conforme Maraschin et al. (2005), a exposição dos micrósporos a estresses durante o pré-tratamento, pode ativar ou desativar genes específicos capazes de determinar o sucesso no processo androgenético. Nesse sentido, Muñoz-Amatriaín et al. (2009) ressaltaram que o 
estresse ambiental tem um papel decisivo na embriogênese dos micrósporos, não somente pela necessidade de ativar a diferenciação mas também na ativação da embriogênese propriamente dita, porém, seus mecanismos moleculares ainda são pouco estudados.

É conhecido o efeito de fatores ambientais sobre a resposta à androgênese dos micrósporos. Assim, um dos principais fatores, é a condição nutricional da planta doadora das anteras e/os micrósporos. Entretanto, variáveis como: a densidade das plantas, qualidade e intensidade da luz, fotoperíodo e temperatura, também podem interferir na aptidão dos micrósporos em originar embriões (ZHENG, 2003).

Após a retirada das espigas das plantas doadoras, fatores como os pré-tratamentos realizados antes da extração dos micrósporos, o método de isolamento, a densidade de micrósporos, o balanço hormonal do meio de cultura e a fonte de carbono utilizada, o co-cultivo com ovários frescos não fecundados, bem como a temperatura de incubação, podem interferir significativamente na obtenção de plantas verdes e na taxa de albinismo (GUSTAFSON, 1995; HU et al., 1995; EKIZ; KONZAK, 1997; HU; INDRIATO; HEBERLE-BORS; TOURAEV, 1999; SMYKÁL, 2000; LABBANI; BUYSER; PICARD, 2007). Nesse sentido, ŚlusarkiewiczJarzina e Ponitka (2009) relataram que na cultura de anteras de linhagens híbridas de aveia (Avena sativa L.), houve influência significativa do estado físico do meio de cultura em alguns genótipos estudados.

\subsubsection{Biologia da indução da androgênese}

Ao longo do ciclo de vida, as plantas apresentam duas fases distintas: uma diploide ou esporofítica, e outra, haploide ou gametofítica. A primeira representa a maior parte da vida da planta, enquanto a segunda é representada pelo período em que a planta encontra-se na forma de gametas durante reprodução sexuada. Na fase gametofítica a planta apresenta dois tipos de gametófitos, os micrósporos ou gametófitos masculinos e o megásporo ou saco embrionário que representam os gametófitos femininos (que abrigam a oosfera). Durante a gametogênese masculina, as células passam por uma sequência de modificações definidas que culminam com a formação de uma célula altamente especializada contendo uma grande célula vegetativa e duas células espermáticas. O processo de formação dessa estrutura é rigorosamente controlado para que ocorram apenas duas divisões celulares. Porém, durante a cultura de anteras e/ou micrósporos, os gametófitos masculinos passam por uma via alternativa que conduz à formação de um embrião haploide sem necessidade de passar pela fecundação. Há muitas evidências que a inversão da rota é controlada por genes que interagem entre si e com o ambiente 
(DICKINSON, 1992). Segundo Zaki e Dickinson (1993), a inversão da rota gametofítica para a esporofítica ocorre em micrósporos que encontram-se em estágio de desenvolvimento próximo a primeira divisão mitótica e a formação de plantas haploides a partir dos micrósporos pode ocorrer por diferentes rotas podendo envolver a organogênese direta e/ou indireta (HU, 1997). Rota 01: durante a primeira divisão mitótica o micrósporo realiza citocinese assimétrica e a célula vegetativa dá origem a um embrião. Rota 2: o micrósporo sofrem uma divisão simétrica na primeira mitose e as células seguem em divisão originando um embrião. Rota 3: envolve a realização de uma divisão assimétrica e as células filhas se fundem e formam uma célula diploide que continua se dividindo e dá origem a um embrião Rota 4: a célula generativa realiza as divisões mitóticas e origina o embrião enquanto a célula vegetativa se degenera e

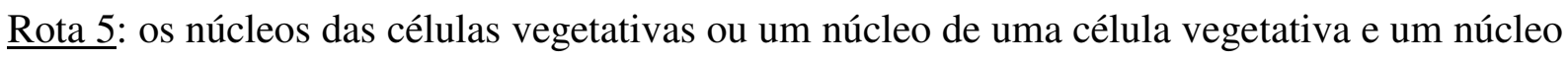
da célula generativa se unem e formam um embrião (ZAKI; DICKINSON, 1993; AIONESEI; TOURAEV; HEBERLE-BORS, 2005).

A indução de modificações no desenvolvimento é fruto da ativação de fatores específicos capazes de causar alterações no padrão de expressão gênica durante o prétratamento e parece estar associado à capacidade de resposta dos micrósporos ao estresse (CORDEWERNER et al., 1996).

2.8 Fatores que interferem na resposta androgenética do trigo

2.8.1 Temperatura da câmara de crescimento das plantas doadoras das anteras

A variação de dois graus durante o pré-tratamento na cultura de anteras é capaz de representar grande diferença na resposta androgenética de trigo (HUANG, 1990).

A temperatura afeta o desenvolvimento dos micrósporos podendo provocar redução na formação de estruturas embriogênicas tanto pelo aumento quanto pela diminuição da temperatura. Desta forma, a utilização de câmaras de cultivo e/ou casas de vegetação com alto rigor no controle de temperatura tem se mostrado indispensável na produção de plantas haploides androgenéticos de trigo. Os trabalhos realizados até o momento indicam que as variações entre baixas e altas temperaturas afetam mais significativamente a resposta androgenética do que sua ação em faixas isoladas (somente alta ou baixa temperatura) (HEBERLE-BORS; REINERT, 1979, HENRY; BUYSER, 1990; HUANG, 1990; PICARD et 
al., 1990; FERRIE; PALMER; KELLER, 1995; DEVAUX; PICKERING, 2005; DATTA, 2005; TENHOLA-ROININEN; ANHUANPÄÄ; IMMONEN, 2005).

2.8.2 Intensidade luminosa da câmara de crescimento das plantas doadoras

A influência do fotoperíodo e da intensidade luminosa, às quais as plantas doadoras são submetidas durante o crescimento, interferem na resposta à produção de estruturas embriogênicas de diversas espécies, incluindo trigo. Foi observada a interação temperatura $\times$ fotoperíodo sobre a regeneração de calos e plantas verdes oriundas da cultura de anteras e/ou micrósporos (HEBERLE-BORS; REINERT, 1979, HENRY; BUYSER, 1990; FERRIE; PALMER; KELLER,1995).

\subsubsection{Genótipo das plantas doadora de anteras e/ou micrósporos}

A resposta androgenética em trigo é uma característica altamente herdável. A influência do genótipo sobre a cultura de anteras e/ou micrósporos isolados já foi largamente estudada em todo o mundo. Para a maioria dos autores esse é o principal fator que afeta a produção de plantas haploides androgenéticas em trigo (HU, 1997; MORAES-FERNANDES, 1999). Tem-se observado que a influência genotípica pode ocorrer de duas formas, uma por genes relacionados à inversão da rota gametofítica para a esporofítica e a outra pela influência de genes relacionados com a capacidade de regeneração de plantas verdes a partir dos calos oriundos da cultura de anteras e/ou micrósporos isolados.

2.8.4 Nutrição da planta doadora de anteras e/ou micrósporos

Dentre os fatores fisiológicos que interferem na resposta androgenética, a nutrição da planta doadora é geralmente mencionada. A influência da adubação nitrogenada na resposta androgenética foi demonstrada por Heberle-Bors e Odenbach (1985) na cultura de anteras de fumo (Nicotiana tabaco) e de trigo. Em nível mundial, a influência da nutrição das plantas doadoras carece de mais informações e trabalhos capazes de quantificá-la (SMÝKAL, 2000). Nesse sentido, Ferrante, Savin e Slafer (2013), ressaltaram que existe grande carência de informações acerca da influência da adubação principalmente nitrogenada, no desenvolvimento floral durante o processo de elongação no trigo (FERRIE; PALMER; KELLER, 1995). 
$\mathrm{O}$ fornecimento de nitrogênio nas plantas doadoras das anteras altera a frequência de polens "P" (polens embriogênicos), os quais na natureza são estéreis, mas nas condições de cultura são hábeis na inversão da rota gametofítica para a esporofítica (HEBERLE-BORS; ODENBACH, 1985).

Segundo Tremblay e Colasanti (2006), o aumento na disponibilidade de nitrogênio aumenta a concentração de fotoassimilados na planta e consequentemente, a eficiência do processo de indução de formação de estruturas florais. Nesse sentido, Street e Öpik (1986) afirmaram que o número de flores é controlado pela disponibilidade de nutrientes na planta.

\subsubsection{Pré-tratamento de frio das anteras}

Ao longo da história da produção de plantas haploides, inúmeros pré-tratamentos nas espigas, anteras e/ou micrósporos têm demonstrado influência significativa tanto na indução de embrióides e/ou calos quanto na produção de plantas verdes (FERRIE; PALMER; KELLER, 1995). Dentre esses pré-tratamentos, a utilização de um choque de frio $\left(3-4^{\circ} \mathrm{C}\right)$ nas anteras de trigo recém plaqueadas durante cinco a sete dias tem demonstrado resultados significativos. Segundo Picard et al. (1990), isso se deve à sincronização do ciclo celular, bem como a indução da formação de maior números de polens "P" que seriam os mais responsivos à inversão da rota gametofítica para a esporofítica. Em cevada, o pré-tratamento aplicado nos micrósporos isolados interfere na taxa de regeneração de plantas albinas, plantas verdes bem como, na fertilidade das mesmas (HUANG, 1990; LABBANI et al., 2005; OLESZCZUK; ZIMNY, 2006).

2.8.6 Estádio de desenvolvimento dos micrósporos

O estádio de desenvolvimento dos micrósporos interfere diretamente na capacidade de inversão da rota gametofítica para a esporofítica e, consequentemente, na formação de calos embriogênicos e na regeneração de plantas haploides. A resposta androgenética é positiva quando as anteras e/ou os micrósporos são isolados no período que compreende o estádio mononucleado central até o binucleado (FERRIE; PALMER; KELLER, 1995, SHIVANNA, 2003). Contudo, o ponto ideal para o isolamento pode variar dependendo do tipo de explante utilizado (antera ou micrósporos isolados), devido à interferência dos tecidos da parede da antera. A coleta e o isolamento das anteras e/ou micrósporos na fase correta de desenvolvimento representa um dos pontos mais importantes no processo de produção de plantas haploides 
androgênicas, sendo necessário o treinamento da equipe responsável pelo projeto na identificação do ponto de coleta bem como, a análise citológica do desenvolvimento. Assim, tem-se observado, em nível mundial, a busca por um mecanismo prático (morfológico) para a identificação do ponto de coleta das espigas. Frequentemente, é utilizado o padrão morfológico que leva em consideração a distância percorrida pela folha bandeira menos um (FB-1) em relação à distância total entre a folha bandeira (FB) e o último nó do colmo (UN) (nó de inserção do pedúnculo da espiga) como indicador para a coleta das espigas. De acordo com esse padrão, quando a folha bandeira menos um percorre um terço da distância total entre a folha bandeira e o último nó, a maioria dos micrósporos encontra-se no estádio mononucleado (GRANDO; MORAES-FERNANDES, 1989).

\subsubsection{Meio de cultura}

O meio de cultura desempenha um papel crítico no processo de produção de plantas através da cultura de anteras e/ou micrósporos isolados. As principais modificações observadas dizem respeito ao tipo e à concentração da fonte de carbono, da fonte de nitrogênio e dos reguladores de crescimento utilizados. Para a androgênese em cereais, de modo geral, a fonte de carbono mais utilizada nos meios de cultura é a sacarose em dosagens elevadas ( 8 a 9 por cento do volume total do meio). A substituição da sacarose por outros carboidratos como frutose, maltose e glicose já foi estudada e apresentou diferenças significativas dependendo do genótipo utilizado no que diz respeito a indução de calos e regeneração de plantas verdes. Quanto à fonte de nitrogênio, a utilização de aminoácidos como a glutamina, tem apresentado resultados positivos. Os reguladores de crescimento por sua vez, podem influenciar na frequência de embriogênese e a ação deles está relacionada com o genótipo e as condições ambientais de cultura (FERRIE; PALMER; KELLER, 1995; HU, 1997). 


\section{MATERIAL E MÉTODOS}

3.1 Material vegetal utilizado

Em teste preliminar foram avaliadas diversas variedades de trigo quanto a habilidade em formar estruturas embriogênicas androgenéticas: Bobwhite, Fielder, Veery Sib, Sonora 64, Kenya 58, Genaro, BR43 e IAC 24. Entre tais variedades, a única que se destacou em produção de estruturas embriogênicas foi a cultivar Genaro e, por isso, ela foi selecionada para a realização do experimento, cujas sementes foram obtidas junto ao Centro Nacional de Pesquisa do Trigo da Empresa Brasileira de Pesquisa Agropecuária (Embrapa Trigo). Essa cultivar representa uma linhagem cujo cruzamento original (KVZ/BUHO//KAL/BB) foi realizado Centro Internacional de Melhoramento Milho e Trigo (CIMMYT), no México e, posteriormente, distribuída a vários centros de pesquisa do mundo. No Brasil, na Embrapa Trigo, essa linhagem deu origem a duas cultivares lançadas comercialmente, a BR 26 - San Gotardo indicada para cultivo no Paraná e a BR 31 Biriti indicada para cultivo na região de cerrado do Mato Grosso do Sul.

Foram semeadas 20 sementes em cada vaso (com capacidade volumétrica para oito litros) por experimento e após a germinação foram deixadas 15 plantas vigorosas e uniformes por vaso. O substrato utilizado foi perlita expandida e os vasos foram mantidos em câmara de crescimento de plantas no Instituto Federal de Educação, Ciência e Tecnologia do Rio Grande

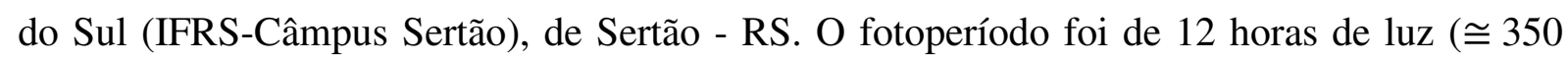

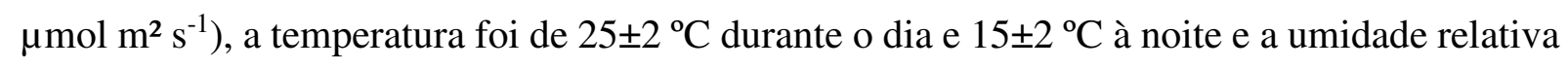
média de $75 \pm 5 \%$ (Figura 4). 


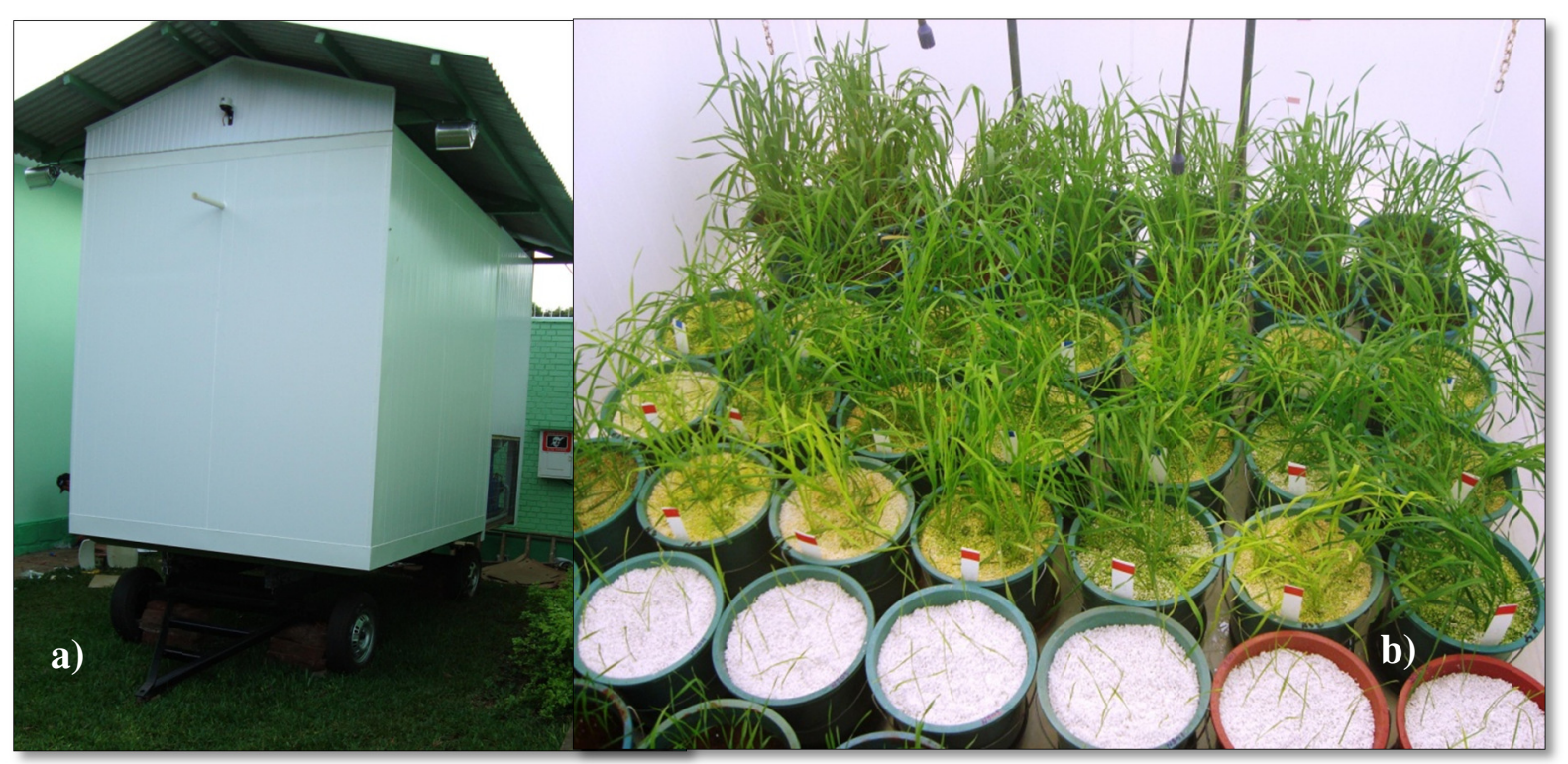

Figura 4 - Câmara de crescimento das plantas de trigo utilizadas como doadoras das anteras para o experimento (a). Distribuição dos vasos contendo as plantas de trigo da cultivar Genaro dentro da câmara (b)

\subsection{Tratamentos}

Os tratamentos foram constituídos de cinco doses de nitrogênio $(25 \%, 50 \%, 100 \%, 150 \%$ e $200 \%$ ) (APÊNDICE A) e cinco doses de boro (25\%, 50\%, 100\%, 150\% e 200\%) (APÊNDICE B) utilizando como base a solução descrita por Sarruge (1975). Visando estabelecer o adequado equilíbrio nos componentes da solução para o experimento de avaliação do efeito do nitrogênio, fez-se a correção da concentração de potássio através da adição de cloreto de potássio $(\mathrm{KCl})$ nas concentrações de $1.750,1.500,1000,500$ e $0 \mu \mathrm{mol} \mathrm{L}^{-1}$ para cada uma das soluções de nitrogênio, respectivamente. Os valores de $\mathrm{pH}$ e condutividade elétrica de cada solução podem ser visualizados na Tabela 1. 
Tabela 1 - Valores de $\mathrm{pH}$ e condutividade elétrica das soluções nutritivas utilizadas nos experimentos para o cultivo das plantas de trigo da cultivar Genaro doadoras de anteras

\begin{tabular}{ccc|ccc}
\hline $\begin{array}{c}\text { Nitrogênio na } \\
\text { solução }(\%)^{*}\end{array}$ & $\mathrm{pH}$ & $\begin{array}{c}\text { Condutividade } \\
\text { elétrica }(\mathrm{mS} / \mathrm{cm})\end{array}$ & $\begin{array}{c}\text { Boro na } \\
\text { solução } \\
(\%)^{*}\end{array}$ & $\mathrm{pH}$ & $\begin{array}{c}\text { Condutividade } \\
\text { elétrica }(\mathrm{mS} / \mathrm{cm})\end{array}$ \\
\hline 25 & 5,52 & 2,104 & 25 & 5,57 & 2826 \\
50 & 5,51 & 2437 & 50 & 5,54 & 2821 \\
100 & 5,59 & 2708 & 100 & 5,61 & 2798 \\
150 & 5,55 & 3640 & 150 & 5,57 & 2802 \\
200 & 5,55 & 4034 & 200 & 5,56 & 2787 \\
\hline
\end{tabular}

* Concentrações dos nutrientes tendo por base a solução nutritiva descrita por Sarruge (1975)

A aplicação das soluções nutritivas (tratamentos) foi feita três vezes por semana à base de $200 \mathrm{ml}$ por vaso por aplicação e, sempre que necessária, fez-se a suplementação da irrigação das plantas com água destilada e deionizada tomando o cuidado para manter cheio o aparador de cada vaso.

A distribuição dos vasos dentro da câmara de crescimento foi feita através de sorteio e cada experimento (bloco) continha um vaso com 15 plantas para cada uma das concentrações avaliadas, totalizando 10 vasos por experimento (bloco) (cinco de nitrogênio e cinco de boro). O delineamento do experimento foi em blocos casualizados no tempo, totalizando oito blocos.

\subsection{Determinação dos componentes do rendimento em trigo}

Os componentes do rendimento analisados no ponto de coleta para a cultura de anteras foram: número de colmos por planta; diâmetro $(\mathrm{mm})$ e comprimento do colmo principal $(\mathrm{cm})$; comprimento $(\mathrm{cm})$ e largura $(\mathrm{cm})$ da folha bandeira do colmo principal; área da folha bandeira do colmo principal $\left(\mathrm{cm}^{2}\right)$; massa fresca da parte aérea $(\mathrm{g})$, massa seca da parte aérea $(\mathrm{g})$; concentração de macronutrientes $\left(\mathrm{g} \mathrm{kg}^{-1}\right)$ e de micronutrientes $\left(\mathrm{mg} \mathrm{kg}^{-1}\right)$ do tecido vegetal da parte aérea dos colmos coletados; distância da folha bandeira (FB) até o último nó (UN) $(\mathrm{cm})$ e comprimento da espiga $(\mathrm{cm})$, o qual foi determinado pela medida do intervalo compreendido entre a base da inserção do primeiro par de espiguetas até a ponta da última espigueta da espiga, sem contar as aristas e sem levar em consideração a fertilidade das flores. A determinação das variáveis que envolveram comprimento e largura foi feita utilizando-se uma régua milimétrica na porção mais larga da lâmina foliar e a determinação do diâmetro do caule foi feita com 
auxílio de paquímetro no momento da coleta das espigas. A área da folha bandeira principal foi calculada pela equação (1).

$$
\mathrm{AFB}=\frac{\text { comprimento } \mathrm{x} \text { largura }}{2}
$$

Os macronutrientes e micronutrientes foram determinados no Laboratório de Análise de Tecidos Vegetais da área de Nutrição Mineral de Plantas do Departamento de Ciência do Solo, da ESALQ/USP, em Piracicaba, SP. Um grupo de plantas foi cultivado até a maturação para determinar potencial de produção nas soluções através do número e massa (g) de grãos colhidos, massa de palha (g) e massa total da parte aérea (g) (grãos + palha). As análises das variáveis que envolveram a determinação da massa seca da parte aérea ocorreram após o material permanecer em estufa a $55^{\circ} \mathrm{C}$ por 72 horas.

Para todas as variáveis foram analisadas de três a cinco plantas em cada bloco. A homogeneidade da variância (homocedasticidade) foi testada pelo teste de Box e Cox (1964), o qual indica a necessidade de transformação dos dados sempre que os mesmos não apresentam homogeneidade da variância. Os dados foram submetidos à análise de regressão e sempre que o modelo quadrático apresentou significância, calculou-se o ponto de máxima eficiência (PME) das concentrações da solução para a variável através da equação (2).

$$
P M E=\frac{-b}{2 c}
$$

3.4 Determinação do teor de clorofila

A quantidade de clorofila das plantas foi determinada de acordo com o método descrito por WELLBURN (1994), o qual consistiu em colocar $500 \mathrm{mg}$ da folha bandeira fresca em 10 $\mathrm{ml}$ de solução de acetona a 80\%, no escuro, por 24 horas. Decorrido esse tempo coletou-se 1 $\mathrm{ml}$ do extrato, o qual foi diluído em $9 \mathrm{ml}$ de acetona 80\%. Em seguida efetuou-se a leitura em espectrofotômetro nos comprimentos de onda para absorbância de 470, 646 e $663 \mathrm{~nm}$. Todas as leituras foram realizadas em triplicata. $\mathrm{O}$ teor de clorofila em $\mathrm{mg} \mathrm{g}^{-1}$ de material fresco foi estimado pela equação (3) para clorofila a, equação (4) para clorofila b e equação (5) para clorofila total, conforme Wellburn (1994).

$$
\begin{aligned}
& \mathrm{C}_{\mathrm{a}}=12,25 \times A_{(663)}-2,79 \times A_{646} \\
& \mathrm{C}_{\mathrm{b}}=20,13 \times A_{646}-5,03 \times A_{663} \\
& C_{a+b}=\frac{1000 \times A_{(470)}-3,27 C_{a}-104 C_{b}}{198}
\end{aligned}
$$


Para cada extração da clorofila foram utilizadas as folhas bandeira de no mínimo três plantas. Os resultados foram submetidos à análise de variância e regressão.

3.5 Determinação do acúmulo de graus-dias (GD)

A determinação do acúmulo de graus-dia teve por objetivo verificar a existência interação entre a nutrição e o desenvolvimento das plantas doadoras de anteras, principalmente, no que diz respeito à sua influência sobre o padrão para a coleta das espigas, visando a obtenção de uma metodologia não dependente do aspecto morfológico da planta. Para tanto, foram estabelecidos três pontos de análise adaptando-se à metodologia descrita por Rodrigues et al. (2011): emergência (EM), espigueta terminal (ET) e coleta (COL). Para o período de emergência foi estabelecido como temperatura basal $2,12^{\circ} \mathrm{C}$ e esse período constou da data de semeadura até a emergência completa das plântulas, para o período até espigueta terminal a temperatura basal foi de $4,65^{\circ} \mathrm{C}$, e constou da emergência completa das plântulas até o estádio de espigueta terminal e para o ponto de coleta a temperatura basal foi de $8,44^{\circ} \mathrm{C}$ e constou do estádio de espigueta terminal até o dia da coleta das plantas para o plaqueamento das anteras e/ou sua fixação para análise dos micrósporos.

Após a determinação da duração em dias de cada estádio morfológico, foi calculada a duração total do ciclo (em dias) das plantas doadoras das anteras. Em seguida, calculou-se o número diário de graus-dia (GD) acumulados, subtraindo-se a temperatura basal (para o estádio fenológico correspondente), da média diária da temperatura obtida na câmara de crescimento. O total dos graus-dias acumulados (GD total), da semeadura até o ponto de coleta, foi obtido pela soma dos totais diários dos três estádios fenológicos estudados para cada concentração de nitrogênio e de boro. Para a determinação do estádio de espigueta terminal, foram analisadas cinco plantas por vaso e para o estádio de ponto de coleta foram consideradas todas as plantas utilizadas para o plaqueamento e/ou fixação das anteras visando à determinação do desenvolvimento dos micrósporos. As médias obtidas em cada experimento (bloco) foram submetidas à análise de variância e comparadas pelo teste de Tukey com $P \leq 0,05$.

3.6 Determinação do estádio de desenvolvimento dos micrósporos

Para a avaliação dos micrósporos, primeiramente, foi feita a determinação das variáveis avaliadas para os componentes do rendimento e em seguida, cortou-se o colmo 
principal da planta. Determinou-se a distância total entre a folha bandeira (FB) e o nó de inserção do pedúnculo da espiga (último nó do colmo - UN) e também a distância entre a folha bandeira e a penúltima folha do colmo (folha bandeira menos um - FB-1). Em seguida, foi realizada a coleta da espiga, a determinação de seu comprimento, sua identificação e sua fixação em solução fixadora composta por álcool a 99\% e ácido acético glacial na proporção 3:1 (v/v). Após 24 horas da fixação, as espigas foram transferidas e armazenadas em solução de álcool a $70 \%$ onde aguardaram até o momento da realização da avaliação citológica.

A avaliação do estádio de desenvolvimento dos micrósporos foi feita através da análise microscópica, a qual constou da observação de uma lâmina contendo o conteúdo de três anteras (uma flor), coradas com carmim acético e analisada em microscópio óptico Zeiss modelo Primo Star no Laboratório de Cultura de Tecidos e Citogenética Vegetal do IFRS-Câmpus Sertão e Nykon modelo Eclipse E200 no CYNGELA (Cytogenomics and Epigenetics Laboratory) da ESALQ/USP. Para cada espiga fixada, confeccionaram-se três lâminas, sendo uma da região apical, uma da região mediana e a outra da região basal da espiga. Em cada lâmina contaramse os 100 primeiros micrósporos visualizados em aumento de 400 vezes, os quais foram classificados em uma das seguintes categorias: tétrade, mononucleado central, mononucleado periférico, binucleado e pólen “ $P$ ”. Desta forma, para cada espiga analisada foram contadas 300 células. Ao todo, foram contados 21.000 micrósporos de 70 espigas de plantas oriundas dos tratamentos com doses de nitrogênio e 20.100 micrósporos de 67 espigas de plantas oriundas dos tratamentos com doses de boro totalizando, 41.100 micrósporos.

Foi avaliada a influência das concentrações dos nutrientes (nitrogênio e boro), a posição das flores dentro da espiga (apical, mediana e basal) e a possível interação entre as concentrações de nutrientes e a posição das flores na espiga no desenvolvimento dos micrósporos. Os dados foram submetidos à análise de variância e as diferenças comparadas pelo teste não paramétrico de Friedman $(P \leq 0,05)$.

Foi avaliada também a influência das concentrações de nitrogênio e boro no desenvolvimento dos micrósporos de acordo com o deslocamento da folha bandeira menos um ao logo da distância total entre a folha bandeira e o último nó. Para tanto, foram estabelecidas três faixas de deslocamento partindo da folha bandeira: 0-40\% de deslocamento, de $>40-60 \%$ de deslocamento e $>60 \%$ de deslocamento. Os valores obtidos foram analisados pelo teste não paramétrico de Kruscal Wallis $(P \leq 0,05)$. 
3.7 Determinação do número de estruturas embriogênicas formadas

Quando as plantas atingiram o padrão morfológico para a coleta das espigas visando à cultura de anteras, conforme Wheatley, Marsolais e Kasha, (1986); Grando e Moraes-Fernandes (1989) ou seja, FB-1 a um terço da FB, fez-se a coleta das espigas para a cultura de anteras. Para tanto, foi cortado o colmo principal da planta e após a determinação dos parâmetros referentes aos componentes do rendimento retirou-se a FB e da FB-1 e a espiga foi colocada em becker contendo água destilada, sempre tomando cuidado de manter a espiga coberta pela palha para evitar contaminações e mantendo a identificação do tratamento a que ela pertencia. Após a coleta, as espigas foram levadas ao laboratório onde se efetuou a desinfestação das mesmas com álcool a 70\% e algodão esterilizado sob fluxo laminar.

Após a desinfestação, foi efetuada a abertura do colmo, a exposição da espiga e a confecção de uma lâmina de microscopia contendo as três anteras de uma flor da região central da espiga, para averiguação do estádio de desenvolvimento citológico dos micrósporos. De acordo com o resultado (micrósporos mononucleados centrais e/ou periféricos), foi feita a inoculação das anteras no meio de indução para o cultivo in vitro.

3.8 Meios de cultura utilizado para o cultivo das anteras de trigo

Para a realização da cultura de anteras utilizou-se o meio indução Batata II conforme descrito por Moraes-Fernandes e Picard (1983), (APÊNDICE C), na íntegra e com algumas modificações como pode ser observado abaixo.

- Meio I constou do meio de Batata II;

- Meio II, constou dos mesmos componentes do meio de indução Batata II distinguindo-se pelo fato de ter a substituição dos $2 \mathrm{mg} \mathrm{L}^{-1}$ de $2,4-\mathrm{D}$ por $2 \mathrm{mg} \mathrm{L}^{-1}$ de ácido benzoico;

- Meio III constou dos mesmos componentes do meio de indução Batata II distinguindo-se pelo fato de ter a substituição dos $2 \mathrm{mg} \mathrm{L}^{-1}$ de $2,4-\mathrm{D}$ por $4 \mathrm{mg} \mathrm{L}^{-1}$ de ácido benzoico;

- Meio IV constou dos componentes do meio de indução Batata II com a substituição do $2 \mathrm{mg}$.L de 2,4-D por $1 \mathrm{mg} \mathrm{L}^{-1}$ de ANA mais $1 \mathrm{mg} \mathrm{L}^{-1}$ de ácido benzoico. $\mathrm{O} \mathrm{pH}$ de todos os meios foi ajustado para 5,8 antes da autoclavagem. 
Feita a exposição da espiga, foi realizada a inoculação das anteras de cada uma das quatro fileiras de flores da espiga em um meio diferente de modo que a mesma espiga tenha sido inoculada nos quatro meios. Durante a identificação das placas, foi mantida a origem (tratamento da planta mãe), a fileira e o meio que estava sendo utilizado. Em seguida, as placas, contendo as anteras, foram envolvidas em papel alumínio (no escuro) e submetidas ao tratamento de frio, o qual constou da permanência das mesmas em geladeira a $4^{\circ} \mathrm{C}$ por cinco dias. Terminado o tratamento de frio, as placas foram levadas para a câmara de cultivo a $25 \pm 2^{\circ} \mathrm{C}$, onde permaneceram no escuro até a formação das estruturas embriogênicas (60 dias). A avaliação do número de estruturas embriogênicas formadas foi feita após 75 dias de cultivo in vitro. Para tanto foi considerado como estrutura embriogênica os calos formados a partir das anteras plaqueadas nos meios de indução que apresentavam diâmetro maior ou igual a $1 \mathrm{~mm}$ no momento da avaliação. Os resultados foram submetidos à análise de variância da regressão e Tukey $(P \leq 0,05)$ e a análise de correlação entre as variáveis dos componentes do rendimento com estruturas embriogênicas tanto para o nitrogênio quanto para o boro.

Após a avaliação, as estruturas embriogênicas foram transferidas para o meio de regeneração (APENDICE C) e as plântulas regeneradas foram aclimatizadas em câmara de crescimento e mantidas sob as mesmas condições das plantas doadoras. Para confirmação do seu nível de ploidia, fez-se a análise citogenética das células somáticas de ponta de raiz, as quais foram fixadas e coradas com Feulgen e as lâminas visualizadas em microscópio óptico Zeiss Axiostar Plus em aumento de 400 e 1000x. 


\section{RESULTADOS}

4.1 Resultados dos experimentos com cinco concentrações de nitrogênio na solução de Sarruge (1975).

\subsubsection{Componentes do rendimento}

As concentrações de nitrogênio utilizadas no experimento promoveram diferenças marcantes no visual e no crescimento e desenvolvimento das plantas de trigo da cultivar Genaro doadoras de anteras (Figura 5).

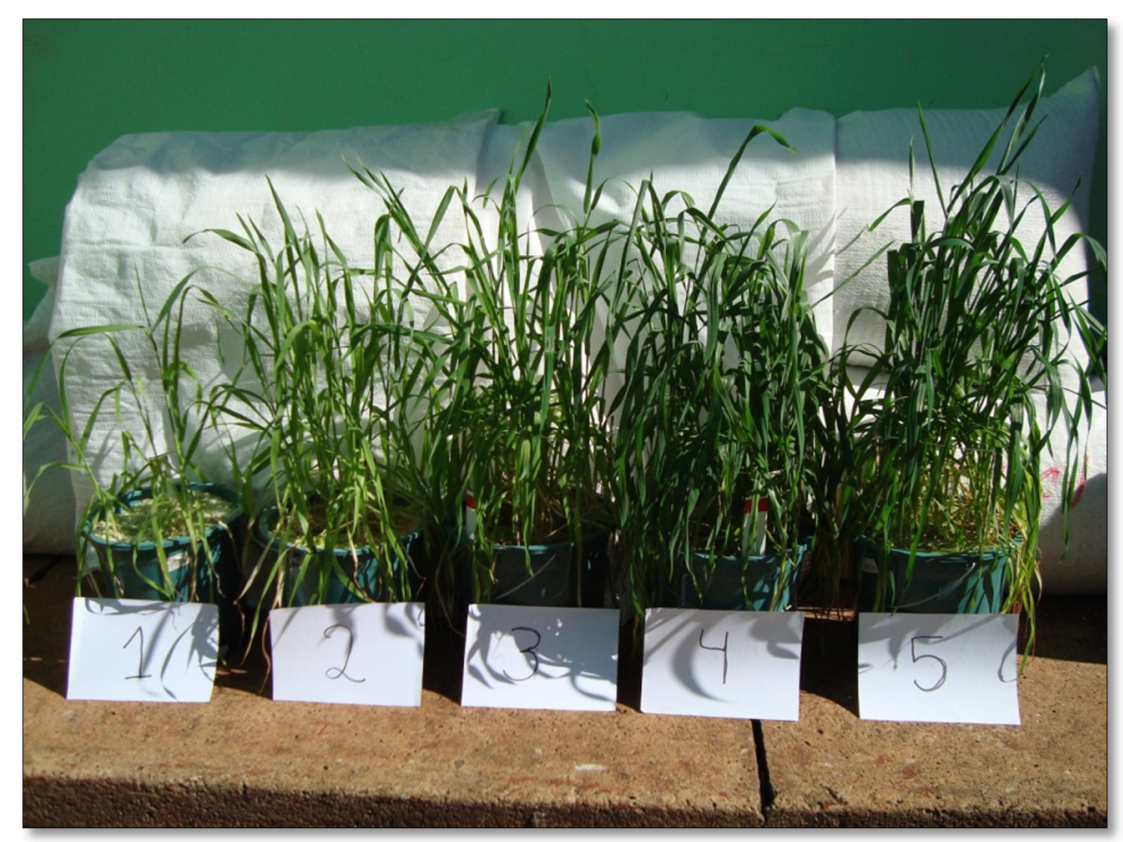

Figura 5 - Plantas de trigo da cultivar Genaro produzidas em solução de Sarruge (1975) com cinco concentrações de nitrogênio. Os números 1 a 5 indicam as doses $25 \%, 50 \%, 100 \%, 150 \%$ e $200 \%$ de nitrogênio, respectivamente

O número de colmos foi influenciado pelas doses de nitrogênio em que as plantas foram cultivadas. As plantas cultivadas nas concentrações 100\%, 150\% e 200\% de nitrogênio em relação à solução de Sarruge (1975), não diferiram estatisticamente, enquanto que as cultivadas sob as concentrações $25 \%$ e $50 \%$ de nitrogênio apresentaram os menores índices de número de colmos. O ponto de máxima eficiência da solução para essa variável ficou em 137\% de nitrogênio em relação à solução de Sarruge (1975) (Figura 6a). 
Quanto ao diâmetro dos colmos, apenas as plantas submetidas à concentração $25 \%$ de nitrogênio em relação à solução de Sarruge (1975) foram influenciadas significativamente pelo tratamento, as quais apresentaram os menores valores para a variável (Figura 6b).

Com relação ao comprimento do colmo principal esta variável foi influenciada pela concentração de nitrogênio da solução, sendo que os maiores valores foram registrados para as plantas cultivadas na solução com $200 \%$ da concentração de nitrogênio e os menores valores foram registrados na solução de $25 \%$ de nitrogênio em relação à solução de Sarruge (1975). O ponto de máxima eficiência da solução para essa variável ficou em $159 \%$ de nitrogênio em relação à solução de Sarruge (1975) (Figura 6c).

A partir da concentração $100 \%$ de nitrogênio em relação à solução de Sarruge (1975), as plantas tiveram os maiores valores de comprimento da folha bandeira e não apresentaram diferença significativa entre si. Porém, as plantas cultivadas com as soluções contendo $25 \%$ e $50 \%$ de nitrogênio apresentaram os menores valores de comprimento de folha bandeira. O ponto máximo de eficiência da solução calculado para essa variável foi de $131 \%$ de nitrogênio em relação à solução de Sarruge (1975) (Figura 7a).

A largura da folha bandeira não apresentou diferença significativa nas concentrações $100 \%, 150 \%$ e 200\% de nitrogênio em relação à solução de Sarruge (1975). Porém, as plantas da concentração $25 \%$ de nitrogênio apresentaram o menor valor para a variável, seguidas das plantas da solução com 50\% de nitrogênio em relação à solução de Sarruge (1975). Isto pode indicar que, até certo ponto, o nitrogênio interfere na largura da folha bandeira; a partir daí, essa variável segue o padrão genético da cultivar. O ponto de máxima eficiência da solução calculado para essa variável foi de aproximadamente 139\% de nitrogênio em relação à solução de Sarruge (1975) (Figura 7b).

Os maiores valores de área da folha bandeira foram registrados em plantas submetidas a $100 \%, 150 \%$ e $200 \%$ de nitrogênio da solução de Sarruge (1975), os quais foram significativamente superiores aos valores obtidos nas plantas que receberam $25 \%$ e $50 \%$ de nitrogênio na solução de Sarruge (1975). O ponto de máxima eficiência da solução para a variável foi de $133 \%$ de nitrogênio em relação à solução de Sarruge (1975) (Figura 7c).

Os maiores valores de massa fresca da parte aérea (MFPA) foram obtidos nas plantas cultivadas na solução de Sarruge (1975) com as concentrações de nitrogênio de100\%, 150\% e $200 \%$. O menor desempenho para a variável foi registrado pelas plantas que foram cultivadas com a concentração de $25 \%$ de nitrogênio na solução. O ponto de máxima eficiência da solução foi de $135 \%$ de nitrogênio em relação à solução de Sarruge (1975) (Figura 8a). 
Os maiores valores para massa seca da parte aérea (MSPA) foram verificados nas soluções com as concentrações de nitrogênio de $100 \%$, 150\% e $200 \%$ em relação à solução de Sarruge (1975), enquanto o menor valor para esta variável foi verificado na concentração $25 \%$ de nitrogênio. O ponto de máxima eficiência da solução calculado foi de $136 \%$ de nitrogênio em relação à solução de Sarruge (1975) (Figura 8a).

O teor de clorofila na folha bandeira das plantas coletadas no ponto para a cultura de anteras aumentou linearmente de acordo com o aumento da concentração de nitrogênio na solução de Sarruge (1975). Portanto, a solução com 200\% de nitrogênio apresentou a maior concentração de clorofila no tecido (Figura 8b).

A distância entre a folha bandeira e o último nó do colmo (FB-UN) representa uma variável importante para a obtenção do padrão morfológico de coleta das espigas para o plaqueamento das anteras (WHEATLEY; MARSOLAIS; KASHA, 1986). Houve aumento linear na distância entre a folha bandeira e o último nó do colmo de acordo com o aumento das doses de nitrogênio na solução de Sarruge (1975) (Figura 8c).

Quanto ao comprimento da espiga, não houve diferença significativa entre as concentrações de nitrogênio utilizadas no experimento $(P=0,0729)$. 
a)

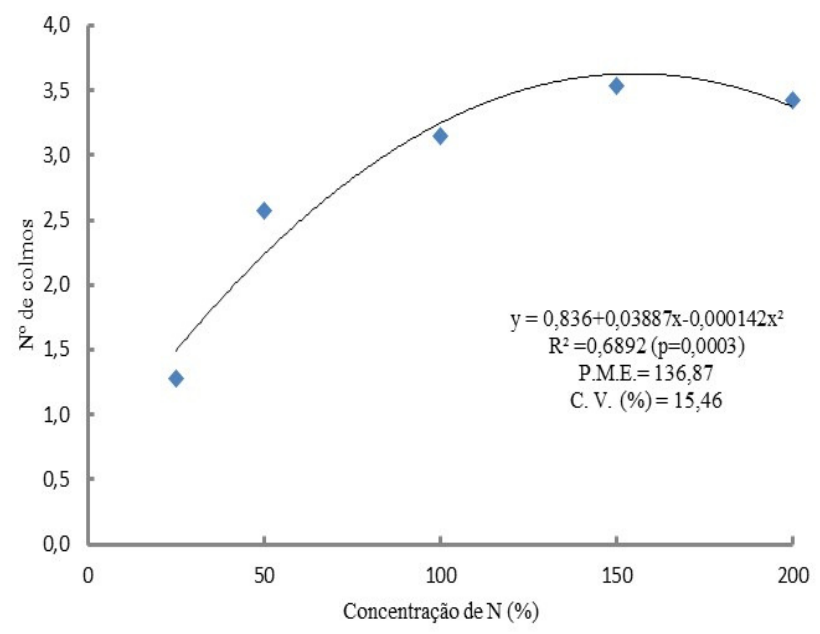

b)

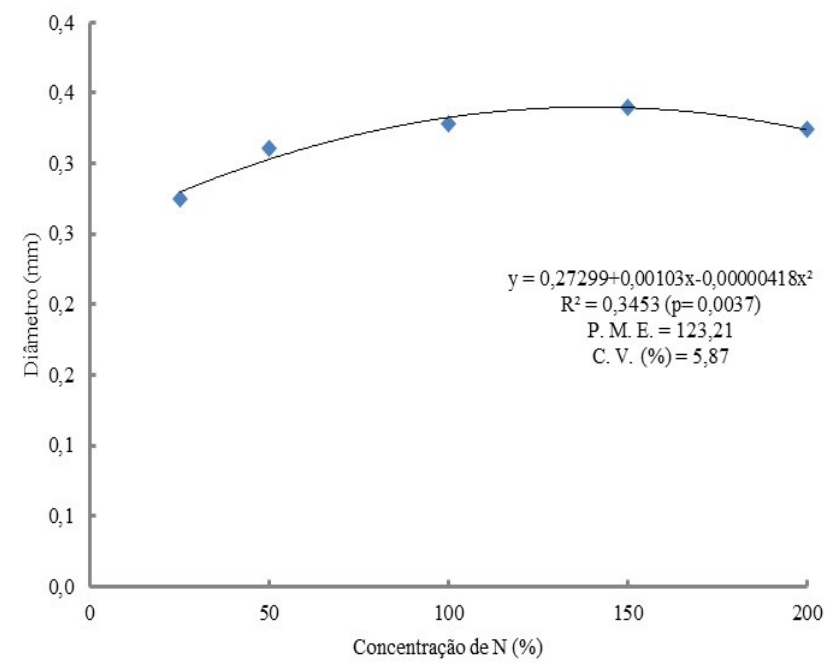

c)

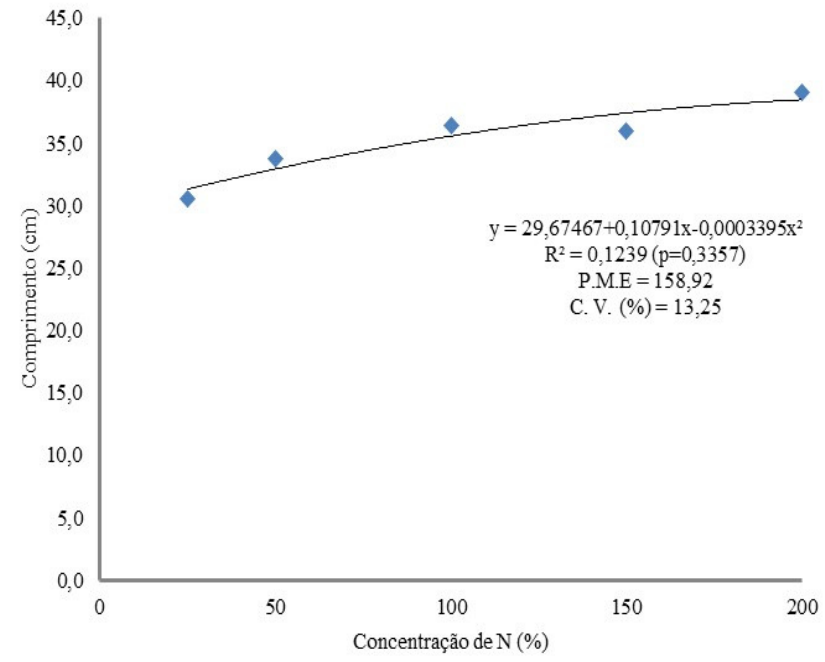

Figura 6 - Componentes do rendimento em plantas de trigo da cultivar Genaro produzidas em solução de Sarruge (1975), com cinco concentrações de nitrogênio expressos em: número de colmos por planta (a); diâmetro do colmo principal (b) e comprimento do colmo principal (c) 
a)

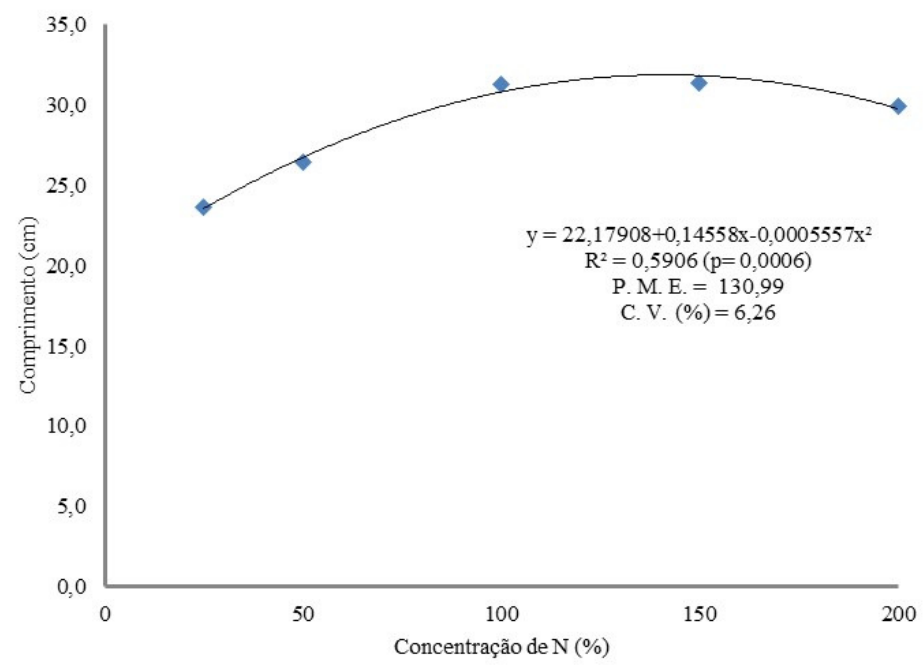

b)

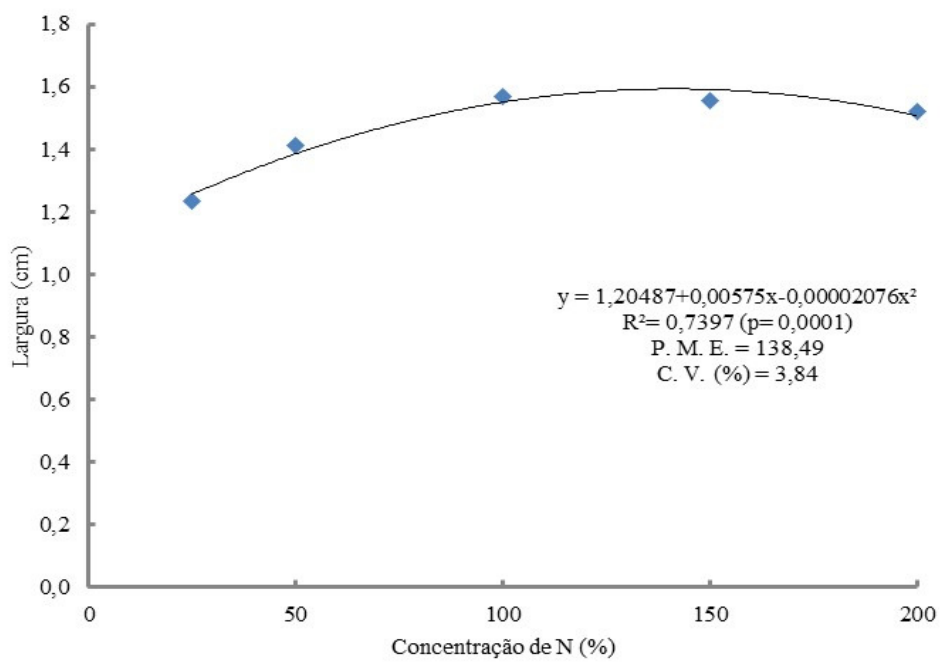

c)

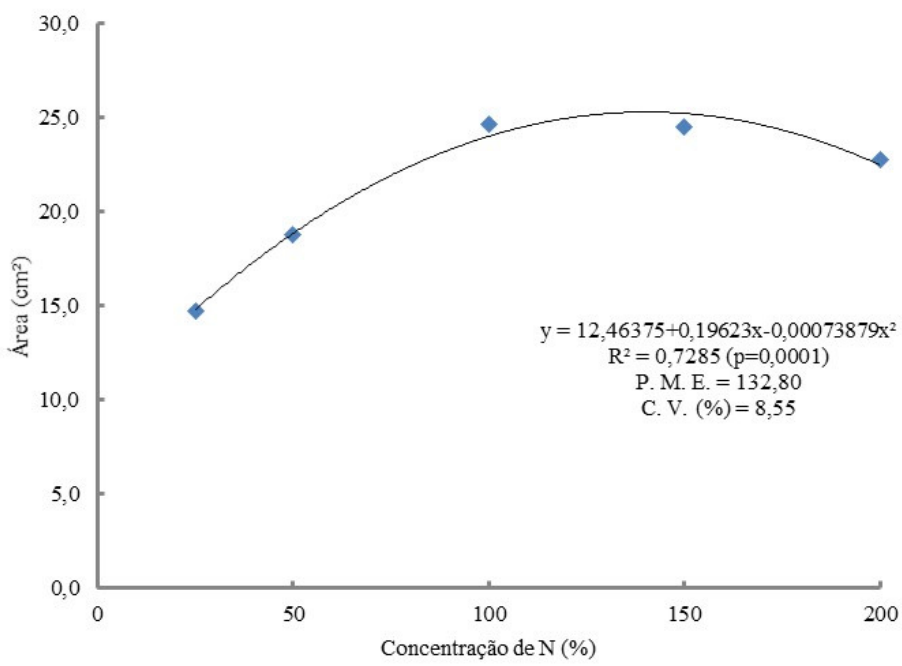

Figura 7 - Componentes do rendimento em plantas de trigo da cultivar Genaro produzidas em solução de Sarruge (1975), com cinco concentrações de nitrogênio expressas em: comprimento da folha bandeira do colmo principal (a); largura da folha bandeira do colmo principal (b) e área da folha bandeira do colmo principal (c) 
a)

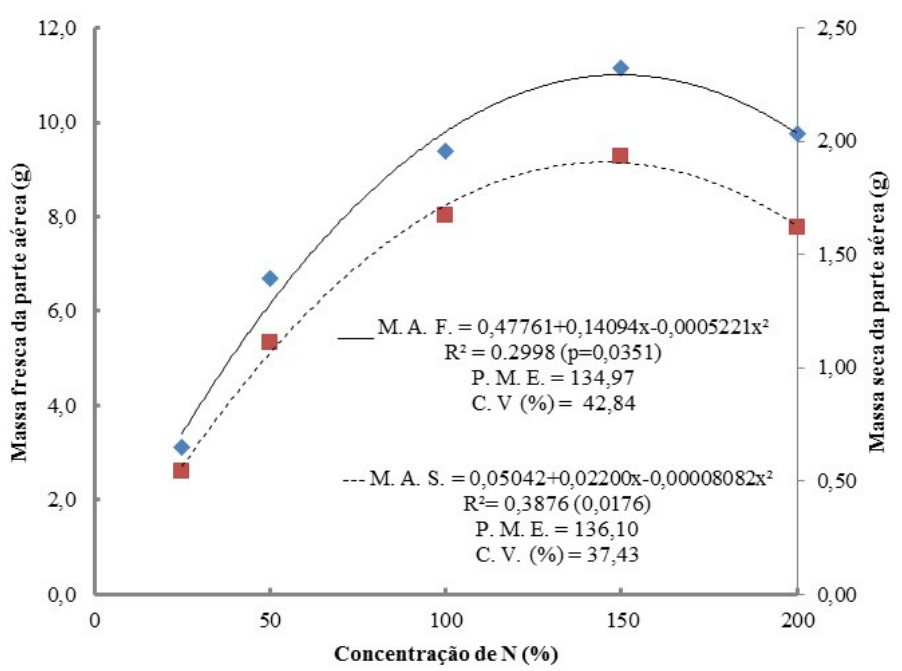

b)

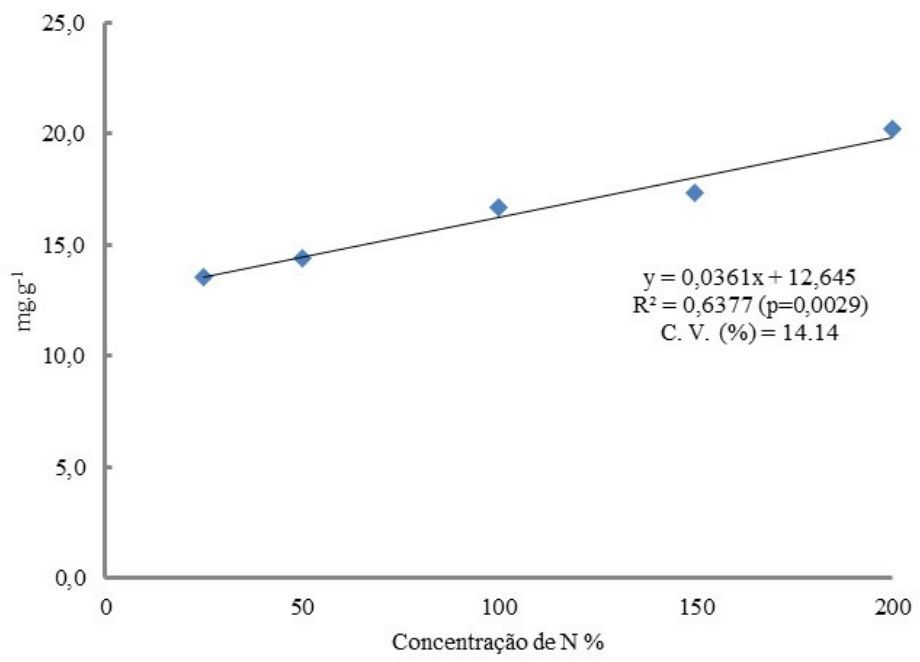

c)

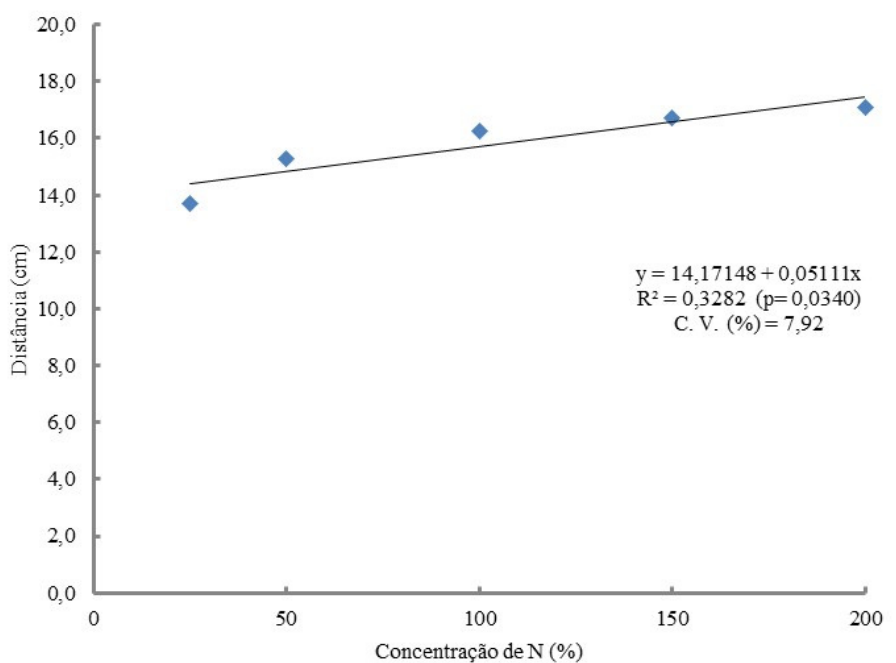

Figura 8 - Componentes do rendimento em plantas de trigo da cultivar Genaro produzida em solução de Sarruge (1975), com cinco concentrações de nitrogênio expressas em: massa fresca da parte aérea e massa seca da parte aérea (a); teor de clorofila da folha bandeira do colmo principal (b) e distância entre a folha bandeira e o último nó do colmo principal (c) 
As maiores concentrações de nitrogênio total na parte aérea foram observadas nas plantas cultivadas nas concentrações com 100\%, 150\% e 200\% de nitrogênio, as quais diferiram estatisticamente das cultivadas nas concentrações $25 \%$ e $50 \%$ de nitrogênio que apresentaram os menores teores desse nutriente nos tecidos (Tabela 2).

Tabela 2 - Concentração de nitrogênio total na parte aérea das plantas de trigo da cultivar Genaro cultivadas em solução nutritiva descrita por Sarruge (1975), com cinco concentrações de nitrogênio, no momento do isolamento das espigas para cultura de anteras

\begin{tabular}{cc}
\hline $\begin{array}{c}\text { Nitrogênio na solução de } \\
\text { Sarruge }(1975)(\%)\end{array}$ & Teor de nitrogênio no tecido $\left(\mathrm{g} \mathrm{kg}^{-1}\right)^{(1)}$ \\
\hline 25 & $26,68 \mathrm{~b}$ \\
50 & $30,75 \mathrm{~b}$ \\
100 & $37,08 \mathrm{a}$ \\
150 & $38,05 \mathrm{a}$ \\
200 & $37,81 \mathrm{a}$ \\
\hline $\mathrm{n}$ & 4 \\
\hline C. V. (\%) & 6,8 \\
\hline Valor de $P$ & 0,0001 \\
\hline
\end{tabular}

(1) Médias seguidas da mesma letra não diferem estatisticamente pelo teste de Tukey $(P \leq 0,05)$

As plantas cultivadas a partir da concentração $50 \%$ de nitrogênio não apresentaram diferença significativa no número médio e massa de grãos colhidos por planta. As plantas cultivadas com a concentração de $25 \%$ de nitrogênio, em relação à solução de Sarruge (1975), apresentaram os menores valores para número médio e massa de grãos por planta e diferiram estatisticamente das demais (Tabela 3).

A massa de palha seca nas plantas cultivadas a partir da concentração $100 \%$ de nitrogênio não diferiu estatisticamente da média obtida nas plantas cultivadas nas concentrações de $150 \%$ e de $200 \%$ de nitrogênio em relação à solução de Sarruge (1975). O menor valor para a variável massa de palha seca foi observado nas plantas oriundas da solução a $25 \%$ de nitrogênio em relação à solução de Sarruge (1975) (Tabela 3).

Para a massa média da parte aérea total (grãos + palha) as plantas cultivadas nas concentrações 100\%, 150\% e 200\% de nitrogênio em relação à solução de Sarruge (1975), não apresentaram diferenças significativas. As plantas cultivadas nas concentrações $50 \%$ não diferiram das médias obtidas nas plantas cultivadas com $100 \%$ e 200\%: de nitrogênio. As plantas cultivadas com a concentração $25 \%$ de nitrogênio em relação à solução de Sarruge 
(1975), diferiram das demais, por apresentarem os menores valores, respectivamente (Tabela $3)$.

Tabela 3 - Número e massa de grãos, massa seca da palha e massa seca da parte aérea total de plantas de trigo da cultivar Genaro cultivadas em solução de Sarruge (1975), com cinco concentrações de nitrogênio, colhidas após a maturação fisiológica

\begin{tabular}{ccclc}
\hline $\begin{array}{c}\text { Nitrogênio na } \\
\text { solução de Sarruge } \\
(1975)(\%)\end{array}$ & $\begin{array}{c}\text { Número } \\
\text { médio de } \\
\text { grão por }_{\text {planta }^{(1)}}\end{array}$ & $\begin{array}{c}\text { Massa média de } \\
\text { grãos colhidos } \\
(\mathrm{g})^{(1)}\end{array}$ & $\begin{array}{c}\text { Massa média } \\
\text { palha seca }(\mathrm{g})^{(1)}\end{array}$ & $\begin{array}{c}\text { Massa média } \\
\text { parte aérea } \\
\text { total }(\mathrm{g})^{(1)}\end{array}$ \\
\hline 25 & $22,75 \mathrm{~b}$ & $0,98 \mathrm{~b}$ & $0,79 \mathrm{c}$ & $1,78 \mathrm{c}$ \\
50 & $55,44 \mathrm{a}$ & $2,44 \mathrm{a}$ & $1,76 \mathrm{bc}$ & $4,26 \mathrm{~b}$ \\
100 & $73,78 \mathrm{a}$ & $2,50 \mathrm{a}$ & $2,81 \mathrm{ab}$ & $5,87 \mathrm{ab}$ \\
150 & $78,67 \mathrm{a}$ & $3.17 \mathrm{a}$ & $3,57 \mathrm{a}$ & $6,74 \mathrm{a}$ \\
200 & $63,14 \mathrm{a}$ & $2,44 \mathrm{a}$ & $2,74 \mathrm{ab}$ & $5,19 \mathrm{ab}$ \\
\hline $\mathrm{n}$ & 42 & 42 & 42 & 42 \\
\hline C. V. $(\%)$ & 37,8 & 38,6 & 1,3 & 32,8 \\
\hline Valor de $P$ & 0,001 & 0,001 & 0,001 & 0,001 \\
\hline
\end{tabular}

${ }^{(1)}$ Médias seguidas da mesma letra não diferem estatisticamente pelo teste de Tukey $P \leq 0,05$

\subsubsection{Determinação dos graus-dias (GD) acumulados}

Com relação ao acúmulo de graus-dias (GD), embora tenha ocorrido diferença visual entre as plantas cultivadas nas concentrações de nitrogênio da solução de Sarruge (1975), esta não foi suficiente para provocar diferença significativa entre os tratamentos, nos três estádios fenológicos de desenvolvimento analisados (emergência (EM), espigueta terminal (ET) e ponto de coleta (PC)). Da mesma forma, não houve diferença significativa no total de graus-dias acumulados da semeadura até o ponto de coleta (Tabela 4).

A duração do tempo de cultivo das plantas em dias, desde a semeadura até o ponto de coleta para a cultura de anteras (FB-1 a 1/3 da distância total entre a FB e o UN), mostrou diferenças significativas em relação às doses de nitrogênio nas quais as plantas doadoras foram cultivadas. As plantas cultivadas com as soluções 150\%, 200\% e 100\% de nitrogênio, apresentaram ciclo mais longo do que aquelas submetidas às doses $25 \%$ de nitrogênio em relação à solução de Sarruge (1975) (Tabela 4). 
Tabela 4 - Número médio de graus-dias (GD) acumulados nos estádios fenológicos: emergência, espigueta terminal e ponto de coleta; média do total de graus-dias acumulados no período e média em dias, para atingir o ponto de coleta das espigas para a cultura de anteras em plantas de trigo da cultivar Genaro, cultivadas em cinco concentrações de nitrogênio a partir da solução de Sarruge (1975)

\begin{tabular}{clllll}
\hline $\begin{array}{l}\text { Nitrogênio na } \\
\text { solução de Sarruge } \\
(1975)(\%)\end{array}$ & $\begin{array}{c}\text { GD } \\
\text { emergência }\end{array}$ & $\begin{array}{c}\text { GD espigueta } \\
\text { terminal }^{(1)}\end{array}$ & $\begin{array}{c}\text { GD } \\
\text { coleta }^{(1)}\end{array}$ & $\begin{array}{c}\text { GD } \\
\text { total }^{(1)}\end{array}$ & $\begin{array}{c}\text { Dias para } \\
\text { coleta }^{(1)}\end{array}$ \\
\hline 25 & $100,1 \mathrm{a}$ & $619,1 \mathrm{a}$ & $224,1 \mathrm{a}$ & $943,4 \mathrm{a}$ & $68,1 \mathrm{bc}$ \\
50 & $100,1 \mathrm{a}$ & $627,8 \mathrm{a}$ & $216,8 \mathrm{a}$ & $944,7 \mathrm{a}$ & $67,5 \mathrm{c}$ \\
100 & $100,1 \mathrm{a}$ & $630,9 \mathrm{a}$ & $220,0 \mathrm{a}$ & $951,0 \mathrm{a}$ & $69,7 \mathrm{ab}$ \\
150 & $100,1 \mathrm{a}$ & $645,0 \mathrm{a}$ & $226,7 \mathrm{a}$ & $971,8 \mathrm{a}$ & $70,8 \mathrm{a}$ \\
200 & $100,1 \mathrm{a}$ & $650,6 \mathrm{a}$ & $213,1 \mathrm{a}$ & $963,4 \mathrm{a}$ & $69,9 \mathrm{ab}$ \\
\hline $\mathrm{n}$ & 5 & 5 & 5 & 5 & 7 \\
\hline C. V. $(\%)$ & 1,3 & 3,5 & 10,0 & 1,9 & 1,8 \\
\hline Valor de $P$ & 0,9999 & 0,2006 & 0,8683 & 0,0990 & 0.0003 \\
\hline
\end{tabular}

(1) Médias seguidas da mesma letra não diferem estatisticamente pelo teste de Tukey $(P \leq 0,05)$

\subsubsection{Determinação do estádio de desenvolvimento dos micrósporos}

As categorias de micrósporos avaliadas nesse experimento são mostradas na Figura 9.

Com relação ao estádio de desenvolvimento dos micrósporos e a formação de polens "P", houve diferença significativa nos valores obtidos das plantas cultivadas nas concentrações de nitrogênio em relação à solução de Sarruge (1975) para todas as variáveis estudadas e também, para a influência da posição da flor dentro da espiga, para os estádios de tétrade e mononucleado periférico. Porém, não foi constatada significância para a interação concentração de nitrogênio na solução $\times$ posição da flor na espiga (Tabela 5) no que diz respeito ao desenvolvimento dos micrósporos.

As plantas cultivadas nas soluções com a concentração 100\% de nitrogênio apresentaram maior número de células em tétrade porém, não diferiram das médias obtidas nas plantas cultivadas nas concentrações $150 \%$ e 200\% de nitrogênio em relação à solução descrita por Sarruge (1975). As plantas cultivadas na solução 200\% de nitrogênio não diferiram também das cultivadas nas soluções com $25 \%$ e $50 \%$ de nitrogênio em relação à solução descrita por Sarruge (1975) (Tabela 5). Com relação ao estádio mononucleado central, observou-se que exceto as plantas produzidas na concentração $100 \%$ de nitrogênio, que apresentou menor número, as plantas produzidas nas demais concentrações não apresentaram diferenças significativas entre si (Tabela 5). 


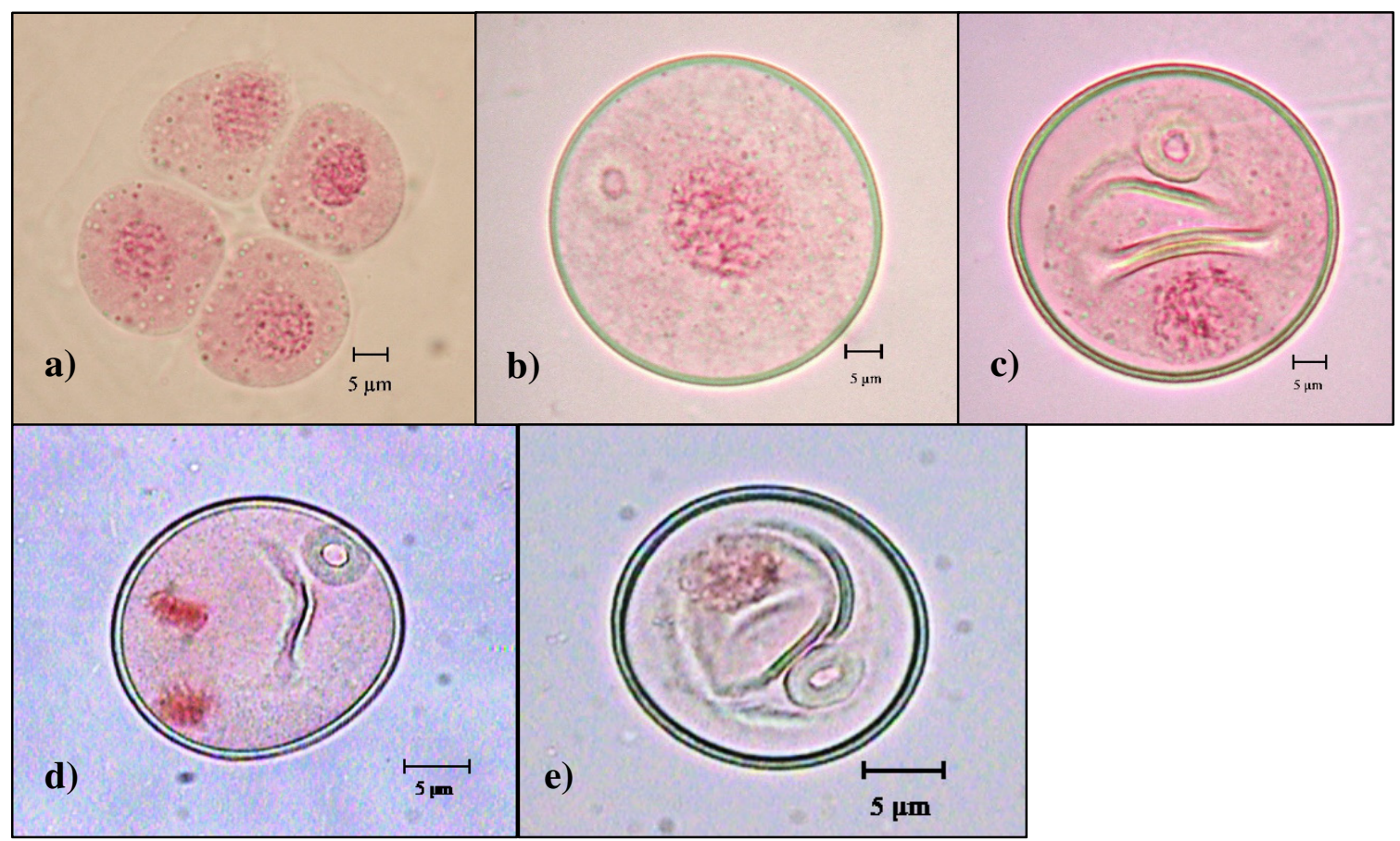

Figura 9 - Micrósporos oriundos de plantas de trigo da cultivar Genaro em diferentes estádios de desenvolvimento e pólen "P" visualizados em 400x de aumento. Tétrade (a); Mononucleado central (b); Mononucleado periférico (c); Binucleado (inicial) (d) e Pólen "P” (e)

Para o estádio mononucleado periférico, observaram-se diferenças significativas entre plantas produzidas nas concentrações de nitrogênio na solução, sendo que plantas cultivadas nas menores concentrações de nitrogênio $(50 \%$ e $25 \%)$ apresentaram os maiores números de células nesse estádio o menor número médio de células mononucleadas periféricas ocorreu nas plantas cultivadas na dose $100 \%$ de nitrogênio em relação à solução de Sarruge (1975). Para o estádio binucleado houve diferença significativa entre as médias obtidas das plantas cultivadas na concentração de nitrogênio $50 \%$, as plantas cultivadas nas demais concentrações não diferiram entre si (Tabela 5). Isso demonstra que as concentrações menores de nitrogênio promoveram o desenvolvimento mais rápido ao longo do experimento.

No que diz respeito ao pólen "P", as plantas cultivadas na concentração $100 \%$ de nitrogênio em relação à solução de Sarruge (1975), apresentaram o menor número médio desse tipo de células e diferiram significativamente das demais. Nesse caso, deve-se observar que os polens "P" não correspondem a um estádio de desenvolvimento no ciclo da formação do grão de pólen, mas sim, um tipo especial de pólen, cuja formação acredita-se estar mais relacionada com o genótipo da espécie do que com a influência de fatores ambientais tal como, a nutrição (Tabela 5). 
Tabela 5 - Número médio de micrósporos por estádio de desenvolvimento e índice de polens "P" em plantas de trigo da cultivar Genaro, cultivadas em cinco concentrações de nitrogênio a partir da solução de Sarruge (1975), até o ponto de coleta das espigas para a cultura de anteras

\begin{tabular}{clllll}
\hline $\begin{array}{l}\text { Nitrogênio na } \\
\text { solução de Sarruge } \\
(1975)(\%)\end{array}$ & \multicolumn{5}{c}{ Estádio de desenvolvimento dos micrósporos } \\
\cline { 2 - 6 } & Tétrade & $\begin{array}{l}\text { Mononucleado } \\
\text { central }\end{array}$ & $\begin{array}{l}\text { Mononucleado } \\
\text { Periférico }\end{array}$ & Binucleado & $\begin{array}{l}\text { Pólen } \\
\text { "P”" }\end{array}$ \\
\hline 25 & $6,05 \mathrm{c}$ & $10,25 \mathrm{a}$ & $9,28 \mathrm{ab}$ & $8,00 \mathrm{ab}$ & $8,44 \mathrm{ab}$ \\
50 & $5,67 \mathrm{c}$ & $8,28 \mathrm{ab}$ & $11,31 \mathrm{a}$ & $9,25 \mathrm{a}$ & $9,89 \mathrm{a}$ \\
100 & $11,25 \mathrm{a}$ & $5,03 \mathrm{~b}$ & $5,81 \mathrm{c}$ & $7,58 \mathrm{~b}$ & $5,17 \mathrm{~b}$ \\
150 & $9,42 \mathrm{ab}$ & $7,19 \mathrm{ab}$ & $6,17 \mathrm{bc}$ & $7,58 \mathrm{~b}$ & $7,94 \mathrm{ab}$ \\
200 & $7,61 \mathrm{bc}$ & $9,25 \mathrm{a}$ & $7,44 \mathrm{bc}$ & $7,58 \mathrm{~b}$ & $8,56 \mathrm{ab}$ \\
\hline $\mathrm{n}$ & 18 & 18 & 18 & 18 & 18 \\
\hline C. V. $(\%)$ & 35,5 & 50,6 & 46,1 & 20,7 & 56,0 \\
\hline Valor de $P$ & 0,0001 & 0,0029 & 0,0001 & 0,0129 & 0,0351 \\
\hline
\end{tabular}

* Médias seguidas da mesma letra na coluna não diferem pelo teste de Friedman a $(P \leq 0,05)$

Houve diferença significativa quanto ao estádio de desenvolvimento dos micrósporos nas três regiões da espiga das plantas cultivadas nas concentrações de nitrogênio. Para a variável tétrade, as posições apical e basal da espiga apresentaram as maiores médias de células e não diferiram estatisticamente entre si, enquanto na posição mediana da espiga, obteve-se número médio de células significativamente menor quando comparado com a posição basal (Tabela 6).

Por outro lado, enquanto se observou maior número de micrósporos no estádio mononucleado periférico na região mediana das espigas, as regiões apical e basal mostraram os menores números de micrósporos nesse estádio (Tabela 6).

Tabela 6 - Número médio de micrósporos em diferentes estádios de desenvolvimento em três regiões da espiga de plantas de trigo cultivar Genaro, cultivadas em cinco concentrações de nitrogênio na solução de Sarruge (1975), no ponto de coleta para a cultura de anteras

\begin{tabular}{clc}
\hline Região da espiga & \multicolumn{2}{c}{ Estádio de desenvolvimento dos micrósporos } \\
\cline { 2 - 3 } & Tétrade & Mononucleado periférico \\
\hline Apical & $8,28 \mathrm{ab}$ & $7,52 \mathrm{~b}$ \\
Mediana & $6,73 \mathrm{~b}$ & $9,88 \mathrm{a}$ \\
Basal & $8,98 \mathrm{a}$ & $6,60 \mathrm{~b}$ \\
\hline $\mathrm{n}$ & 30 & 30 \\
\hline C. V. $(\%)$ & 35,5 & 46,1 \\
\hline Valor de $P$ & 0,0098 & 0,0030 \\
\hline * Médias na coluna seguidas da mesma letra não diferem pelo teste de Friedman $P \leq 0,05$
\end{tabular}


Em função das análises citológicas realizadas no decorrer dos experimentos, observouse que foram coletadas espigas cujo padrão morfológico (distância FB-1 já percorrida) não foi obedecido. Assim, realizou-se a análise da influência das concentrações de nitrogênio em três faixas de deslocamento da FB-1 em relação à distância total entre a folha bandeira e o último nó (até $40 \%$; $>40 \%$ até $60 \%$ e $>60 \%$ ) a qual indicou que as concentrações de nitrogênio influenciaram significativamente todas as variáveis (estádios de desenvolvimento dos micrósporos + índice de pólen P) no primeiro terço percorrido pela folha bandeira menos um, ou seja, até $40 \%$. Com relação ao segundo terço (>40 - 60\%), houve diferença significativa apenas para o estádio de tétrade. Com relação à última porção (>60\%), não houve diferença significativa entre as doses de nitrogênio avaliadas em relação à solução de Sarruge (1975).

\subsubsection{Produção de estruturas embriogênicas androgenéticas}

O efeito das concentrações de nitrogênio foi significativo na resposta à formação de estruturas embriogênicas androgenéticas por cultura de anteras (Figura 11a, 11b e 11c). As maiores médias de formação de estruturas embriogênicas foram obtidas a partir das anteras coletadas das plantas, cujas soluções nutritivas utilizadas em seu cultivo apresentaram maior concentração de nitrogênio em relação à solução descrita por Sarruge (1975). Por outro lado, as anteras oriundas das plantas cultivadas nas menores concentrações $(25 \%$ e $50 \%$ de nitrogênio), apresentaram as menores médias de formação de estruturas embriogênicas em todos os meios utilizados (Figura 10). A análise de variância não mostrou diferenças significativas entre os diferentes blocos para essa variável. 


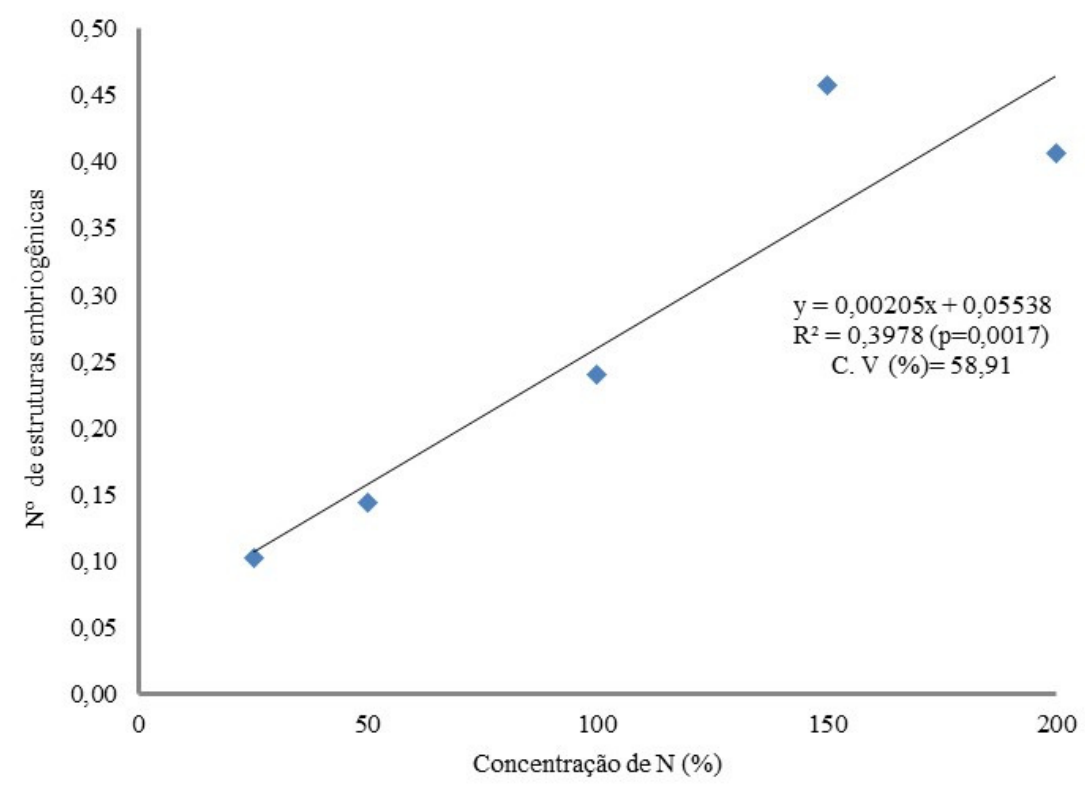

Figura 10 - Número de estruturas embriogênicas formadas pelas anteras cultivadas em quatro meios de cultura, em função das cinco concentrações de nitrogênio presentes na solução de Sarruge (1975) utilizadas no cultivo das plantas doadoras de anteras

Foi observada diferença significativa no número médio de anteras plaqueadas oriundas das plantas cultivadas nas concentrações de nitrogênio. As plantas cultivadas na concentração $200 \%$ de nitrogênio tiveram maior número de anteras plaqueadas e as cultivadas na concentração 25\% de nitrogênio em relação à solução de Sarruge (1975), o menor número de anteras plaqueadas. As plantas cultivadas nas demais concentrações de nitrogênio na solução não apresentaram diferença significativa entre si (Tabela 7).

Tabela 7 - Número médio de anteras plaqueadas oriundas das plantas de trigo, da cultivar Genaro, cultivadas em cinco concentrações de nitrogênio a partir da solução de Sarruge (1975)

\begin{tabular}{cl}
\hline $\begin{array}{c}\text { Concentração nitrogênio na } \\
\text { solução de Sarruge (1975) }(\%)\end{array}$ & Anteras plaqueadas $^{(1)}$ \\
\hline 25 & $17,63 \mathrm{c}$ \\
50 & $20,38 \mathrm{~b}$ \\
100 & $21,30 \mathrm{~b}$ \\
150 & $21,51 \mathrm{~b}$ \\
200 & $23,28 \mathrm{a}$ \\
\hline $\mathrm{n}$ & 28 \\
\hline C. V. $(\%)$ & 10.7 \\
\hline Valor de $P$ & 0.0001 \\
\hline
\end{tabular}

${ }^{(1)}$ Médias na coluna seguidas da mesma letra não diferem pelo teste de Tukey $P \leq 0,05$ 
Com relação à influência dos meios de cultura, houve diferença significativa entre a média de estruturas embriogênicas obtida no Meio I o qual apresentou a maior taxa de formação de estruturas embriogênicas androgenéticas seguido do Meio IV que não diferiu dos meios II e III que apresentaram as menores taxas de formação estruturas embriogênicas androgenéticas (Tabela 8). Contudo, não foi verificada significância para a interação concentrações de nitrogênio $\times$ meio de cultura em que as anteras foram plaqueadas, demonstrando que essas variáveis influenciaram de modo independente na formação das estruturas e

Tabela 8 - Número médio de estruturas embriogênicas androgenéticas formadas nos meios de cultura utilizados para o cultivo das anteras oriundas das plantas de trigo, da cultivar Genaro, produzidas em cinco concentrações de nitrogênio a partir da solução de Sarruge (1975)

\begin{tabular}{|c|c|}
\hline Meio & Estruturas embriogênicas $^{(1)}$ \\
\hline $\mathrm{I}^{(2)}$ & $0,65 \mathrm{a}$ \\
\hline $\mathrm{II}^{(3)}$ & $0,16 b$ \\
\hline $\mathrm{III}^{(4)}$ & $0,15 b$ \\
\hline $\mathrm{IV}^{(5)}$ & $0,35 \mathrm{ab}$ \\
\hline $\mathrm{n}$ & 25 \\
\hline C.V. (\%) & 37 \\
\hline Valor de $P$ & 0,0074 \\
\hline \multicolumn{2}{|c|}{$\begin{array}{l}\text { (1) Médias na coluna seguidas da mesma letra não diferem pelo teste de Tukey } P \leq 0,05 \\
\text { (2) Batata II } \\
\text { (3) Batata II s/ 2,4-D + } 2 \mathrm{mg} \mathrm{L}^{-1} \text { de ácido benzoico } \\
\text { (4) Batata II s/ 2,4-D + } 4 \mathrm{mg} \mathrm{L}^{-1} \text { de ácido benzoico } \\
{ }^{(5)} \text { Batata II s/ 2,4-D + } 1 \mathrm{mg} \mathrm{L}^{-1} \mathrm{ANA}+1 \mathrm{mg} \mathrm{L}^{-1} \text { de ácido benzoico }\end{array}$} \\
\hline
\end{tabular}




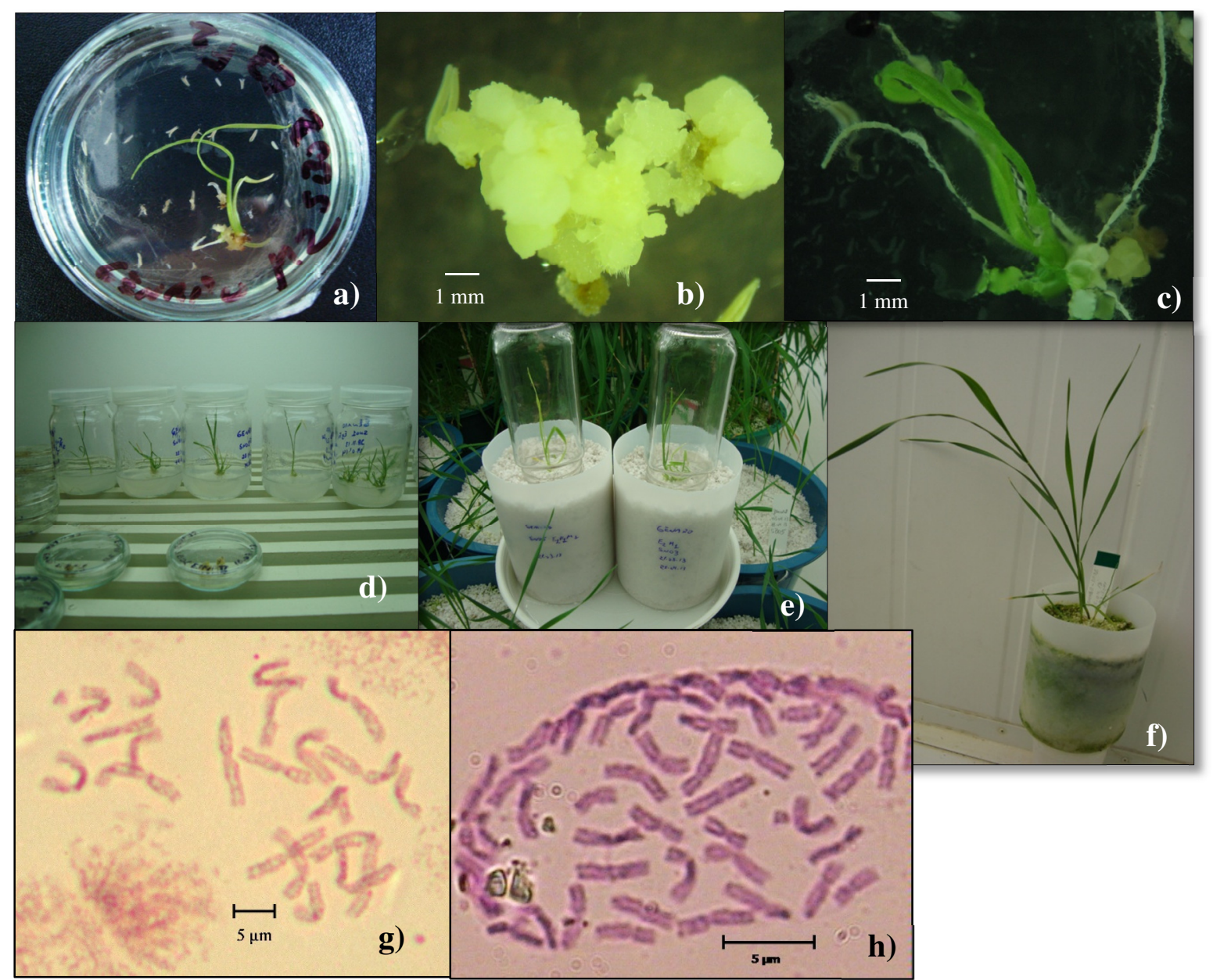

Figura 11 - Plântula haploide de trigo da cultivar Genaro produzida por organogênese direta a partir de anteras plaqueadas no meio de indução (a), estruturas embriogênicas androgenéticas (calo) formadas a partir dos micrósporos de anteras cultivadas no meio de indução (b), início da diferenciação das estruturas embriogênicas androgenéticas em plântulas (c), plântulas haploides regeneradas in vitro (d), aclimatização das plântulas haploides (e), plantas aclimatizadas em câmara de cultivo (f), análise citogenética das plantas regeneradas mostrando número haploide de cromossomos $(\mathrm{n}=3 \mathrm{x}=21)(\mathrm{g})$, análise citogenética de uma planta de trigo mostrando número normal de cromossomos $(2 \mathrm{n}=6 \mathrm{x}=$ 42) aumentados 400x (h)

No experimento para a avaliação de concentrações de nitrogênio a partir da solução de Sarruge (1975) visando ao cultivo de plantas trigo doadoras de anteras, a correlação foi significativa entre as estruturas embriogênicas produzidas e: o número de colmos $(P=0,0080)$; o diâmetro do colmo principal $(P=0,0361)$; o comprimento da folha bandeira $(P=0,0375)$; a largura da folha bandeira $(P=0,0042)$; a área da folha bandeira $(P=0,0262)$; a massa fresca da parte aérea $(P=0,0048)$; a massa seca da parte aérea $(P=0,0205)$ e o teor de clorofila $(P=$ 0,0053).

Ao longo do experimento foram regeneradas 25 plantas (Figura 11d, 11e e 11f), cuja condição haploide foi confirmada (Figura 11g), porém não foi realizada a duplicação 
cromossômica (Figura 11h) nas mesmas e consequentemente, não houve produção de sementes uma vez que não era o objetivo deste trabalho.

4.2 Resultados referentes aos experimentos com cinco concentrações de boro na solução de Sarruge (1975)

\subsubsection{Componentes do rendimento}

Os resultados obtidos para as variáveis fitotécnicas número de colmos, diâmetro do colmo principal, comprimento do colmo principal (Figuras 12a, 12b e 12c), comprimento da folha bandeira (FB), largura da folha bandeira (FB), área da folha bandeira (FB) (Figuras 13a, 13b e 13c), massa fresca da parte aérea (MFPA) e massa seca da parte aérea (MSPA) não apresentaram diferenças estatísticas nas plantas cultivadas com as concentrações de boro na solução nutritiva (Figura 14a).

Foi constatada diferença significativa no teor de clorofila na folha bandeira das plantas cultivadas nas concentrações de boro na solução de Sarruge (1975), porém não foi proporcional ao aumento das concentrações aplicadas. O maior valor foi obtido nas plantas cultivadas no tratamento $100 \%$ de boro seguido das plantas cultivadas nos tratamentos a $25 \%$ e a $200 \%$ de boro em relação à solução descrita por Sarruge (1975), respectivamente. A menor concentração de clorofila foi obtida pelas plantas da solução a 150\% de boro em relação à solução de Sarruge (1975) (Figura 14b). Com relação às variáveis, distância entre FB - UN e comprimento da espiga, também não houve diferença significativa entre as plantas cultivadas nas doses de boro avaliadas (Figura 14c). 
a)

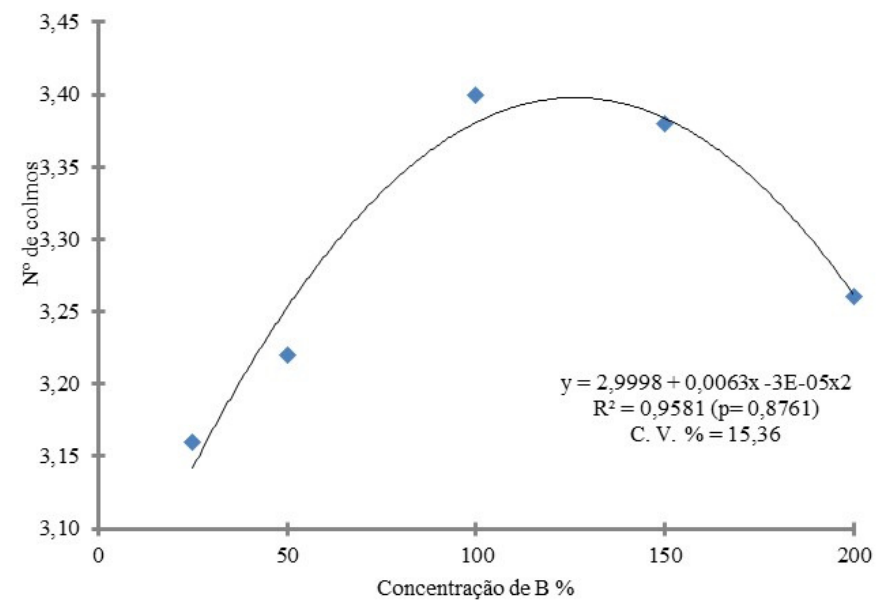

b)

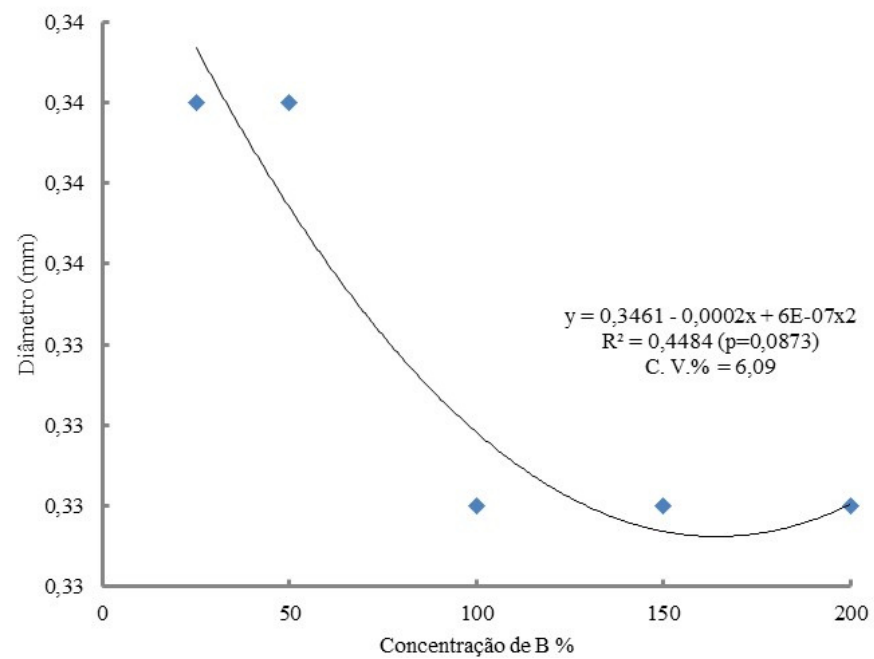

c)

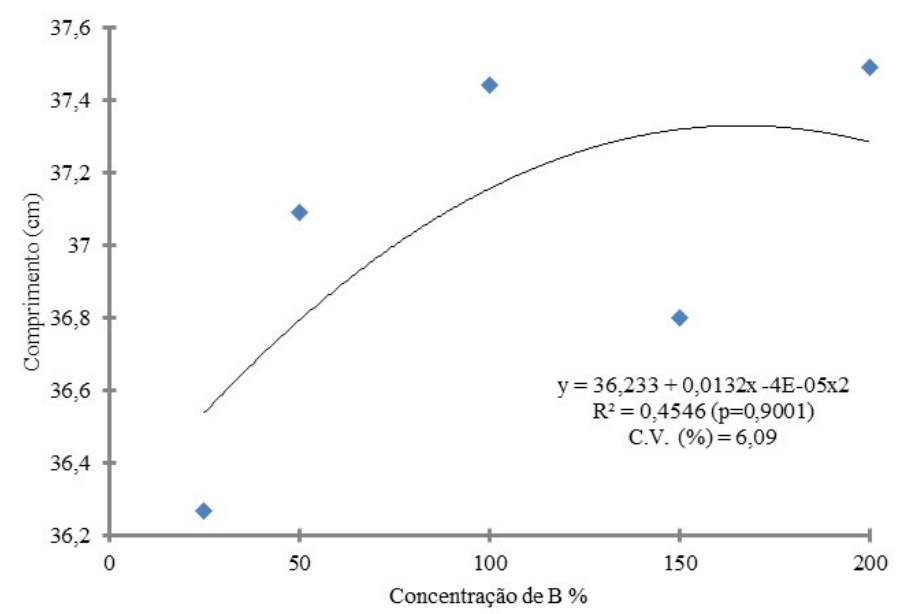

Figura 12 - Componentes do rendimento em plantas de trigo da cultivar Genaro produzidas em solução de Sarruge (1975), com cinco concentrações de boro, expressos em: número de colmos por planta (a); diâmetro do colmo principal (b) e comprimento do colmo principal (c) 
a)

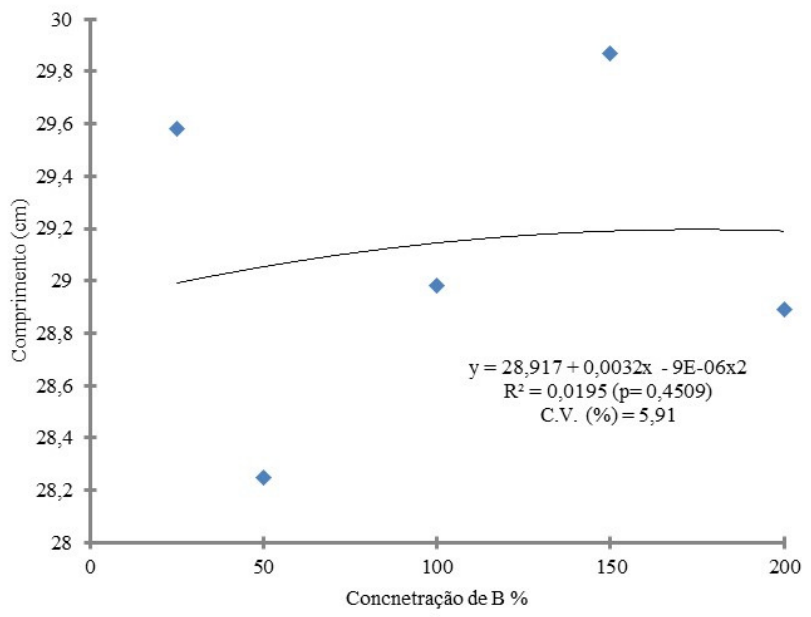

b)

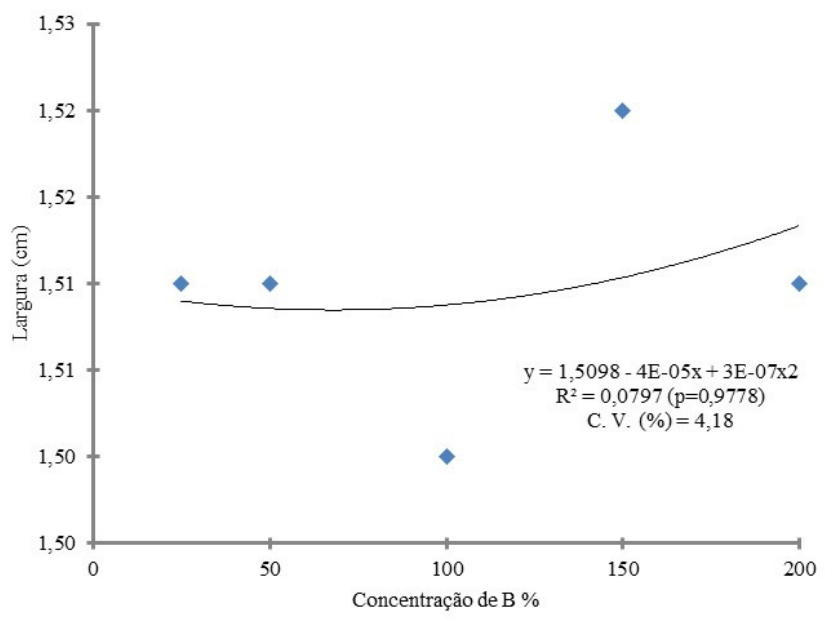

c)

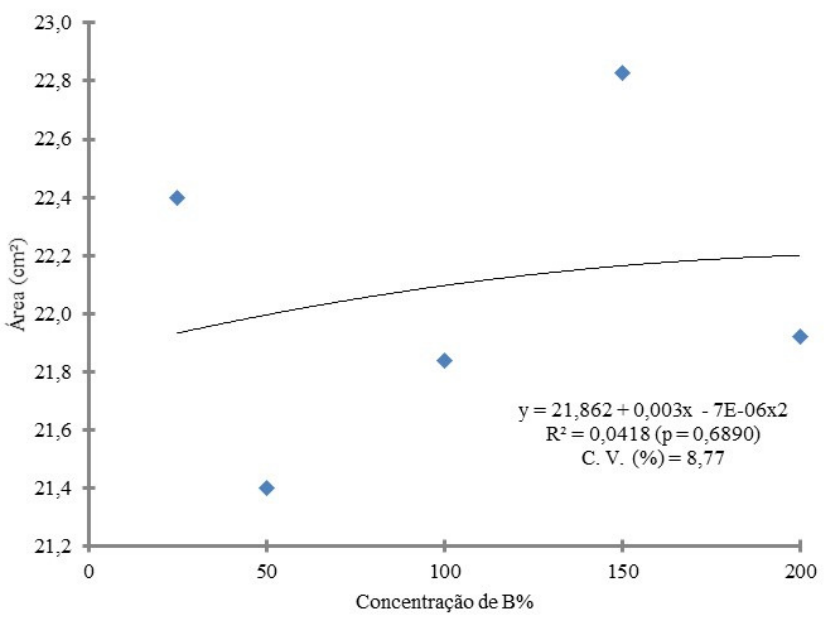

Figura 13 - Componentes do rendimento em plantas de trigo da cultivar Genaro produzidas em solução de Sarruge (1975), com cinco concentrações de boro, expressas em: comprimento da folha bandeira do colmo principal (a); largura da folha bandeira do colmo principal (b) e área da folha bandeira do colmo principal (c) 
a)

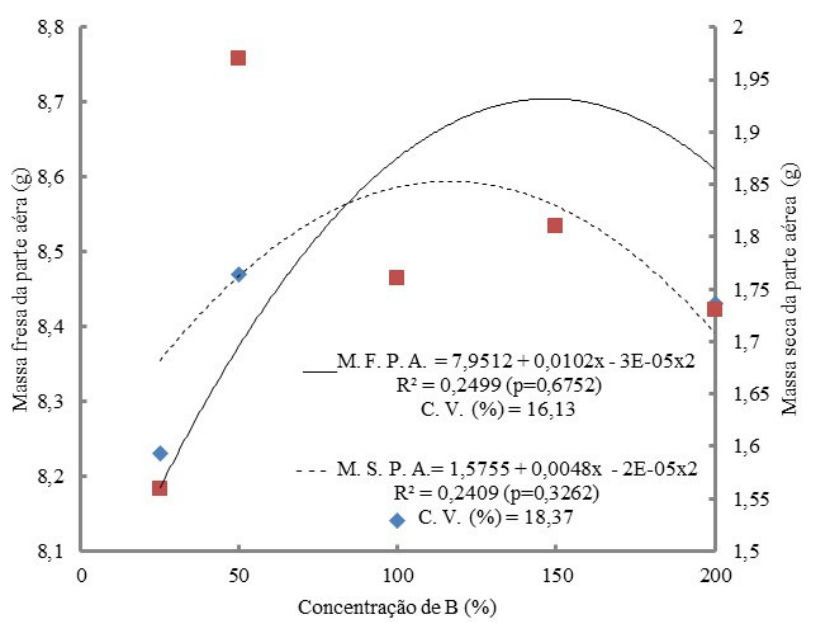

b)

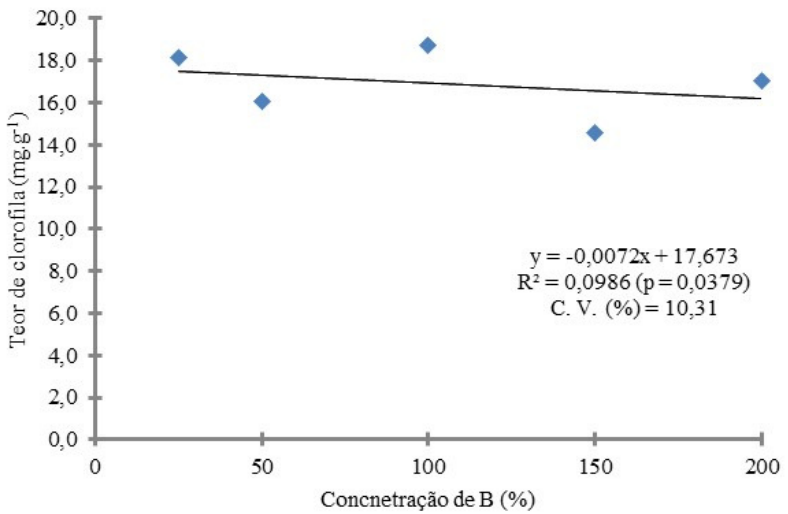

c)

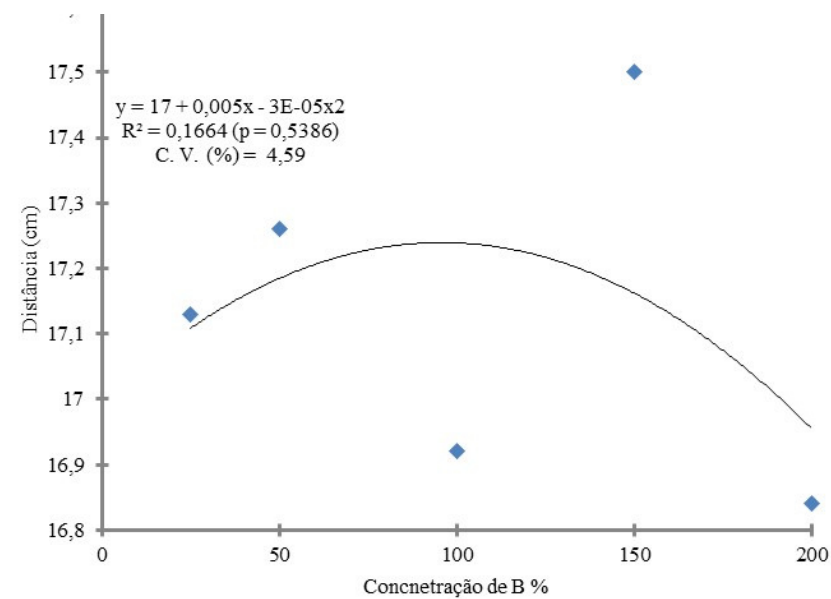

Figura 14 - Componentes do rendimento em plantas de trigo da cultivar Genaro produzidas em solução de Sarruge (1975), com cinco concentrações de boro, expressos em: massa fresca da parte aérea e massa seca da parte aérea (a); teor de clorofila da folha bandeira do colmo principal (b) e distância entre a folha bandeira e o último nó do colmo principal (c) 
A concentração de boro no tecido da parte aérea das plantas doadoras de anteras no momento da coleta mostrou que os maiores valores ocorreram nas concentrações $200 \%, 150 \%$ e $100 \%$ de boro na solução, sendo que os valores relativos a $100 \%$ não diferiram dos valores obtidos pelas plantas das concentrações $50 \%$ e $25 \%$ de boro em relação à solução de Sarruge (1975), que apresentaram os teores mais baixos de boro no tecido da parte aérea, respectivamente (Tabela 9).

Tabela 9 - Concentração de boro total na parte aérea das plantas de trigo, da cultivar Genaro, cultivadas em solução nutritiva descrita por Sarruge (1975), com cinco concentrações de boro, no momento do isolamento das espigas para cultura de anteras

\begin{tabular}{cc}
\hline $\begin{array}{c}\text { Boro na solução de Sarruge } \\
(1975)(\%)\end{array}$ & Teor de boro no tecido $\left(\mathrm{mg} \mathrm{kg}^{-1}\right)^{(1)}$ \\
\hline 25 & $12,10 \mathrm{a}$ \\
50 & $13,68 \mathrm{a}$ \\
100 & $20,92 \mathrm{ab}$ \\
150 & $32,60 \mathrm{~b}$ \\
200 & $36,45 \mathrm{~b}$ \\
\hline $\mathrm{n}$ & 4 \\
\hline C. V. $(\%)$ & 37,21 \\
\hline Valor de $P$ & 0,0030 \\
\hline
\end{tabular}

(1) Médias seguidas da mesma letra não diferem estatisticamente pelo teste de Tukey $(P \leq 0,05)$

Com relação ao número e à massa de grãos colhidos, massa palha seca e a massa média total da parte aérea (grãos + palha) não houve diferença significativa entre as plantas produzidas com concentrações de boro na solução de Sarruge (1975) (Tabela 10). 
Tabela 10 - Número e massa de grãos, massa seca da palha e massa seca da parte aérea total de plantas de trigo da cultivar Genaro cultivadas em solução de Sarruge (1975), com cinco concentrações de boro colhidas após a maturação

\begin{tabular}{|c|c|c|c|c|}
\hline $\begin{array}{l}\text { Boro na solução de } \\
\text { Sarruge (1975) (\%) }\end{array}$ & $\begin{array}{l}\mathrm{N}^{\circ} \text { de grão } \\
\text { colhidos }^{(1)}\end{array}$ & $\begin{array}{l}\text { Massa de grãos } \\
\text { colhidos }(\mathrm{g})^{(1)}\end{array}$ & $\begin{array}{l}\text { Massa palha } \\
\text { seca }(g)^{(1)}\end{array}$ & $\begin{array}{l}\text { Massa da parte } \\
\text { aérea total }(\mathrm{g})^{(1)}\end{array}$ \\
\hline 25 & $76,11 \mathrm{a}$ & $3,33 \mathrm{a}$ & $2,98 \mathrm{a}$ & $6,32 \mathrm{a}$ \\
\hline 50 & $71,89 \mathrm{a}$ & $3,00 \mathrm{a}$ & $3,48 \mathrm{a}$ & $6,39 a$ \\
\hline 100 & $83,89 a$ & $3,06 \mathrm{a}$ & $3,91 \mathrm{a}$ & $6,74 a$ \\
\hline 150 & $88,50 \mathrm{a}$ & $3,95 a$ & $3,47 a$ & $7,42 \mathrm{a}$ \\
\hline 200 & $76,56 a$ & $3,20 \mathrm{a}$ & $2,90 \mathrm{a}$ & $6,14 a$ \\
\hline $\mathrm{n}$ & 44 & 44 & 44 & 44 \\
\hline C.V. (\%) & 35,3 & 40,8 & 34,36 & 33,47 \\
\hline Valor de $P$ & 0,839 & 0,596 & 0,606 & 0,789 \\
\hline
\end{tabular}

(1) Médias seguidas da mesma letra não diferem estatisticamente pelo teste de Tukey $P \leq 0,05$

4.2.2 Determinação dos graus-dias (GD) acumulados

Com relação ao acúmulo de graus-dias (GD), embora tenha ocorrido diferença visual no desenvolvimento entre as plantas cultivadas nas concentrações de boro da solução de Sarruge (1975), esta não foi suficiente para provocar diferença significativa entre os tratamentos, nos três estádios fenológicos de desenvolvimento analisados (emergência, espigueta terminal e ponto de coleta). Da mesma forma, não houve diferença significativa no total de graus-dias acumulados da semeadura até o ponto de coleta (Tabela 11).

Não houve diferença significativa no ciclo médio em dias das plantas cultivadas nas concentrações de boro desde a semeadura até o ponto de coleta (FB-1 a 1/3 da distância total entre a FB e o UN) (Tabela 11). 
Tabela 11 - Número médio de graus-dias (GD) acumulados nos estádios fenológicos: emergência, espigueta terminal e ponto de coleta; média do total de graus-dias acumulados no período e média em dias, para atingir o ponto de coleta das espigas para a cultura de anteras de trigo da cultivar Genaro cultivadas em cinco concentrações de boro na solução de Sarruge (1975)

\begin{tabular}{clllll}
\hline $\begin{array}{c}\text { Concentração } \\
\text { de Boro na } \\
\text { solução (\%) }\end{array}$ & \begin{tabular}{l} 
Graus-Dias $_{\text {Emergência }}{ }^{(1}$ \\
\hline 25
\end{tabular} & $\begin{array}{l}\text { Graus-Dias } \\
\text { Espigueta } \\
\text { Terminal }^{(1)}\end{array}$ & $\begin{array}{l}\text { Graus-Dias } \\
\text { Coleta }^{(1)}\end{array}$ & $\begin{array}{l}\text { Graus-Dias } \\
\text { Total }^{(1)}\end{array}$ & $\begin{array}{l}\text { Dias de } \\
\text { cultivo }^{(1)}\end{array}$ \\
\hline 50 & $100,1 \mathrm{a}$ & $639,7 \mathrm{a}$ & $242,4 \mathrm{a}$ & $977,0 \mathrm{a}$ & $71,7 \mathrm{a}$ \\
100 & $100,1 \mathrm{a}$ & $637,1 \mathrm{a}$ & $233,9 \mathrm{a}$ & $971,2 \mathrm{a}$ & $71,4 \mathrm{a}$ \\
150 & $100,1 \mathrm{a}$ & $642,7 \mathrm{a}$ & $236,9 \mathrm{a}$ & $979,7 \mathrm{a}$ & $72,0 \mathrm{a}$ \\
200 & $100,1 \mathrm{a}$ & $645,5 \mathrm{a}$ & $247,0 \mathrm{a}$ & $992,6 \mathrm{a}$ & $73,9 \mathrm{a}$ \\
\hline $\mathrm{n}$ & 5 & $657,2 \mathrm{a}$ & $241,1 \mathrm{a}$ & $998,4 \mathrm{a}$ & $73,4 \mathrm{a}$ \\
\hline C.V. $(\%)$ & 1,29 & 5 & 5 & 5 & 5 \\
\hline Valor $p$ & 1 & 3,27 & 6,82 & 2,24 & 2,37 \\
\hline
\end{tabular}

(1) Médias na coluna seguidas da mesma letra não diferem estatisticamente pelo teste de Tukey $P \leq 0,05$

4.2.3 Determinação do estádio de desenvolvimento dos micrósporos

Foi observada influência das concentrações de boro no desenvolvimento para a variável tétrade, sendo que o maior número de células nesse estádio foi observado nas plantas cultivadas nas concentrações a 50\%, 100, 150 e a 200\% de boro em relação à solução de Sarruge (1975), respectivamente. Os resultados das plantas que continha apenas $25 \%$ de boro em relação à solução de Sarruge (1975) foram similares aos das doses 100\% ou mais elevadas (Tabela 12).

Para o estádio mononucleado central, as plantas produzidas na concentração a $25 \%$ de boro apresentaram maior número de células do que na concentração de $200 \%$. Porém, ambas (25\% e 200\%) não diferiram estatisticamente das plantas produzidas nas concentrações 50\%, 100\% e 150\% de boro em relação à solução de Sarruge (1975) (Tabela 12).

Para os estádios mononucleado periférico e binucleado não foram observadas diferenças significativas entre as plantas cultivadas nas concentrações de boro presentes na solução de Sarruge (1975). Da mesma forma, não foi observado diferença significativa na produção de pólen "P” em função das doses de boro na solução de Sarruge (1975), aplicadas durante o cultivo das plantas doadoras das anteras (Tabela 12). 
Tabela 12 - Número médio de micrósporos nos diferentes estádios de desenvolvimento e índice de polens "P” em plantas de trigo da cultivar Genaro, cultivadas em cinco concentrações de boro em relação a solução de Sarruge (1975), até o ponto de coleta das espigas para a cultura de anteras

\begin{tabular}{clllll}
\hline $\begin{array}{l}\text { Boro na solução } \\
\text { de Sarruge } \\
(1975)(\%)\end{array}$ & \multicolumn{5}{l}{ Estádio de desenvolvimento dos micrósporos } \\
\cline { 2 - 6 } & Tétrade $^{(1)}$ & $\begin{array}{l}\text { Mononucleado } \\
\text { central }^{(1)}\end{array}$ & $\begin{array}{l}\text { Mononucleado } \\
\text { periférico }^{(1)}\end{array}$ & $\begin{array}{l}\text { Binucleado } \\
(1)\end{array}$ & $\begin{array}{l}\text { Pólen } \\
\text { "P" (1) }\end{array}$ \\
\hline 25 & $6,17 \mathrm{~b}$ & $10,22 \mathrm{a}$ & $9,19 \mathrm{a}$ & $8,36 \mathrm{a}$ & $8,56 \mathrm{a}$ \\
50 & $9,83 \mathrm{a}$ & $7,61 \mathrm{ab}$ & $5,86 \mathrm{a}$ & $7,33 \mathrm{a}$ & $8,25 \mathrm{a}$ \\
100 & $7,50 \mathrm{ab}$ & $8,42 \mathrm{ab}$ & $8,14 \mathrm{a}$ & $8,06 \mathrm{a}$ & $7,17 \mathrm{a}$ \\
150 & $7,17 \mathrm{ab}$ & $7,97 \mathrm{ab}$ & $8,61 \mathrm{a}$ & $8,31 \mathrm{a}$ & $8,47 \mathrm{a}$ \\
200 & $9,33 \mathrm{ab}$ & $5,78 \mathrm{~b}$ & $8,19 \mathrm{a}$ & $7,94 \mathrm{a}$ & $7,56 \mathrm{a}$ \\
\hline $\mathrm{n}$ & 18 & 18 & 18 & 18 & 18 \\
\hline C. V $(\%)$ & 43,71 & 55,96 & 52,99 & 22,98 & 54,06 \\
\hline Valor de $P$ & 0,0120 & 0,0682 & 0,1813 & 0,4702 & 0,8379 \\
\hline
\end{tabular}

(1) Médias na coluna seguidas da mesma letra não diferem pelo teste de Friedman $P \leq 0,05$

Houve influência significativa da posição da flor na espiga para o estádio mononucleado periférico, sendo que as anteras oriundas de flores da região mediana da espiga apresentaram o maior número de células nesse estádio, enquanto as flores das regiões apical e basal apresentaram as menores médias e não diferiram estatisticamente entre si. A maior média de micrósporos no estádio binucleado foi verificada nas anteras oriundas de flores da região mediana da espiga a qual não diferiu da região apical, que por sua vez, não diferiu da região basal (Tabela 13). Com relação à produção de polens “P”, as anteras das flores da posição apical das espigas apresentaram maior número desse tipo de células, seguida daquelas da posição basal a qual, não diferiu das oriundas da região mediana (Tabela 13).

Tabela 13 - Número médio de micrósporos em três estádios de desenvolvimento em três regiões da espiga de plantas de trigo da cultivar Genaro oriundas de cinco concentrações de boro na solução de Sarruge (1975) no ponto de coleta para a cultura de anteras

\begin{tabular}{|c|c|c|c|}
\hline \multirow{2}{*}{$\begin{array}{l}\text { Região da } \\
\text { espiga }\end{array}$} & \multicolumn{3}{|c|}{ Estádio de desenvolvimento dos micrósporos } \\
\hline & $\begin{array}{c}\text { Mononucleado } \\
\text { periférico }^{(1)}\end{array}$ & Binucleado $^{(1)}$ & Pólen $\mathrm{P}^{(1)}$ \\
\hline Apical & $7,12 \mathrm{~b}$ & $8,10 \mathrm{ab}$ & $9,67 \mathrm{a}$ \\
\hline Mediana & $9,90 \mathrm{a}$ & $8,57 \mathrm{a}$ & $6,32 b$ \\
\hline Basal & $6,98 b$ & $7,33 b$ & $8,02 \mathrm{ab}$ \\
\hline $\mathrm{n}$ & 30 & 30 & 30 \\
\hline C. V $(\%)$ & 35,5 & 46,1 & 60,5 \\
\hline Valor de $P$ & 0,0098 & 0,0030 & 0,0205 \\
\hline
\end{tabular}

(1) Médias seguidas da mesma letra não diferem pelo teste de Tukey $P \leq 0,05$ 
Com relação à influência das concentrações de boro na solução nutritiva descrita por Sarruge (1975) no desenvolvimento dos micrósporos nas diferentes faixas percorridas da folha bandeira menos um (FB-1) em função da distância total entre a folha bandeira e o último nó do colmo (FB/UN), houve influência significativa das concentrações do nutriente na solução no número de tétrades $(P=0,018)$ e o micrósporos no estádio mononucleado central $(P=0,045)$. Para as demais variáveis, não foram detectadas diferenças significativas entre as faixas. $\mathrm{Na}$ faixa intermediária (>40\% até $60 \%$ ), só foi verificada a influência das concentrações nos micrósporos no estádio mononucleado central $(P=0,018)$. Na terceira faixa $(>60 \%)$, houve influência das concentrações de boro somente sobre a frequência de polens "P" $(P=0,029)$.

\subsubsection{Produção de estruturas embriogênicas androgenéticas}

Não foi observada diferença estatística quanto à capacidade de formação de estruturas embriogênicas androgenéticas nas anteras oriundas das plantas cultivadas nas concentrações de boro na solução de Sarruge (1975), nos quatro meios de cultura testados (Figura 15).

\section{Estruturas embriogênicas}

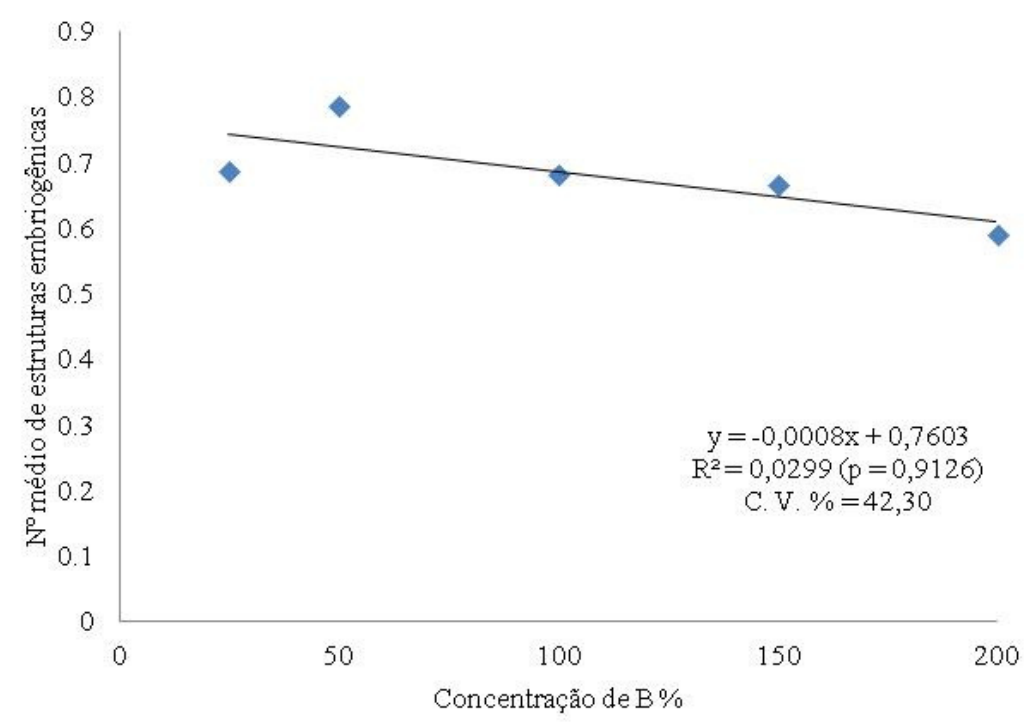

Figura 15 - Número médio de estruturas embriogênicas formadas a partir da cultura de anteras em quatro meios de cultura, em função das cinco concentrações de boro presentes na solução de Sarruge (1975) utilizadas na produção das plantas de trigo da cultivar Genaro doadoras de anteras

Para o número médio de anteras plaqueadas não houve diferença significativa entre as médias obtidas pelas plantas cultivadas nas concentrações de boro utilizadas na solução de 
Sarruge (1975) (Tabela 14). Da mesma forma não houve diferença significativa no número médio de anteras plaqueadas nos diferentes meios de cultura e no número médio de estruturas embriogênicas androgenéticas obtidas nos meios de cultura utilizados (Tabela 15).

Tabela 14 - Número médio de anteras plaqueadas oriundas das plantas de trigo, da cultivar Genaro, cultivadas em cinco concentrações de boro a partir da solução de Sarruge (1975)

\begin{tabular}{cc}
\hline Boro na solução de & $\mathrm{N}^{\mathbf{0}}$ anteras plaqueadas $^{(1)}$ \\
Sarruge $(1975)(\%)$ & $23,21 \mathrm{a}$ \\
\hline 25 & $22,81 \mathrm{a}$ \\
100 & $22,55 \mathrm{a}$ \\
150 & $22,81 \mathrm{a}$ \\
200 & $22,84 \mathrm{a}$ \\
\hline $\mathrm{n}$ & 24 \\
\hline C. V. (\%) & 7,10 \\
\hline Valor $P$ & 0,6284 \\
\hline${ }^{(1)}$ Médias na coluna seguidas da mesma letra não diferem pelo teste de Tukey $P \leq 0,05$
\end{tabular}

Tabela 15 - Número médio de estruturas embriogênicas androgenéticas formadas nos meios de cultura utilizados para o cultivo das anteras oriundas das plantas de trigo, da cultivar Genaro, produzidas em cinco concentrações de nitrogênio a partir da solução de Sarruge (1975)

\begin{tabular}{cc}
\hline Meio & $\mathrm{N}^{\mathbf{o}}$ estruturas embriogênicas \\
& $(1)$ \\
$\mathrm{I}^{(2)}$ & $0,6965 \mathrm{a}$ \\
$\mathrm{II}^{(3)}$ & $0,8271 \mathrm{a}$ \\
$\mathrm{III}^{(4}$ & $0,8433 \mathrm{a}$ \\
$\mathrm{IV}^{(5)}$ & $0,6573 \mathrm{a}$ \\
\hline $\mathrm{n}$ & 20 \\
\hline C. V $(\%)$ & 45,9 \\
\hline Valor de $P$ & 0,2342 \\
\hline
\end{tabular}

${ }^{(1)}$ Médias na coluna seguidas da mesma letra não diferem pelo teste de Tukey $P \leq 0,05$

(2) Batata II

(3) Batata II s/ 2,4-D + $2 \mathrm{mg} \mathrm{L}^{-1}$ de ácido benzoico

(4) Batata II s/ 2,4-D + $4 \mathrm{mg} \mathrm{L}^{-1}$ de ácido benzoico

${ }^{(5)}$ Batata II s/ 2,4-D + $1 \mathrm{mg} \mathrm{L}^{-1} \mathrm{ANA}+1 \mathrm{mg} \mathrm{L}^{-1}$ de ácido benzoico

A análise de correlação entre as estruturas embriogênicas produzidas com os componentes do rendimento não apresentou resultados significativos para as plantas cultivadas nas concentrações de boro em relação à solução de Sarruge (1975). 


\section{DISCUSSÃO}

5.1 Os componentes do rendimento

Os componentes do rendimento são parâmetros importantes para determinar a produtividade das plantas de lavoura e por isso têm sido muito estudados em escala mundial. Por outro lado, a relação dos componentes do rendimento com a resposta androgenética em trigo carece de informações, uma vez que a grande maioria dos trabalhos realizados na área de produção de plantas haploides concentra-se em avaliar as condições de cultivo in vitro como, por exemplo, pré-tratamentos das espigas e/ou anteras, composição do meio de cultivo, condições de incubação etc., negligenciando a origem das anteras e/ou micrósporos utilizados (FERRANTE; SAVIN; SLAFER, 2013).

No que diz respeito à produção de plantas haploides, a influência da nutrição difere dos estudos normais de efeito da adubação no trigo por, no mínimo, dois pontos básicos: 1) o estádio de desenvolvimento em que as plantas são colhidas é ainda no emborrachamento (9 10 da escala de FEEKES-LARGE, 1954 ou 44 da escala proposta por ZADOKS; CHANG; KONZAK, 1974), fase anterior à antese e, portanto, muito longe da maturação fisiológica e 2) o produto de interesse são as estruturas embriogênicas e, posteriormente, as plantas verdes haploides regeneradas destas estruturas e não o grão.

Nesse sentido, Wiesler (2012) afirmou que para as plantas, de um modo geral, a nutrição pode influenciar no acúmulo de características qualitativas e que a alta qualidade da planta como um todo está relacionada com alta disponibilidade de nutrientes. Além disso, a alta concentração de nitrogênio pode modificar o metabolismo das plantas, bem como diminuir a concentração de alguns carboidratos de reserva, amido e polifrutosanos em gramíneas de modo geral, aumentar os níveis de alguns açúcares específicos como os $\beta$-glicanos e de proteínas de reserva em cereais como o trigo e a aveia. Gebbing e Schnyder (1997) estudaram a partição de carbono acumulado no período pré-antese para a síntese de proteínas e para o enchimento de grãos e observaram que a translocação do carbono dos tecidos para o grão é maior nas plantas submetidas a menores concentrações de nitrogênio. Porém, não há referências da influência da translocação de substâncias de reserva na qualidade dos micrósporos.

A influência das concentrações de nitrogênio nas variáveis que constituem os componentes do rendimento foi suficiente para promover o crescimento e o desenvolvimento diferenciado nas plantas doadoras de anteras. Nesse sentido, Wiethölter (2011) ressaltou que o 
trigo utiliza o nitrogênio durante a fase vegetativa para sustentar o seu crescimento e acumular fotoassimilados nos tecidos para, após a antese e fecundação das flores, serem translocados dos tecidos de reserva para os grãos. Martre et al. (2006) ressaltaram que a produção da parte aérea, bem como o teor de proteínas no grão do trigo, está ligada a disponibilidade de nitrogênio durante o ciclo da cultura.

Por outro lado, plantas oriundas das concentrações de boro não apresentaram o mesmo efeito no crescimento e desenvolvimento dos componentes do rendimento, não sendo constatadas diferenças significativas para as variáveis estudadas.

O número de colmos por planta, o diâmetro e o comprimento do colmo principal foram influenciados pela concentração de nitrogênio na solução de cultivo das plantas doadoras das anteras, uma vez que as concentrações acima de 100\% de nitrogênio, apresentaram os maiores valores médios para as variáveis. Esses resultados são importantes, pois na androgênese em trigo é utilizada como doadora, de anteras e/ou micrósporos, apenas a espiga do colmo principal da planta, uma vez que as anteras dessa espiga tendem a ser mais responsivas à indução de estruturas embriogênicas androgenéticas. Nesse sentido, Henry e Buyser (1990) relataram que a resposta androgenética em trigo pode ser diferenciada dentro da mesma planta entre as espigas, as flores de uma mesma espigueta e até mesmo entre as anteras de uma mesma flor.

O efeito diferenciado também foi observado na concentração de clorofila na folha bandeira, bem como no comprimento, largura e área total da mesma nas plantas cultivadas sob concentrações de nitrogênio na solução nutritiva de Sarruge (1975). Esses resultados concordam com os obtidos por Fois, Motzo e Giunta (2009), os quais observaram aumento da área foliar e conteúdo de nitrogênio na folha bandeira de trigo no período da antese em plantas com maior suplementação desse nutriente. $O$ interesse na influência das concentrações de nitrogênio no desenvolvimento da folha bandeira se deve ao fato de que esta é responsável por grande parte da fotossíntese líquida das plantas de trigo nessa fase do desenvolvimento (KING; WARDTLAW; EVANS, 1967). Consequentemente, ela torna-se responsável pela síntese de fotoassimilados para os tecidos da planta doadora das anteras, bem como para os micrósporos até o estádio de coleta das espigas. As concentrações de boro, no entanto, provocaram diferenças significativas no teor de clorofila, mas não influenciaram nas variáveis referentes à folha bandeira. Esses resultados concordam com os de Huang et al. (2000) que relataram, em experimento com supressão de boro, não ocorrer sintomas visíveis nas folhas mesmo após 25 dias de tratamento.

Para as variáveis massa fresca e massa seca da parte aérea as concentrações de nitrogênio promoveram o desenvolvimento diferenciado nas plantas e, os resultados concordam 
com o efeito descrito por Garabet, Wood e Rayan (1998), os quais verificaram também que o nitrogênio promove incremento significativo na massa da parte aérea seca do trigo e influencia na capacidade de utilização eficiente da água pelas plantas. Da mesma forma, Rissini (2011) registrou aumento significativo da massa seca da parte aérea de acordo com o aumento da adubação nitrogenada no trigo cultivado no campo.

O efeito significativo das concentrações de nitrogênio da solução utilizada durante o cultivo das plantas doadoras de anteras na distância entre a folha bandeira (FB) e o último nó (UN) pode interferir diretamente na produção de estruturas androgênicas e/ou plantas haploides oriundas da cultura de anteras e/ou micrósporos isolados, uma vez que essa distância é constituinte do indicador morfológico que, geralmente, é utilizado para estimar o ponto de coleta das espigas doadoras de anteras e/ou micrósporos (WHEATLEY; MARSOLAIS; KASHA, 1986).

Com relação à massa fresca e massa seca da parte aérea, as maiores concentrações de nitrogênio promoveram aumento significativo das variáveis tanto nas plantas avaliadas no momento da coleta das espigas quanto nas plantas mantidas até o final do ciclo. Esses resultados concordam com os de Bancal (2009), que observou correlação positiva entre o aumento no comprimento dos colmos com o aumento na massa seca das plantas. Também Sinclair e Jamieson (2006) relataram aumento no número de grãos produzidos em plantas de trigo cultivadas com maiores teores de nitrogênio.

Com relação ao boro, não houve diferença significativa entre as concentrações para as variáveis. Esse resultado difere dos obtidos por Wongmo, Jamjod e Rerkasem (2004) que, ao testar a deficiência de boro em cevada e trigo, observaram que houve significativa redução do número de grãos por espiga quando cultivados nas menores doses de boro. Os resultados indicam que mesmo as menores concentrações utilizadas nesse experimento foram suficientes para atender a demanda do trigo e, consequentemente, as plantas não apresentaram os sintomas de carência. Conforme Malavolta (2006), a concentração ideal de boro na parte aérea das plantas de trigo é de $20 \mathrm{mg} \cdot \mathrm{kg}^{-1}$ de tecido. De acordo com o observado na parte aérea das plantas utilizadas no experimento (Tabela 9) a partir da solução com concentração a 100\% de boro em relação à solução descrita por Sarruge (1975), a concentração de boro nos tecidos das plantas é superior ao considerado normal para a cultura do trigo (MALAVOLTA, 2006). Essa observação pode explicar porque as concentrações de boro não provocaram diferenças significativas na maioria das variáveis dos componentes do rendimento.

Com relação ao acúmulo de graus-dias (GD) foi observado que, embora o experimento tenha sido conduzido em ambiente totalmente controlado, as plantas apresentaram diferenças 
sutis entre as médias de graus-dias acumulados em função da concentração de nitrogênio na solução nutritiva utilizada no seu cultivo, porém, essas diferenças não foram significativas estatisticamente.

No que diz respeito aos experimentos com boro não houve oscilações significativas na média de acúmulo de graus-dias. As médias obtidas nos estádios de desenvolvimento não foram estatisticamente diferentes entre si. Esses resultados diferem dos apresentados por Kirby et al. (1999), os quais observaram que o total de graus-dias acumulado no período de emergência, em variedades de trigo semeadas no campo, pode sofrer a ação de fatores ambientais como data, local e estação do ano em que foi feita a semeadura. Da mesma forma, afirmaram que o estádio de espigueta terminal sofre a ação do fotoperíodo a que as plantas foram expostas e que o acúmulo total de graus-dia é influenciado pelas fases subsequentes.

As doses de nitrogênio podem ainda acelerar ou retardar o desenvolvimento do pólen e, como consequência, fazer com que o ponto morfológico de coleta não corresponda ao ponto citológico em que os micrósporos são capazes de reverter à rota gametofítica em esporofítica (mononucleado central e periférico). Assim, dependendo da dose da adubação nitrogenada utilizada nas plantas doadoras de anteras, pode-se cometer o erro de isolar os micrósporos que ainda não atingiram o estádio adequado para cultura ou, por outro lado, que já passaram desse estádio. Nesse sentido, Bohanec (2009) ressaltou que a determinação do ponto correto para o isolamento dos micrósporos é um dos fatores mais importantes para a obtenção de sucesso na produção de estruturas embriogênicas e/ou plantas haploides via androgênese. A diferença média em dias de cultivo entre a menor e a maior concentração de nitrogênio na solução atingiu 3,3 dias. Ou seja, nas condições que o experimento foi realizado, a utilização de concentrações de nitrogênio mostrou-se capaz de fazer com que as anteras dos tratamentos com maior concentração desse nutriente fossem plaqueadas três dias antes do estádio correto. Por outro lado, as anteras das plantas cultivadas nas menores concentrações, seriam plaqueadas três dias depois do estádio correto. Esses resultados são semelhantes aos de Tsay (1981), que observou redução do período da semeadura até o florescimento em plantas de fumo cultivadas sob-baixas concentrações de nitrogênio. Por outro lado, Ferrante, Savin e Slafer (2013) não verificaram alteração no período de iniciação floral em T. durum L. cultivado sob duas concentrações de nitrogênio. Considerando o tempo para ocorrer a microsprorogênese e a microgametogênese em trigo, pode-se dizer que essa oscilação no ponto de coleta pode ser responsável pela falta de sucesso em muitos experimentos de androgênese nessa cultura.

A falta de significância estatística no que diz respeito ao comprimento das espigas, tanto para os experimentos com concentrações de nitrogênio quanto para os experimentos com 
concentrações de boro, pode ser justificada pela metodologia aplicada para a determinação dessa variável, a qual considerou a distância entre o local da inserção do primeiro par de espiguetas da base até a ponta da última espigueta no ápice da espiga. Isto significa que não foi considerada a viabilidade ou não das flores presentes nessas espiguetas. Como o comprimento da ráquis é um fator genético, o tamanho total da espiga não variou de acordo com as doses de nitrogênio e de boro utilizadas dentro da mesma cultivar.

Foi constatado que as concentrações de nitrogênio interferiram no número de flores que apresentavam anteras viáveis para o plaqueamento, uma vez que houve diferença significativa na análise do número de anteras plaqueadas por dose de nitrogênio em cada bloco $(P=0,0001)$. Essas diferenças significativas refletem a viabilidade das anteras nas espigas de acordo com a concentração de nutriente que a planta doadora recebeu e consequentemente, permite a estimativa da viabilidade das flores na espiga. Outro indicativo desta viabilidade foi o número e a massa de grãos produzidos pelas plantas cultivadas nas concentrações de nitrogênio cultivadas até o final do ciclo. Esses resultados concordam com os de Engels, Kirkby e White (2012), os quais afirmaram que fertilizantes nitrogenados aumentaram o número de flores férteis e reduziram a degeneração de flores durante o período de elongação do colmo em T. durum e cevada. E com os obtidos por Arisnabarreta; Miralles (2010), os quais observaram que durante a fase inicial do perfilhamento (quatro folhas), a disponibilidade de nitrogênio define o número de espiguetas por espiga e, na fase final (sete folhas), a concentração de nitrogênio define o número de perfilhos que formarão espigas férteis, ou seja, o número de espigas por unidade de área.

Para o boro não houve diferença significativa no número de anteras plaqueadas entre as concentrações. Isso indica que as espigas não diferiram no número de flores com anteras viáveis, mesmo na menor concentração (25\% de boro em relação à solução de Sarruge, 1975).

\subsection{O desenvolvimento dos micrósporos}

O desenvolvimento das flores e, consequentemente, do pólen dentro da espiga do trigo ocorre da região central para as extremidades primeiramente a apical e por último a basal. De acordo com González, Miralles e Slafer (2011), esse comportamento se deve à partição dos fotoassimilados no trigo, os quais são repassados primeiramente, para as espiguetas centrais e do ápice e, posteriormente, para as espiguetas da base da espiga. 
Ao longo dos experimentos, pode-se observar visual e citologicamente que o desenvolvimento das espigas foi diferente de acordo com a dose de nitrogênio que a planta doadora recebeu durante o seu cultivo. Embora a semeadura, a emergência e as condições ambientais das plantas não tenha apresentado variação, observaram-se diferenças no desenvolvimento das espigas e, consequentemente, no grau de desenvolvimento dos micrósporos.

A concentração de nitrogênio na solução de cultivo da planta doadora apresentou diferença significativa na distância total entre a FB e o UN (Figura 7c) e, como consequência, a utilização do padrão morfológico para a coleta das espigas ficou comprometido, uma vez que dependendo da concentração de nitrogênio utilizado, o desenvolvimento da planta e dos micrósporos foi diferente.

A análise do desenvolvimento dos micrósporos mostrou que o efeito das doses de nitrogênio não alterou o curso de desenvolvimento dos mesmos dentro das espigas, mas sim, o desenvolvimento da espiga dentro da planta. Isso ficou evidenciado pela análise do estádio de desenvolvimento dos micrósporos nas faixas de deslocamento da folha bandeira menos um ao longo do espaço compreendido entre a folha bandeira e o último nó, a qual demonstrou que a influência nutricional ocorre justamente durante o deslocamento da FB-1 até o primeiro terço independente da solução em que a planta tenha sido cultivada, coincidindo com o espaço utilizado como o padrão morfológico para coleta das espigas visando à cultura anteras em trigo.

Os resultados para as variáveis tétrade e mononucleado central comprovam que houve o processo normal de maturação dos grãos de pólen dentro da espiga. Uma vez que ela ocorreu da região central para as extremidades e demonstrou que o desenvolvimento do pólen na espiga não é afetado pela nutrição. Essa influência somente é observada quando se considera o estádio de desenvolvimento do pólen como um todo, independentemente da posição dentro da espiga.

Da mesma forma que no experimento com nitrogênio, a influência das concentrações de boro presentes na solução nutritiva de Sarruge (1975) utilizada nas plantas doadoras de anteras se concentra no primeiro terço de deslocamento da FB-1. Esses resultados concordam com os de Huang et al. (2000) que observaram que a ação da deficiência de boro durante microsporogênese e, consequentemente, na fertilidade do pólen em trigo, ocorre ao redor de sete dias após emergência total da folha bandeira. De acordo com o observado no experimento, esse período de tempo coincide com a migração da folha bandeira menos um até o primeiro terço da distância total entre a folha bandeira e o nó de inserção do pedúnculo da espiga.

Por outro lado, a falta de esterilidade na concentração a $25 \%$ de boro $(0,000715 \mathrm{~mol}$ $\mathrm{L}^{-1}$ ) em relação à solução de Sarruge (1975) pode ser atribuída ao fato de ser uma dose muito 
elevada para provocar esse efeito. A concentração de boro na parte aérea das plantas nesse experimento foi de $12,1 \mathrm{mg} \mathrm{kg}^{-1}$ de boro na menor concentração utilizada (Tabela 9). Nesse sentido, Huang et al. (2000) salientaram que, para o trigo, a concentração de $8 \mathrm{mg} \mathrm{kg}^{-1}$ de boro nas anteras e 5 - $6 \mathrm{mg} \mathrm{kg}^{-1}$ de boro nos carpelos são suficientes para apresentar fertilidade normal. Além disso, a capacidade de tolerar a deficiência de boro em trigo é uma característica genética que pode variar de um genótipo para outro, fazendo com que as doses mínimas exigidas mudem de acordo com a cultivar estudada.

\subsection{A formação de estruturas embriogênicas androgenéticas}

A formação de estruturas embriogênicas foi altamente influenciada pela concentração de nitrogênio na qual a planta doadora de anteras foi cultivada. Nas condições em que esse experimento foi realizado, o número de estruturas embriogênicas aumentou de modo linear conforme ocorreu o incremento das doses aplicadas. De acordo com a análise de regressão, a influência das concentrações de nitrogênio na formação de estruturas embriogênicas chegou a 39,78\%. Esses resultados concordam com os de Tsay (1981), que afirmou que as condições nutricionais das plantas doadoras de anteras e/ou micrósporos são muito importantes para se obter sucesso na produção de plantas haploides e também com os resultados de Magalhães Jr. et al. (1993), na indução de estruturas embriogênicas em arroz visando à produção de plantas haploides. Além disso, essas informações são extremamente importantes, pois indicam que as condições nutricionais das plantas doadoras de anteras podem representar mais de um terço da garantia de sucesso na produção de plantas haploides em trigo e que existe forte relação entre as condições nutricionais da planta doadora na indução da habilidade de reversão da rota gametofítica para esporofítica nessa espécie. Nesse sentido, Eudes e Chugh (2009), ressaltaram que na cultura de anteras de triticale a qualidade das plantas doadoras representa $50 \%$ do sucesso na obtenção de plantas haploides. Para o trigo da cultivar Genaro, os $60 \%$ restantes ficariam sob a responsabilidade do genótipo e dos demais fatores ambientais (intensidade luminosa, meio de cultura, temperatura, etc.). Esses resultados diferem dos apresentados por Tsay (1981), que ao avaliar o efeito de concentrações de nitrogênio na produção de plantas haploides em fumo, observou que as cinco doses avaliadas não diferiram entre si no que diz respeito à indução de estruturas embriogênicas, mas sim na regeneração de plantas verdes através dessas estruturas. Isso indica que o efeito das doses de nitrogênio nas plantas doadoras de anteras pode variar de acordo com a espécie estudada. 
Os resultados positivos na formação de estruturas androgenéticas obtidos na cultura de anteras nos meios I e IV podem ser explicados pela presença de auxinas 2,4-D e ácido naftaleno acético (ANA), respectivamente. Nesse sentido, Gosal et al. (1997) resaltaram que na cultura de anteras de arroz, a presença das auxinas 2,4-D e ANA, juntamente com a kinetina, aumentou a frequência de indução de calos. Nos meios II e III nos quais a auxina (2,4-D) foi substituída apenas por ácido benzoico, os resultados mostraram que este composto não foi eficaz na substituição da auxina no meio de indução para a cultura de anteras de trigo. Esses resultados diferem dos reportados por Henry e Buyser (1990), os quais afirmaram que o ácido benzoico estaria envolvido na capacidade de obtenção de embriões de melhor qualidade na cultura de anteras de trigo.

Embora o número de anteras plaqueadas por concentração de nitrogênio tenha apresentado variação significativa, o número de anteras plaqueadas nos quatro meios testados não mostrou diferença significativa $(P=0,5660)$. Isso é importante, pois mostra que os resultados para as estruturas embriogênicas nos meios de cultura não foram influenciados pelo número de anteras plaqueadas e sim pela composição do meio.

Com relação ao boro, as concentrações avaliadas não foram capazes de influenciar na formação de estruturas androgenéticas. Provavelmente, isso se deve ao fato da concentração utilizada estar acima do nível crítico para a cultura do trigo.

A análise de correlação das estruturas embriogênicas formadas com os componentes do rendimento das plantas cultivadas nas concentrações de nitrogênio confirmou a importância do estado nutricional da planta doadora na resposta androgenética, uma vez que os componentes correlacionados foram os envolvidos com o acúmulo de reservas e síntese de fotoassimilados para as plantas. Esses resultados concordam com os de Dodig et al. (2008), os quais observaram correlação significativa entre os componentes do rendimento e a capacidade de calos embriogênicos e a regeneração tecidos somáticos de plantas de trigo. Por outro lado, as plantas submetidas às concentrações de boro em relação à solução descrita por Sarruge (1975), não apresentaram correlação significativa entre as variáveis. 


\section{CONCLUSÕES}

As concentrações de nitrogênio utilizadas nos experimentos provocaram modificação positivas na resposta das variáveis dos componentes do rendimento: comprimento e diâmetro do colmo principal; comprimento, largura e área da folha bandeira; massa fresca e massa seca da parte aérea; teor de clorofila da folha bandeira e a distância entre a folha bandeira e o último nó do colmo.

O aumento na concentração de nitrogênio no cultivo das plantas doadoras de anteras influenciou linear e positivamente na capacidade de indução de formação estruturas embriogênicas androgenéticas in vitro.

As concentrações de nitrogênio alteraram a dinâmica de desenvolvimento dos micrósporos promovendo diferenças nos estádio de desenvolvimento dos mesmos e, consequentemente, no padrão morfológico para a coleta das espigas doadoras das anteras visando à produção de plantas haploides via androgênese.

As concentrações de boro utilizadas no experimento não foram suficientes para causar influência significativa com relação aos componentes do rendimento, no desenvolvimento dos micrósporos e, principalmente, na formação de estruturas embriogênicas androgenéticas. 


\section{REFERÊNCIAS}

AIONESEI, T.; TOURAEV, A.; HEBERLE-BORS, E. Pathways to microspore embryogenesis. In: NAGATA, T.; WIDHOLM, J. M. Haploid in crop improvement II. Berlin: Spring-Verlag, 2005. chap. I. 2, p. 11-34. (Biotechnology in Agriculture and Forestry, 56).

ARIAS, G. Trigo na América do Sul. In: CUNHA, G.R. (Org.). Trigo, 500 anos no Brasil. Passo Fundo: Embrapa Trigo, 1999. p. 59-62.

ARISNABARRETA, S.; MIRALLES, D.J. Nitrogen and radiation effects during the active spike-growth phase on floret development and biomass partitioning in 2- and 6-rowed barley isolines. Crop \& Pasture Science, Victoria, v. 61, p. 578-587, 2010.

BAENZIGER, P.S. Reflections on doubled haploids in plant breeding. In: JAIN, S.M.; SOPORY, S.K.; VEILLEUX, R.E. In vitro haploid production in higher plants:

fundamentals aspects and methods. Amsterdam: Kluwer Academic, 1996. v. 1, p. 35-48.

BAJAJ, Y.P.S. In vitro production of haploids and their use in cell genetics and plant breeding. In: Haploids in crop improvement I. Berlin: Spring-Verlag, 1990. p. 344. (Biotechnology in Agriculture and Forestry, 12).

BANCAL, P. Early development and enlargement of wheat floret primordial suggest a role of partitioning within spike to grain set. Field Crop Research, Amsterdam, v. 110, p. 44-53, 2009.

BARNABÁS, B.; SZAK'ACS, E.; BEDÖ, Z. In vitro androgenesis of wheat: from fundamentals to practical application. Euphytica, Wageningen, v. 119, p. 211-216, 2001.

BASU, S.K.; DATTA, M.; SHARMA, M.; KUMAR, A. Haploid production technology in wheat and some selected higher plants. Australian Journal of Crop Science, Melbourne, v. 5, p. 1087-1093, 2011.

BATYGINA, T.B. Embryology of flowering plants: terminology and concepts. Enfield: Science Publ., 2002. 421 p. (Generative Organ of Flower, 1).

BOHANEC, B. Double haploids via Gymnogenesis. In: TOURAEV, A.; FORSTER, B.P.; JAIN, S.M. (Ed.). Advances in haploid production in higher plants. New York: Springer, 2009. chap. 2, p. 35-46.

BOX, G.E.P.; COX. D.R. An analysis of transformations. Journal of the Royal Statistical Society. Series B., London, v. 26, p. 211-252, 1964.

BROADLEY, M.; BROWN, P.; CAKMAK, I.; RENGEL, Z.; ZHAO, F. Function of nutrients: micronutrients. In: MARSCHNER'S, P. Mineral nutrition of higher plants. $3^{\text {rd }}$ ed. Washington: Academic Press, 2012. chap. 7, p. 191-248.

BUCHANAN, B.B.; GRUISSEM, W.; JONES, R.L. Biochemistry and molecular biology of plants. Rockville: American Society of Plant Physiologists, 2000. 1367 p. 
CAETANO, V.R.; MORAES-FERNANDES, M.I.B. Interdisciplinariedade no CNPT-

EMBRAPA: estudos que culminaram com o lançamento, com métodos biotecnológicos, do trigo BR 43. In: ENCONTRO DE GENETICISTAS DO RIO GRANDE DO SUL, 8., 1992, São Leopoldo. Anais... São Leopoldo: SBG, 1992 p. 15-19.

CAKMAK, I.; ENGELS, C. Role of mineral nutrients in photosynthesis and yield formation. In: RENGEL, Z. (Ed.). Mineral nutrition of crops. New York: Food Products Press, 1999. chap. 6, p. 141-168.

COPSTEIN, R. Triticultura gaúcha no Brasil colonial. In: CUNHA, G.R. (Org.). Trigo, 500 anos no Brasil. Passo Fundo: Embrapa Trigo, 1999. p. 45-50.

CORDEWENER, J.H.G.; CUSTERS, J.B.M.; DONS, H.J M.; VAN LOOKEREN CAMPAGNE, M.M. Molecular and biochemical events during the induction of microspore embryogenesis. In: MOHAN JAIN, S.; SOPORY, S.K.; VEILLEUX, R.E. In vitro haploid production in higher plants. London: Kluwer Academic, 1996. p. 111-124. (Current Plant Science and Biotechnology in Agriculture, 1).

DANIEL-VEDELE, F.; CHAILLOU, S. Nitrogen. In: BROADLEY, M.R.; WHITE, P.J. Plant mineral genomics. Oxford: Blackwell, 2005. chap. 1, p. 1-25.

DATTA, S.K. Androgenics haploids: factor controlling development and its implications in crop improvement. Current Science, Bangalore, v. 89, n. 11, p.1870-1878, Dec. 2005.

DE CESARO, T. Microesporogênese e capacidade androgenética de genótipos de Avena sativa L. e Avena sterilis L. 2002. 89 p. Dissertação (Mestrado em Produção Vegetal) Universidade de Passo Fundo, Passo Fundo, 2002.

DE MORI, C.; IGNAZAK, J.C. Aspectos econômicos do complexo agroindustrial do trigo. In: PIRES, J.; VARGAS, L.; CUNHA, G.R. (Ed.). Trigo no Brasil: bases da produção competitiva e sustentável. Passo Fundo: Embrapa Trigo, 2011. cap. 3, p. 41-76.

DEVAUX, P.; PICKERING, R. Haploids in the improvement of Poaceae. In: PALMER, C.E.; KELLER, W.A.; KASHA, K.J. Haploids in crop improvement. Berlin: SpringerVerlag, 2005. p. 215-242. (Biotechnology in Agriculture and Forestry, 56).

DICKINSON, H.G. Microspore derived embryogenesis. In: CRESTI, M.; TIEZZI, A. Sexual plant reproduction. Berlin: Spring-Verlag, 1992. p. 1-15.

DODIG, D.; ZORIĆ, M.; MITIĆ, N.; NIKOLIĆ, R.; SURLAN-MOMIROVIĆ, G. Tissue culture and agronomic relationship in wheat. Plant Cell Tissue Organ Culture. Dordrecht, v. 95, p. 107-114, 2008.

EKIZ, H.; KONZAK, C.F. Effects of light regimes on anther culture response in bread wheat. Plant Cell, Tissue and Organ Culture, Amsterdam, v. 50, p. 7-12, 1997.

ENGELS, C.; KIRKBY, E.; WHITE, P. Mineral nutrition, yield and source-sink relationships. In: MARSCHNER'S, P. Mineral nutrition of higher plants. $3^{\text {rd }}$ ed. Washington: Academic Press, 2012. chap. 5, p. 85-133.

EPSTEIN, E.; BLOOM, A. Nutrição de plantas: princípios e perspectivas. Trad. de M.E.T. Nunes. Londrina: Editora Planta. 2006. 403 p. 
EUDES, F.; CHUGH, A. An overview of triticale doubled haploids. In: TOURAEV, A.; FORSTER, B.P.; JAIN, S.M. (Ed.). Advances in haploid production in higher plants. New York: Springer. 2009. chap. 6, p. 87-96.

FERRANTE, A.; SAVIN, R.; SLAFER, G. A. Floret development of durum wheat in response to nitrogen availability. Journal of Experimental Botany. Oxford, v. 61, p. 4351-4359, 2010.

FERRIE, A.M.R.; PALMER, C.E.; KELLER, W.A. Haploid embryogenesis. In: THORPE, T.A. In vitro embriogenesis in plants. Amsterdam: Kluwer Academic, 1995. v. 20, p. 309344.

FLOSS, E.L. Fisiologia das plantas cultivadas: o estudo do que está por trás do que não se vê. Passo Fundo: UPF, 2004. 528 p.

FOIS, S.; MOTZO, R.; GIUNTA, F. The effects of nitrogenous fertilizer application on leaf traits in durum wheat in relation to grain yield and development. Field Crop Research.

Amsterdam, v. 110, p. 69-75, 2009.

FORNASIERI FILHO, D. Manual da cultura do trigo. Jaboticabal: FUNEP, 2008. 338 p.

GARABET, S.; WOOD, M.; RYAN, J. Nitrogen and water-use and nitrogen accumulation. Field Crops Research, Amsterdam, v. 57, p. 309-318, 1998.

GEBBING, T.; SCHNYDER, H. Pre-anthesis reserve utilization for protein and carbohydrate synthesis in grains of wheat. Plant Physiology, Rockville, v. 121, p. 871-878, 1999.

GONZÁLEZ, F.G.; MIRALLES, D.J.; SLAFER, G.A. Wheat floret survival as related to preanthesis spike growth. Journal of Experimental Botany, Oxford, v. 62, p. 4889-4901, 2011.

GOSAL, S.S.; SINDHU, A.S.; SANDHU, J.S.; SANDHU-GILL, R.; SINGH, B.; KHEHRA, G.S.; SIDHU, G.S.; DHALIWAL, H.S. Haploid in rice. In: JAIN, S.M.; SOPORY, S.K.; VEILLEUX, R.E. (Ed.) In vitro haploid production in higher plants: cereals. New York: Kluwer Academic, 1997. v. 4, chap. 1, p. 1-35.

GRANDO, M.F.; MORAES-FERNANDES, M.I.B. Two point deterministic model for acquisition of in vitro pollen grain androgenetic capacity based on wheat studies. Brazilian Journal of Genetics, Ribeirão Preto, v. 20, p. 467-476, 1987.

Capacidade androgenética e sua relação com o dimorfismo do pólen em linhagens duplo-haploides de trigo (Triticum aestivum L.) obtidas por cultura de anteras. 1989. 186 p. Dissertação (Mestrado em Genética) - Universidade Federal do Rio Grande do Sul, Porto Alegre, 1989.

GUHA, S.; MAHESHWARI, S.C. In vitro production of embryos from anthers of Datura. Nature, London, v. 204, p. 497, 1964.

GUSTAFSON, V.D.; BAENZINGER, P.S.; WRIGHT, M.S.; STROUP, W.W.; YEN, Y.; Plant cell, Isolated wheat microspore culture. Tissue and Organ Culture. Dordrecht, v. 42, p. 207-213, 1995. 
HAWKESFORD, M.; HORST, W.; KICKEY, T.; LAMBERS, H.; SCHJOERRING, J.; SKRUMSAGER, M.; WHITE, P. Functions of macronutrients. In: MARSCHNER'S, P. Mineral nutrition of higher plants. $3^{\text {rd }}$ ed. Washington: Academic Press, 2012. chap. 6, p. $135-189$.

HEBERLE-BORS, E.; ODENBACH, W. In vitro pollen embryogenesis and citoplasmatic male sterility in Triticum aestivum L. Zeitschrift fur Pflanzenzuchtung. Berlin, v. 95, p. 1422,1985 .

HEBERLE-BORS; E.; REINERT, J. Androgenesis in isolated pollen cultures of Nicotiana tabacum: Upon pollen development. Protoplasma. Berlin, v. 99, p. 237-245, 1979.

HENRY, Y.; BUYER, J. de. Wheat anther culture: agronomic performance of doubled haploid lines and the release of a new variety "Florin". In: BAJAJ, Y.P.S. Biotechnology in agriculture and forestry: wheat. Berlin: Spring Verlag, 1990. v. 13, p.285-352.

HU, H. In vitro induced haploids in wheat. In: JAIN, S.M.; SOPORY, S.K.; VEILLEUX, R.E. In vitro haploid production in higher plants: cereals. Amsterdam: Kluwer Academic, 1997. v. 4, p. 73-97.

HU, T.; KASHA, K.J. Improvement of isolated microspore culture of wheat (Triticum aestivum L.) through ovary co-culture. Plant Cell Reports, Berlin, v. 16, p. 520-525, 1997.

A cytological study of pretreatments used to improve isolated microspore of wheat cultures of wheat (Triticum aestivum L.) cv. Chris. Genome, Ottawa, v. 42, p. 432-441, 1999.

HU, T.C.; ZIAUDDIN, A.; SIMION, E.; KASHA, K.J.; Isolated microspore culture of wheat (Triticum aestivum L.) in a defined media: effects of pretreatment, isolation methods, and hormones. In Vitro Cellular and Developmental Biology, Gaithersburg, v. 31, p. 79-83, 1995.

HUANG, B. Wheat anther culture: effect of temperature. In: BAJAJ, Y.P.S. Biotechnology in agriculture and forestry: wheat. Berlin: Spring-Verlag, 1990. v. 13, p. 403-424.

HUANG, L.; PANT, J.; DELL, B.; BELL, R. Effects of boron deficiency on anther development and floret fertility in wheat (Triticum aestivum L. 'Wilgoyne'). Annals of Botany. London, v. 85, p. 493-500, 2000.

INDRIATO, A.; HEBERLE-BORS, E.; TOURAEV, A. Assessment of various stresses and carbohydrates for their effect on the induction of embryogenesis in isolated wheat microspores. Plant Science, Limerick, v. 143, p. 71-79, 1999.

\section{INSTITUTO BRASILEIRO DE GEOGRAFIA E ESTATÍSTICA. Estatística da produção} agrícola. 2014. Disponível em:

<ftp://ftp.ibge.gov.br/Producao_Agricola/Levantamento_Sistematico_da_Producao_Agricola _[mensal]/Fasciculo/lspa_201403.pdf>. Acesso em: 23 abr. 2014.

IWANAMI, Y.; SASAKUMA, T.; YAMADA, Y. Pollen: illustrations and scanning electronmicrographs. Kodashana: Spring-Verlag, 1988. 198 p. 
KHUSH, G.S.; VIRMANI, S.S. Haploids in plant breeding. In: JAIN, S.M.; SOPORY, S.K.; VEILLEUX, R.E. In vitro haploid production in higher plants: fundamentals aspects and methods. New York: Kluwer Academic, 1996. v. 1, p. 11-33.

KING; R.W.; WARDTLAW, I.F.; EVANS, L.T. Effect of assimilate utilization on photosynthetic rate in wheat. Planta, Berlin, v. 77, p. 261-276, 1967.

KIRBY, E.J.M.; SPINK, J.H.; FROST, D.L.; SYLVESTER-BRADLEY, R.; SCOTT, R.K.; FOULKES, M.J.; CLARE, R.W.; EVANS, E.J. A study of wheat development in the field: analysis by phases. European Journal of Agronomy, Amsterdam, v. 11, p. 63 82, 1999.

KIRKBY, E. Introduction, definition and classification of nutrients. In: MARSCHNER'S, P. Mineral nutrition of higher plants. $3^{\text {rd }}$ ed. Washington: Academic Press, 2012. chap. 1, p. 3-5.

LABBANI, Z.; BUYSER, J.; PICARD, E. Effect of mannitol pretreatment to improve green plant regeneration on isolated microspore culture in Triticum turgidum ssp. durum cv. Jennah Khetifa. Plant Breeding, Berlin, v. 126, p. 565-568, 2007.

LABBANI, Z.; RICHARD. N.; BUYSER, J.; PICARD, E. Plants chlorophylliennes de blé dur obtenues par culture de microspores isolées: importance des prétraitements. Comptes Rendus Biologies, Paris, v. 328, p. 713-723, 2005.

LAGOS, M.B. A história do trigo no Brasil. Porto Alegre: Secretaria da Agricultura, Instituto de Pesquisas Agronômicas, Departamento de Pesquisa, 1983. 80 p. (Boletim Técnico, 10).

LARGE, E.C. Growth stages in cereals: illustration of the Feekes scale. Plant Pathology, London, v. 3, p.128-129, 1954.

LAW, C.; DEAN, C.; COUPLAND, G. Gene controlling flowering and strategies for their isolation and characterization. In: JORDAN, B.R. (Ed.). The molecular biology of flowering. Wallingford: CAB International, 1993. chap. 3, p. 47-68.

MA, H. Molecular genetic analyses of microsporogenesis and microgametogenesis in flowering plants. Annual Review Plant Biology, Palo Alto, v. 56, p. 393-434, 2005.

MALAVOLTA, E. Manual de nutrição mineral de plantas. São Paulo: Agronômica Ceres, 2006. $638 \mathrm{p}$.

MANTELL, S.H.; MATTHEWS, J.A.; McKEE, R.A. Princípios de biotecnologia em plantas: uma introdução à engenharia genética em plantas. São Bernardo do Campo: Sociedade Brasileira de Genética, 1994. 333 p.

MARASCHIN, S.F.; PRISTER, W.; SPAINK, H.P.; WANG, M. Androgenic switch: an example of plant embryogenesis from the male gametophyte perspective. Journal of Experimental Botany, Oxford, v. 56, p. 1711-1726, 2005.

MARSCHNER, H. Mineral nutrition of higher plants. $2^{\text {nd }}$ ed. London: Academic Press, 1995. $889 \mathrm{p}$. 
MARTRE, M.; JAMIESON, P. D.; SEMENOV, M. A.; ZYSKOWSKI, R. F.; PORTER, J. R. TRIBOI, E. Modelling protein content and composition in relation to crop nitrogen dynamics for wheat. European Journal of Agronomy, Amsterdam, v. 25, p.138-154, 2006.

MATSOUKAS, I.G.; MASSIAH, A.J.; THOMAS, B. Florigenic and antiflorigenic signaling in plants. Plant and Cell Physiology, Kyoto, v.53, p. 1827-1842, 2012.

McCORMICK, S. Male gametophyte development. The Plant Cell, Rockville, v. 5, p.1265$1275,1993$.

MORAES-FERNANDES, M.I.B.; PICARD, E. Viability of haploid production by anther culture using Brazilian wheat genotypes. Revista Brasileira de Genética. Ribeirão Preto, v. 6, p. 261-277, 1983.

MORAES-FERNANDES, M.I.B.; STIVAL, A.L.; BRAMMER, S.P.; GRANDO, M.F. Haplodiploidização: genética e melhoramento. In: TORRES, A.C.; CALDAS, L.S.; BUSO, J.A. (Ed.). Cultura de tecidos e transformação genética de plantas. Brasília: EMBRAPA, SPI, 1999. v. 2, p. 613-650.

MUÑOZ-AMATRIAÍN, M.; SVENSSON, J.T.; CASTILLO, A.M.; CLOSE, T.J.; VALLÉS, M.P. Microspore embryogenesis: assignment of genes to embryo formation and green vs. albino plant production. Functional and Integrative Genomics, Berlin, v. 9, p. 311-323, 2009.

NAKAMURA, A.T.; LONGHI-WAGNER, H.M.; SCATENA, V.L. Anther and pollen development in some species of Poaceae (Poales). Brazilian Journal of Biology, São Carlos, v.70, p. 351-360, 2010

OLESZCZUK, S.S.; ZIMNY, J. Androgenic response preculture stress in culture of barley. Protoplasma, Leipzig, v. 228, p. 95-100, 2006.

OSÓRIO, E.A. Trigo no Brasil. Campinas: Fundação Cargill, 1982. v. 1, 620 p.

OWEN, H.; MAKAROFF, C.A. Ultra structure of microsporogenesis and microgametogenesis in Arabidopsis thaliana (L.) Heynh: ecotype Wassilewskija (Brassicaceae). Protoplasma, Leipzig, v. 185, p. 7-21, 1995.

PATEL, M.; DARVEY, N.; MARSHALL, D.; BERRY, J.O. Optimization of culture conditions for improved plant regeneration efficiency from wheat microspore culture. Euphytica, Wageningen, v. 140, p. 197-204, 2004.

PAULS, K.P. The utility of doubled haploid propulations for studying the genetic control of traits determinated by recessive alleles. In: MOHAN JAIN, S.; SOPORY, S.K.; VEILLEUX, R.E. In vitro haploid production in higher plantas. London: Kluwer Academic, 1996. p. 125-144. (Current Plant Science and Biotechnology in Agriculture, 1).

PAULS, K.P.; CHAN, J.; WORONUK, G.; SCHULZE, D.; BRAZOLOT, J. When microspores decide to become embryos - cellular and molecular changes. Canadian Journal of Botany, Ottawa, v. 84, p. 668-678, 2006. 
PETERS, J.A.; BOBROWSKI, V.L.; ROSINHA, G.M. Produção de haploides e duplo haploides. In: TORRES, A.C.; CALDAS, L.S.; BUSO, J.A. (Ed.). Cultura de tecidos e transformação genética de plantas. Brasília: EMBRAPA, SPI, 1999. v. 2, p 569-611.

PICARD, E.; RODE, A.; DOUSSINAULT, G.; ROUSSET, M.; RIVES, M. Wheat (Triticum aestivum): in vitro production and utilization of double haploids. In: BAJAJ, Y.P.S. Haploids in crop improvement. Berlin: Spring Verlag, 1990. chap. II.1, p.101-124. (Biotechnology in Agriculture and Forestry, 12).

RAVEN, P.H.; EVERT, R.F.; EICHHORN, S.E. Biologia vegetal. Trad. de J.E. Kraus. 7 ed. Rio de Janeiro: Guanabara Koogan, 2010. 830 p.

REID, R.J. Kinetics of nutrient uptake by plant cells. In: RENGEL, Z. (Ed.). Mineral nutrition of crops. New York: Food Products Press. 1999. chap. 2, p. 41-66.

REKASEM, B.; JAMJOD, S. Boron deficiency induced male sterility in wheat (Triticum aestivum L.) and implications for plant breeding. Euphytica, Wageningen, v. 96, p. 257-262, 1997.

REYNOLDS, T.L. Pollen embryogenesis. Plant Molecular Biology, Dordrecht, v. 33, p. 110, 1997.

RISSINI, A.L.L. NDVI, Crescimento e produtividade de cultivares de trigo submetidas a doses de nitrogênio. 2011. 53 p. Dissertação (Mestrado em Produção Vegetal) - Universidade Estadual do Centro-Oeste, Guarapuava, 2011.

RODRIGUES, O.; TEIXEIRA, M.C.C.; COSTENARO, E.R.; SANA, D. Ecofisiologia de trigo: bases para elevado rendimento de grãos. In: PIRES, J.; VARGAS, L.; CUNHA, G.R. Trigo no Brasil: bases da produção competitiva e sustentável. Passo Fundo: Embrapa Trigo, 2011. cap. 5, p. 115-132.

SARRUGE, J.R. Soluções nutritivas. Summa Phytopathologica, Botucatu, v. 1, p. 231-233, 1975.

SCHEEREN, P.L. Instruções para utilização de descritores de trigo (Triticum ssp.) e Triticale (Triticosecale sp.) Passo Fundo: EMBRAPA-CNPT, 1984. Documentos n. 09, 32p.

SCHEEREN, P.L.; CAIERÃO, E.; SÓ E SILVA, M.; BONOW, S. Melhoramento de trigo no Brasil. In: PIRES, J.; VARGAS, L.; CUNHA, G.R. Trigo no Brasil; bases da produção competitiva e sustentável. Passo Fundo: Embrapa Trigo, 2011. cap. 17, p. 427-452.

SCOTT, R. Anther development: a molecular perspective. In: JORDAN, B.R. The molecular biology flowering. Wallingford: CAB International, 1994. chap. 7, p. 141-184.

SHIVANNA, K.R. Pollen biology and biotechnology. Enfield: Science Publ., 2003. 301 p.

SINCLAIR, T.R.; JAMIESON, P.D. Grain number, wheat yield, and bottling beer: an analysis. Field Crop Research, Amsterdam, v. 98, p. 60-70, 2006.

ŚLUSARKIEWICZ-JARZINA, A.; PONITKA, A. The effect of physical medium state on anther culture response in polish cultivated oat (Avena sativa L.) Acta Biologica Cracoviensia, Series Botanica, Krakow, v. 49, p. 27-31, 2007. 
SMITH, F.W. Molecular biology of nutrients transporters in plant membranes. In: RENGEL, Z. (Ed.). Mineral nutrition of crops. New York: Food Products Press. 1999. chap. 3, p. 6789.

SMYKÁL, P. Pollen embryogenesis: the stress mediated switch from gametophytic to sporophytic development. Current status and future prospects. Biologia Plantarum, Praga, v. 43, p. 481-489, 2000.

SOUZA, C.N.A. de. Relação das cultivares comerciais de trigo no Brasil de 1922 a 1997. Passo Fundo: EMBRAPA, CNPT, 1997. 46 p.

STREET, H.E.; ÖPIK, E. The flowering plants: their growth and development. $3^{\text {rd }}$ ed. Scotland: Cotemporary Biology, 1984. 279 p.

TAIZ, L.; ZEIGER, E. Plant physiology. $5^{\text {th }}$ ed. Sunderland: Sinauer Associates, 2010. 782 p.

TENHOLA-ROININEN, T.; ANHUANPÄÄ, P.; IMMONEN, S. The effect of cold and heat treatments on the anther culture response of diverse rye genotypes. Euphytica, Wageningen, v. 145 , p. 1-9, 2005.

TOURAEV, A.; PFOSSER, M.; HEBERLE-BORS, E. The microspore: a haploid multipurpose cell. Advances in Botanical Research, London, v. 35, p. 53-109, 2001.

TREMBLAY, R.; COLASANTI, J. Floral induction. Annual Review of Plant, Oxford, v. 20, p. 28-46, 2006.

TSAY, H.S. Effects of nitrogen supply to donor plants on pollen embryogenesis in cultured tobacco anthers. Journal of Agricultural Research of China, Nanning, v. 30, p. 5-13, 1981.

WELLBURN, A.R. The spectral determination of chlorophylls $a$ and $b$, as well as total carotenoids, using various solvents with spectrophotometers of different resolution. Journal of Plant Physiology, Stuttgart, v. 144, p. 307-313, 1994.

WHEATLEY, W.G.; MARSOLAIS, A.A.; KASHA, K.J. Microspore growth and anther staging in barley anther culture. Plant Cell Reports. Berlin, v. 5, p. 47-49, 1986.

WIESLER, F. Nutrition and quality. In: MARSCHNER'S, P. Mineral nutrition of higher plants. $3^{\text {rd }}$ ed. Washington: Academic Press, 2012. chap. 9, p. 271-282.

WIETHÖLTER, S. Fertilidade do solo e a cultura do trigo no Brasil. In: PIRES, J.; VARGAS, L.; CUNHA, G.R. (Ed.). Trigo no Brasil: bases da produção competitiva e sustentável. Passo Fundo: Embrapa Trigo, 2011. cap. 6, p. 135-184.

WONGMO, J.; JAMJOD, S.; RERKASEM, B. Contrasting responses to boron deficiency in barley and wheat. Plant and Soil, Amsterdam, v. 259, p. 103-110, 2004.

ZADOKS, J.C.; CHANG, T.T.; KONZAK, C.F. A decimal code for the growth stages of cereals. Weed Research, Oxford, v. 14, p. 415-421, 1974.

ZAKI, M.A.; DICKINSON, H.G. Gene expression during microsporogenesis. In: CRESTI, M.; TIEZZI, A. Sexual plant reproduction. Berlin: Spring-Verlag, 1992. p. 17-29. 
ZHANG, D.; LUO, X.; ZHU, L. Cytological analysis and genetic control of rice anther development. Journal of Genetics and Genomics, Amsterdam, v. 38, p. 379-390, 2011.

ZHENG, M.Y. Microspore culture in wheat (Triticum aestivum L.): doubled haploid production via induced embryogenesis. Plant Cell, Tissue and Organ Culture; Dordrecht, v. 73, p. 213-230, 2003. 
APÊNDICES 
Apêndice A - Composição da solução de Sarruge (1975) original utilizada como padrão para o experimento e as soluções modificadas com as cinco concentrações de nitrogênio $25 \%, 50 \%, 100 \%, 150 \%$ e $200 \%$ e com a concentração de potássio balanceada utilizadas no experimento

\begin{tabular}{|c|c|c|c|c|c|c|}
\hline & Original & $\mathrm{N} 25$ & N50 & N100 & N150 & $\mathrm{N} 200$ \\
\hline \multicolumn{7}{|c|}{ Macronutrientes $\left(\mu \mathrm{mol} \mathrm{L}{ }^{-1}\right)$ : } \\
\hline $\mathrm{KH}_{2} \mathrm{PO}_{4}$ & 1.000 & 1.000 & 1.000 & 1.000 & 1.000 & 1.000 \\
\hline $\mathrm{KNO}_{3}$ & 5.000 & 1.250 & 2.500 & 5.000 & 7.500 & 10.000 \\
\hline $\mathrm{MgSO}_{4} \cdot 7 \mathrm{H}_{2} \mathrm{O}$ & 2.000 & 2.000 & 2.000 & 2.000 & 2.000 & 2.000 \\
\hline $\mathrm{CaCl}_{2} \cdot 2 \mathrm{H}_{2} \mathrm{O}$ & 5.000 & 5.000 & 5.000 & 5.000 & 5.000 & 5.000 \\
\hline $\mathrm{NH}_{4} \mathrm{NO}_{3}$ & 5.000 & 12.500 & 2.500 & 5.000 & 7.500 & 10.000 \\
\hline $\mathrm{KCl}$ & 0 & $1.750^{*}$ & $1.500^{*}$ & $1.000^{*}$ & $500^{*}$ & $0^{*}$ \\
\hline \multicolumn{7}{|c|}{ Micronutrientes $\left(\mu \mathrm{mol} \mathrm{L}^{-1}\right)$ : } \\
\hline $\mathrm{H}_{3} \mathrm{BO}_{3}$ & 46,26 & 46,26 & 46,26 & 46,26 & 46,26 & 46,26 \\
\hline $\mathrm{MnCl}_{2} .4 \mathrm{H}_{2} \mathrm{O}$ & 9,15 & 9,15 & 9,15 & 9,15 & 9,15 & 9,15 \\
\hline $\mathrm{ZnCl}_{2}$ & 0,73 & 0,73 & 0,73 & 0,73 & 0,73 & 0,73 \\
\hline $\mathrm{CuCl}_{2}$ & 0,16 & 0,16 & 0,16 & 0,16 & 0,16 & 0,16 \\
\hline $\mathrm{MoNa}_{2} \mathrm{O} 4.2 \mathrm{H}_{2} \mathrm{O}$ & 0,08 & 0,08 & 0,08 & 0,08 & 0,08 & 0,08 \\
\hline \multicolumn{7}{|c|}{ FeEDTA $\left(\mu \mathrm{mol} \mathrm{L}^{-1}\right)$} \\
\hline $\mathrm{FeSO}_{4} .7 \mathrm{H}_{2} \mathrm{O}$ & 99,99 & 99,99 & 99,99 & 99,99 & 99,99 & 99,99 \\
\hline EDTA & 100,74 & 100,74 & 100,74 & 100,74 & 100,74 & 100,74 \\
\hline
\end{tabular}

* Valores utilizados para ajustar a concentração de potássio nas soluções devido ao aumento da concentração de $\mathrm{KNO}_{3}$. 
Apêndice B - Composição da solução de Sarruge (1975) original utilizada como padrão para o experimento e as soluções modificadas com as cinco concentrações de boro $25 \%, 50 \%, 100 \%, 150 \%$ e $200 \%$

\begin{tabular}{|c|c|c|c|c|c|c|}
\hline & Original & $\mathrm{B} 25$ & $\mathrm{~B} 50$ & $\mathrm{~B} 100$ & $\mathrm{~B} 150$ & B200 \\
\hline \multicolumn{7}{|c|}{ Macronutrientes $\left(\mu \mathrm{mol} \mathrm{L}^{-1}\right)$ : } \\
\hline $\mathrm{KH}_{2} \mathrm{PO}_{4}$ & 1.000 & 1.000 & 1.000 & 1.000 & 1.000 & 1.000 \\
\hline $\mathrm{KNO}_{3}$ & 5.000 & 5.000 & 5.000 & 5.000 & 5.000 & 5.000 \\
\hline $\mathrm{MgSO}_{4} .7 \mathrm{H}_{2} \mathrm{O}$ & 2.000 & 2.000 & 2.000 & 2.000 & 2.000 & 2.000 \\
\hline $\mathrm{CaCl}_{2} \cdot 2 \mathrm{H}_{2} \mathrm{O}$ & 5.000 & 5.000 & 5.000 & 5.000 & 5.000 & 5.000 \\
\hline $\mathrm{NH}_{4} \mathrm{NO}_{3}$ & 5.000 & 5.000 & 5.000 & 5.000 & 5.000 & 5.000 \\
\hline $\mathrm{KCl}$ & 0 & 0 & 0 & 0 & 0 & 0 \\
\hline \multicolumn{7}{|c|}{ Micronutrientes $\left(\mu \mathrm{mol} \mathrm{L}^{-1}\right)$ : } \\
\hline $\mathrm{H}_{3} \mathrm{BO}_{3}$ & 46,26 & 11,56 & 23,13 & 46,26 & 69,38 & 92,51 \\
\hline $\mathrm{MnCl}_{2} \cdot 4 \mathrm{H}_{2} \mathrm{O}$ & 9,15 & 9,15 & 9,15 & 9,15 & 9,15 & 9,15 \\
\hline $\mathrm{ZnCl}_{2}$ & 0,73 & 0,73 & 0,73 & 0,73 & 0,73 & 0,73 \\
\hline $\mathrm{CuCl}_{2}$ & 0,16 & 0,16 & 0,16 & 0,16 & 0,16 & 0,16 \\
\hline $\mathrm{MoNa}_{2} \mathrm{O}_{4} \cdot 2 \mathrm{H}_{2} \mathrm{O}$ & 0,08 & 0,08 & 0,08 & 0,08 & 0,08 & 0,08 \\
\hline \multicolumn{7}{|c|}{ FeEDTA $\left(\mu \mathrm{mol} \mathrm{L}^{-1}\right)$} \\
\hline $\mathrm{FeSO}_{4 .} .7 \mathrm{H}_{2} \mathrm{O}$ & 99,99 & 99,99 & 99,99 & 99,99 & 99,99 & 99,99 \\
\hline EDTA & 100,74 & 100,74 & 100,74 & 100,74 & 100,74 & 100,74 \\
\hline
\end{tabular}


Apêndice C - Composição do meio de cultura batata II modificado e o meio descrito por Moraes-Fernandes \& Picard (1983)

\begin{tabular}{|c|c|c|}
\hline & Indução & Regeneração \\
\hline Extrato de batata* & $100 \mathrm{~g}$ & - \\
\hline \multicolumn{3}{|c|}{ MACRONUTRIENTES $\left(\mathrm{mg} \mathrm{L}^{-1}\right)$} \\
\hline $\mathrm{KNO}_{3}$ & 1000 & 1000 \\
\hline $\mathrm{KH}_{2} \mathrm{PO}_{4}$ & 200 & 300 \\
\hline$\left(\mathrm{NH}_{4}\right)_{2} \mathrm{SO}_{4}$ & 100 & - \\
\hline $\mathrm{NH}_{4} \mathrm{NO}_{3}$ & - & 1000 \\
\hline $\mathrm{Ca}\left(\mathrm{NO}_{3}\right)_{2} \cdot 4 \mathrm{H}_{2} \mathrm{O}$ & 100 & 500 \\
\hline $\mathrm{MgSO}_{4} .7 \mathrm{H}_{2} \mathrm{O}$ & 125 & 71,5 \\
\hline $\mathrm{KCl}$ & 35 & 65 \\
\hline \multicolumn{3}{|c|}{ MACRONUTRIENTES $\left(\mathrm{mg} \mathrm{L}^{-1}\right)$} \\
\hline $\mathrm{MnSO}_{4} \cdot \mathrm{H}_{2} \mathrm{O}$ & - & 490 \\
\hline $\mathrm{ZnSO}_{4} 7 \mathrm{H}_{2} \mathrm{O}$ & - & 270 \\
\hline $\mathrm{H}_{3} \mathrm{BO}_{3}$ & - & 160 \\
\hline KI & - & 75 \\
\hline \multicolumn{3}{|c|}{ VITAMINAS $\left(\mathrm{mg} \mathrm{L}^{-1}\right)$} \\
\hline Ácido nicotínico & 5 & 5 \\
\hline Pirioxina $\mathrm{HCl}$ & 5 & 5 \\
\hline Tiamina $\mathrm{HCl}$ & 6 & 1 \\
\hline Inositol & 100 & 100 \\
\hline Glicina & 2 & 2 \\
\hline Kinetina & 0,5 & - \\
\hline $2,4-\mathrm{D}$ & 2 & - \\
\hline ANA & - & 1 \\
\hline Sacarose & $100 \mathrm{~g}$ & $30 \mathrm{~g}$ \\
\hline Ágar & $9 \mathrm{~g}$ & $8 g$ \\
\hline $\mathrm{FeSO}_{4} .7 \mathrm{H}_{2} \mathrm{O}$ & $27,8 \mathrm{~g}$ & $27,8 \mathrm{~g}$ \\
\hline EDTA & $37,3 \mathrm{~g}$ & $37,3 \mathrm{~g}$ \\
\hline
\end{tabular}

* Para o extrato de batata pesar $250 \mathrm{~g}$ de batata inglesa descascada e cortada em pequenos cubos e adicionar $1.250 \mathrm{ml}$ de água destilada. Colocar para ferver e, após iniciar a fervura, marcar 30 minutos. Decorrido esse tempo, coar e reservar o líquido por 12 horas em geladeira. Utilizar $100 \mathrm{ml}$ do sobrenadante para um litro de meio. 